\title{
Russian Research Capabilities: Findings of Site Visits
}

D. W. Wester

February 1994

Prepared for the U.S. Department of Energy under Contract DE-AC06-76RLO 1830

Pacific Northwest Laboratory

Operated for the U.S. Department of Energy by Battelle Memorial Institute 


\title{
DISCLAIMER
}

This report was prepared as an account of work sponsored by an agency of the United States Government. Neither the United States Government nor any agency thereof, nor Battelle Memorial Institute, nor any of their employees, makes any warranty, expressed or implied, or assumes any legal liability or responsibility for the accuracy, completeness, or usefulness of any information, apparatus, product, or process disclosed, or represents that its use would not infringe privately owned rights. Reference herein to any specific commercial product, process, or service by trade name, trademark, manufacturer, or otherwise does not necessarily constitute or imply its endorsement, recommendation, or favoring by the United States Government or any agency thereof, or Battelle Memorial Institute. The views and opinions of authors expressed herein do not necessarily state or reflect those of the United States Government or any agency thereof.

\author{
PACIFIC NORTHWEST LABORATORY \\ operated by \\ BATTELLE MEMORIAL INSTITUTE \\ for the \\ UNITED STATES DEPARTMENT OF ENERGY \\ under Contract DE-ACO6-76RLO 1830
}

Printed in the United States of America

\begin{abstract}
Available to DOE and DOE contractors from the
Office of Scientific and Technical Information, P.O. Box 62, Oak Ridge, TN 37831;

prices available from (615) 576-8401. FTS 626-8401.
\end{abstract}

Available to the public from the National Technical Information Service, U.S. Department of Commerce, 5285 Port Royal Rd., Springfield, VA 22161. 
PNL-9024

UC-600

\section{Russian Research Capabilities: Findings of Site Visits}

D. W. Wester

February 1994

Prepared for International Environmental Institute and the U.S. Department of Energy under Contract DE-AC06-76RLO 1830

Pacific Northwest Laboratory Richland, Washington 99352 
1 


\section{Summary}

Institutes and universities of the former Soviet Union that are located in Novosibirsk, St. Petersburg, and Moscow were visited to evaluate their capabilities for carrying out joint research with American partners. The quality and spirit of the scientists was very high, though the condition of the laboratories and infrastructure was quite poor. 



\title{
Glossary
}

\author{
APC \\ Applied Physics Center \\ DOE \\ U.S. Department of Energy \\ EESC \\ Earth and Environmental Sciences Center, Pacific Northwest \\ Laboratory \\ EPR \\ electronic paramagnetic resonance \\ ESPIP \\ Efficient Separations and Processing Integrated Program \\ ETC \\ Engineering Technology Center, Pacific Northwest Laboratory \\ EXAFS \\ $\mathrm{x}$-ray absorption fine structure \\ FFTF \\ Fast Flux Test Facility \\ GC-MS \\ gas chromatography-mass spectrometry \\ HLW \\ high-level waste \\ IC \\ Institute of Catalysis \\ ICG \\ Institute of Cytology and Genetics \\ ICMR-S \\ International Centre for Materials Research, Siberia \\ IEI \\ International Environmental Institute \\ IIC \\ Institute of Inorganic Chemistry \\ IGG \\ Institute of Geology and Geophysics \\ IM \\ Institute of Mathematics \\ IOC \\ Institute of Organic Chemistry \\ IOEC \\ Institute of Organoelement Compounds \\ IPC \\ Institute of Physical Chemistry \\ IR \\ infrared \\ ITP \\ Institute of Thermal Physics \\ IUPAC \\ International Union of Pure and Applied Chemistry
}


LDRD

LSC

MSRC

MCSC

NIST

NMR

PUREX

PNL

RAS

SABIT

SAIC

TAA

TWRS

UAI

UV

VOC-ID

WHC

XPS laboratory-directed research and development

Life Sciences Center, Pacific Northwest Laboratory

Molecular Science Research Center, Pacific Northwest Laboratory

Materials and Chemical Sciences Center, Pacific Northwest Laboratory

National Institute for Standards and Technology

nuclear magnetic resonance

plutonium uranium extraction

Pacific Northwest Laboratory

Russian Academy of Sciences

Special American Business Internship Training

Science Applications International Corporation

tetraalkylammonium

Tank Waste Remediation System

Ufimskii Aviation Institute

ultraviolet

Volatile Organic Carbon-Integrated Demonstration

Westinghouse Hanford Company

x-ray photoelectron spectroscopy 


\section{Contents}

Summary $\ldots \ldots \ldots \ldots \ldots \ldots \ldots \ldots \ldots \ldots \ldots \ldots \ldots \ldots \ldots$ iii

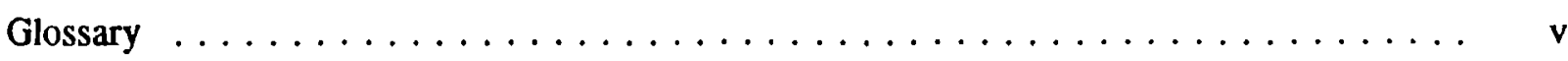

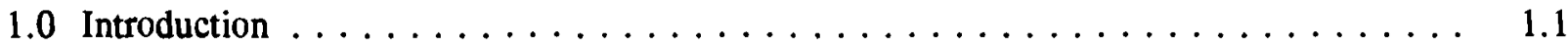

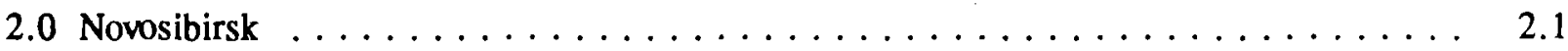

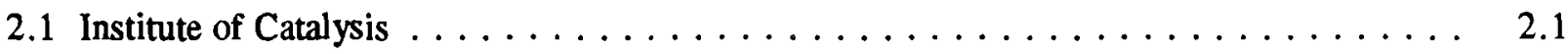

2.1 .1 General Description $\ldots \ldots \ldots \ldots \ldots \ldots \ldots \ldots \ldots \ldots \ldots \ldots \ldots \ldots$

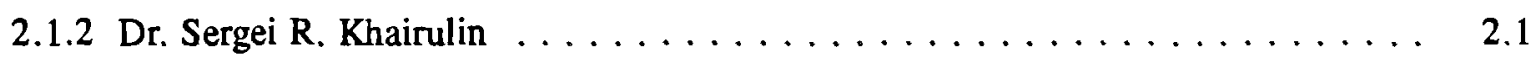

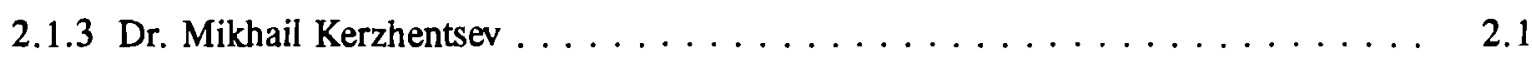

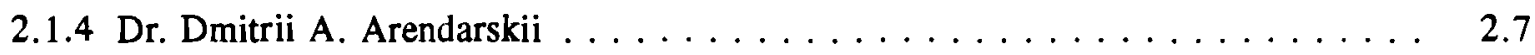

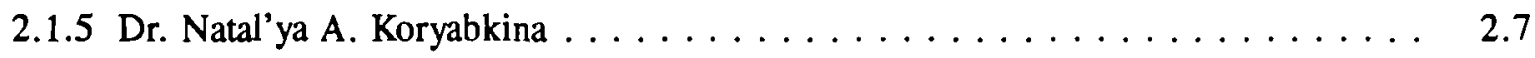

2.1.6 Dr. Andrei V. Simakov and Dr. Aleksandr A. Kirchanov . . . . . . . . . . 2.7

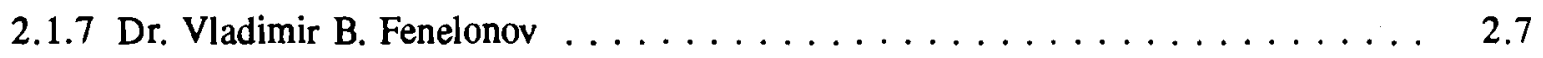

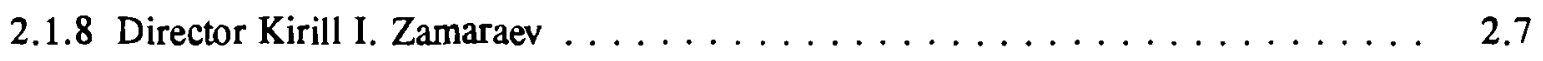

2.1 .9 Assessment $\ldots \ldots \ldots \ldots \ldots \ldots \ldots \ldots \ldots \ldots \ldots \ldots \ldots \ldots \ldots$

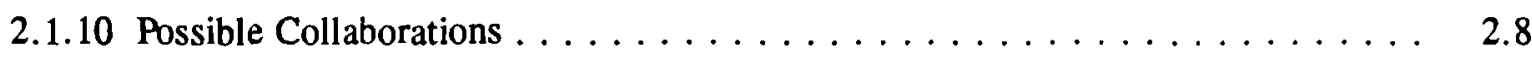

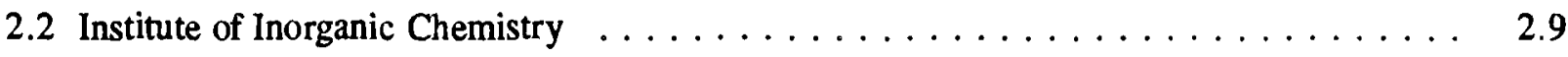

2.2 .1 General Description $\ldots \ldots \ldots \ldots \ldots \ldots \ldots \ldots \ldots \ldots \ldots \ldots$

2.2.2 Dr. Vladimir V. Volkov $\ldots \ldots \ldots \ldots \ldots \ldots \ldots \ldots \ldots \ldots \ldots \ldots$

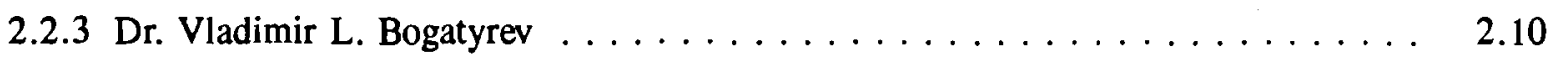

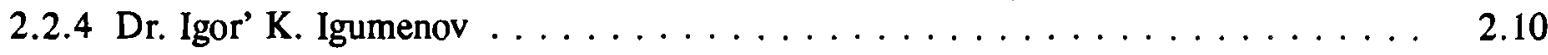

2.2 .5 Dr. Lev N. Mazalov $\ldots \ldots \ldots \ldots \ldots \ldots \ldots \ldots \ldots \ldots \ldots \ldots \ldots \ldots$

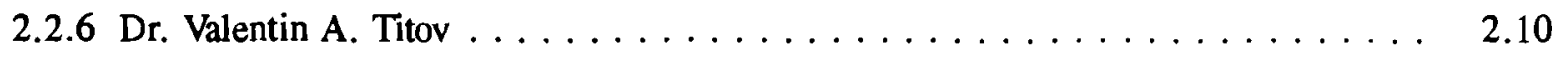

2.2.7 Dr. Yan V. Vasil'ev and Dr. Anatolii A. Pavlyuk $\ldots \ldots \ldots \ldots \ldots \ldots \ldots$ 


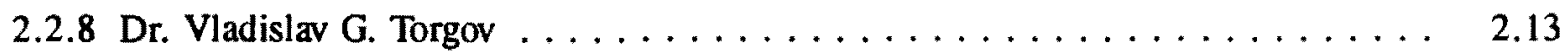

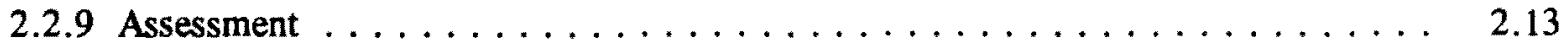

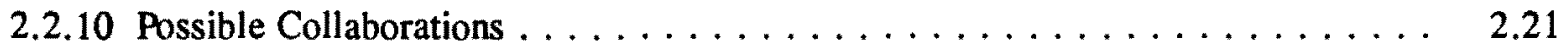

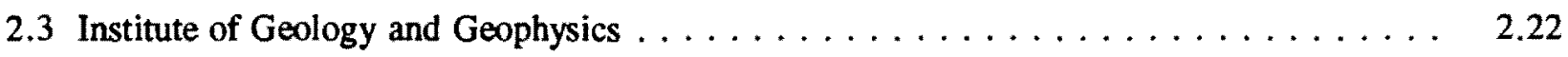

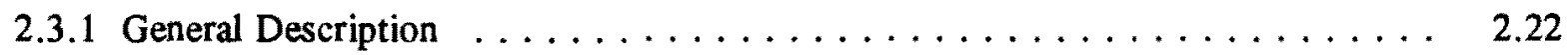

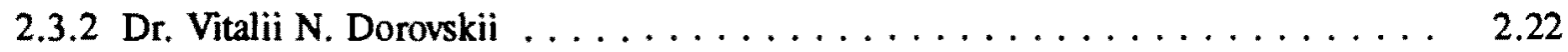

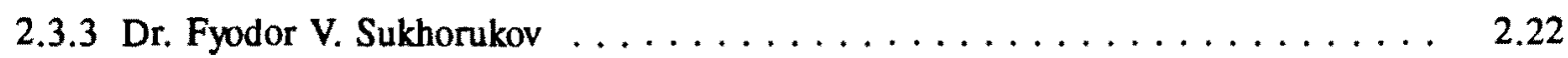

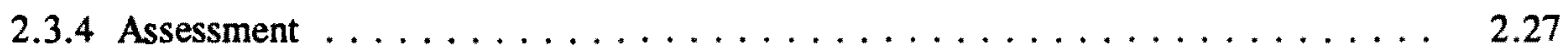

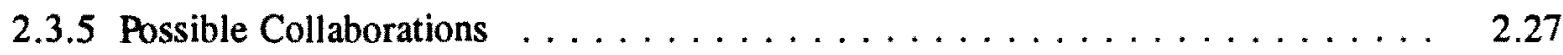

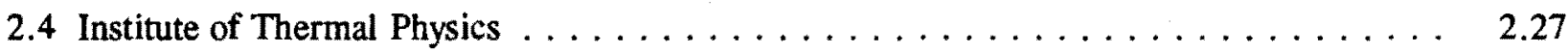

2.4.1 General Description $\ldots \ldots \ldots \ldots \ldots \ldots \ldots \ldots \ldots \ldots \ldots \ldots \ldots \ldots$

2.4.2 Dr. Sergei V. Stankus $\ldots \ldots \ldots \ldots \ldots \ldots \ldots \ldots \ldots \ldots \ldots \ldots \ldots$

2.4 .3 Assessment $\ldots \ldots \ldots \ldots \ldots \ldots \ldots \ldots \ldots \ldots \ldots \ldots \ldots \ldots \ldots \ldots \ldots$

2.4.4 Possible Collaborations $\ldots \ldots \ldots \ldots \ldots \ldots \ldots \ldots \ldots \ldots \ldots \ldots$

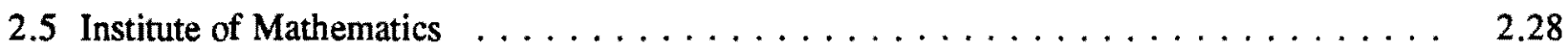

2.5.1 Dr. Aleksandr M. Blokhin $\ldots \ldots \ldots \ldots \ldots \ldots \ldots \ldots \ldots \ldots \ldots \ldots$

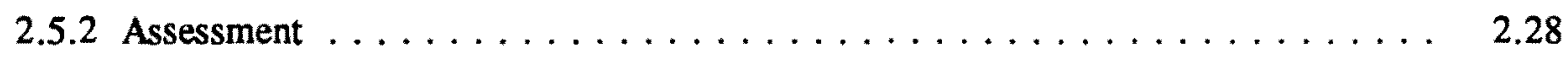

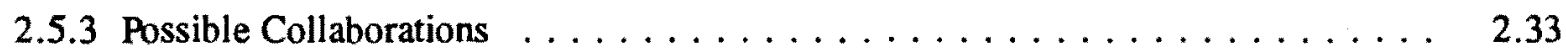

2.6 Siberian Branch All-Russian Scientific-Research Planning Institute of Energy

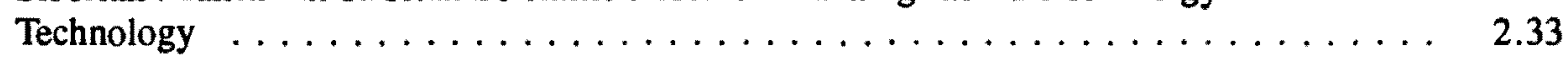

2.6.1 General Description $\ldots \ldots \ldots \ldots \ldots \ldots \ldots \ldots \ldots \ldots \ldots \ldots \ldots$

2.6.2 Drs. Yurii V. Ostrovskii, Boris I. Lunyushkin, and Sergei M. Boboedov . . . . 2.33

2.6.3 Possible Collaborations $\ldots \ldots \ldots \ldots \ldots \ldots \ldots \ldots \ldots \ldots \ldots \ldots \ldots$

2.7 Institute of Cytology and Genetics $\ldots \ldots \ldots \ldots \ldots \ldots \ldots \ldots \ldots \ldots$

2.7 .1 General Description $\ldots \ldots \ldots \ldots \ldots \ldots \ldots \ldots \ldots \ldots \ldots \ldots \ldots \ldots$

viii 


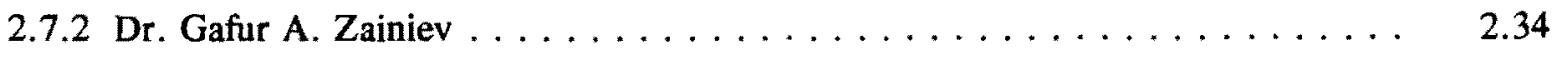

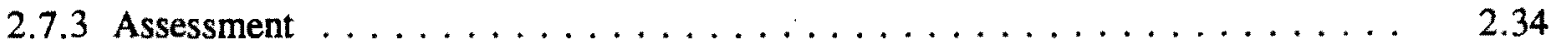

2.7.4 Possible Collaborations . . . . . . . . . . . . . . . . . . 2.34

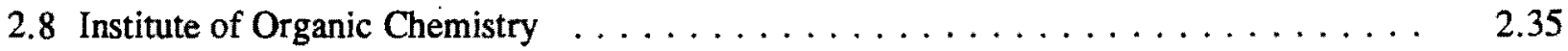

2.8.1 General Description $\ldots \ldots \ldots \ldots \ldots \ldots \ldots \ldots \ldots \ldots \ldots \ldots \ldots$

2.8.2 Dr. Boris G. Derendyaev $\ldots \ldots \ldots \ldots \ldots \ldots \ldots \ldots \ldots \ldots \ldots \ldots \ldots \ldots \ldots \ldots$

2.8.3 Associate Professor Victor M. Tormyshev $\ldots \ldots \ldots \ldots \ldots \ldots \ldots .2 .35$

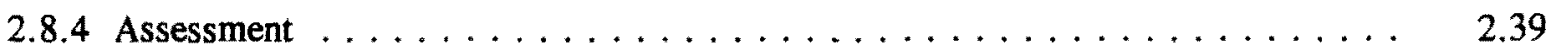

2.8 .5 Possible Collaborations . . . . . . . . . . . . . . . . . . . . . . . . . 2.39

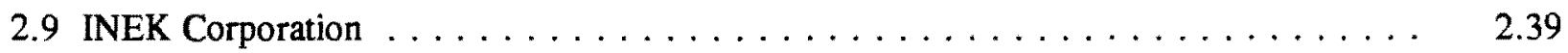

2.9 .1 General Description . . . . . . . . . . . . . . . . . . . . 2.39

2.9 .2 Dr. Igor' T. Ovchinnikov $\ldots \ldots \ldots \ldots \ldots \ldots \ldots \ldots \ldots \ldots \ldots .2 .39$

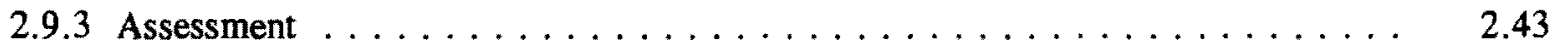

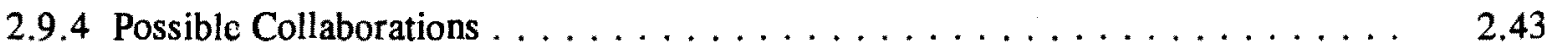

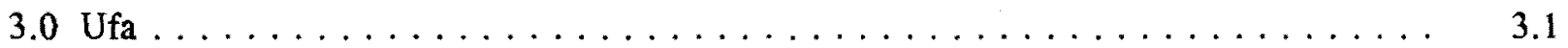

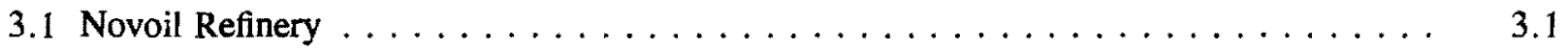

3.1 .1 General Description $\ldots \ldots \ldots \ldots \ldots \ldots \ldots \ldots \ldots \ldots \ldots, 3.1$

3.1 .2 Assessment $\ldots \ldots \ldots \ldots \ldots \ldots \ldots \ldots \ldots \ldots \ldots \ldots \ldots \ldots, 3.1$

3.1 .3 Possible Collaborations $\ldots \ldots \ldots \ldots \ldots \ldots \ldots \ldots \ldots \ldots \ldots \ldots . .1$

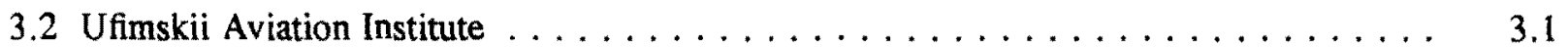

3.2.1 General Description . . . . . . . . . . . . . . . . . . . . . . . . 3.1

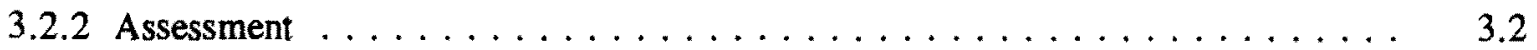

3.2 .3 Possible Collaborations . . . . . . . . . . . . . . . . . . . . 3.2

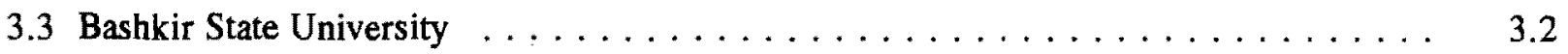

3.3 .1 General Description $\ldots \ldots \ldots \ldots \ldots \ldots \ldots \ldots \ldots \ldots \ldots \ldots .2$ 
3.3.2 Dr. Florida K. Kudasheva . . . . . . . . . . . . . . 3.2

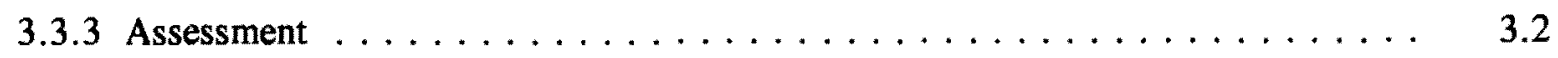

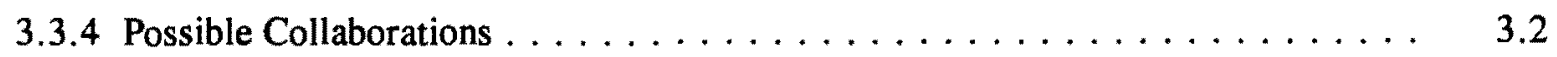

4.0 Kemerovo $\ldots \ldots \ldots \ldots \ldots \ldots \ldots \ldots \ldots \ldots \ldots \ldots \ldots \ldots \ldots$

4.1 TOKEM Company $\ldots \ldots \ldots \ldots \ldots \ldots \ldots \ldots \ldots \ldots \ldots \ldots \ldots$

4.1 .1 General Description $\ldots \ldots \ldots \ldots \ldots \ldots \ldots \ldots \ldots \ldots \ldots \ldots \ldots$

4.1 .2 Assessment $\ldots \ldots \ldots \ldots \ldots \ldots \ldots \ldots \ldots \ldots \ldots \ldots \ldots \ldots$

4.1 .3 Possible Collaborations . . . . . . . . . . . . . . . . . 4.1

4.2 Kemerovo State University $\ldots \ldots \ldots \ldots \ldots \ldots \ldots \ldots \ldots \ldots \ldots \ldots$

4.2 .1 General Description $\ldots \ldots \ldots \ldots \ldots \ldots \ldots \ldots \ldots \ldots \ldots \ldots \ldots$

4.2 .2 Professor Sergei M. Ryabyk . . . . . . . . . . . . . 4.2

4.2 .3 Possible Collaborations . . . . . . . . . . . . $4 \ldots \ldots$

4.3 Institute of Coal, Siberian Division of the RAS $\ldots \ldots \ldots \ldots \ldots \ldots$

43.1 General Description $\ldots \ldots \ldots \ldots \ldots \ldots \ldots \ldots \ldots \ldots \ldots \ldots$

4.3.2 Gennadii I. Gritsko, Aleksandr B. Logov, et al. . . . . . . . . . . . 4.2

4.3 .3 Assessment $\ldots \ldots \ldots \ldots \ldots \ldots \ldots \ldots \ldots \ldots \ldots \ldots \ldots \ldots$

4.3 .4 Possible Collaborations $\ldots \ldots \ldots \ldots \ldots \ldots \ldots \ldots \ldots \ldots \ldots$

5.0 Ulan Ude $\ldots \ldots \ldots \ldots \ldots \ldots \ldots \ldots \ldots \ldots \ldots \ldots \ldots \ldots \ldots \ldots$

5.1 Geological Institute, Buryat Branch, Siberian Division of the RAS . . . . . . . 5.1

5.1 .1 Dr. Alexander L. Kovalevskii $\ldots \ldots \ldots \ldots \ldots \ldots \ldots \ldots \ldots \ldots \ldots \ldots \ldots \ldots \ldots$

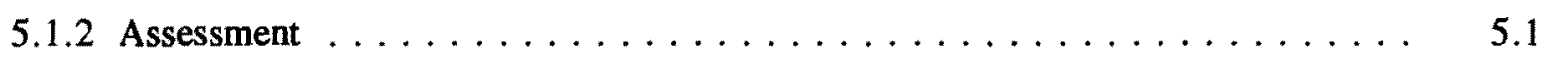

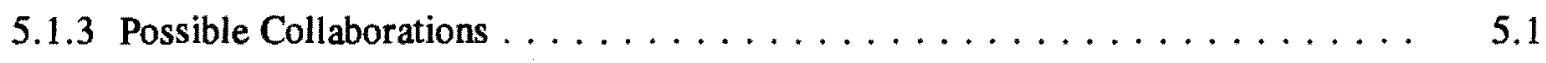

6.0 St. Petersburg $\ldots \ldots \ldots \ldots \ldots \ldots \ldots \ldots \ldots \ldots \ldots \ldots \ldots \ldots \ldots \ldots$

6.1 St. Petersburg State University $\ldots \ldots \ldots \ldots \ldots \ldots \ldots \ldots \ldots \ldots \ldots \ldots$

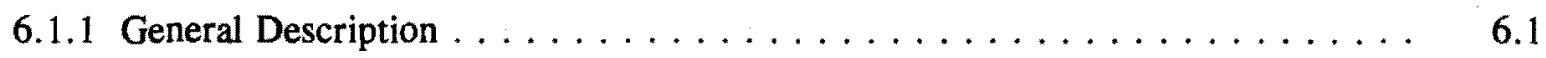


6.2 Department of Chemistry $\ldots \ldots \ldots \ldots \ldots \ldots \ldots \ldots \ldots \ldots \ldots \ldots \ldots$

6.2 .1 Dr. Alexei Yu. Ershov $\ldots \ldots \ldots \ldots \ldots \ldots \ldots \ldots \ldots \ldots \ldots \ldots$

6.2 .2 Assessment $\ldots \ldots \ldots \ldots \ldots \ldots \ldots \ldots \ldots \ldots \ldots \ldots \ldots \ldots \ldots$

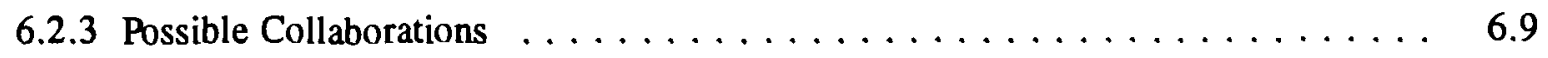

6.3 Department of Radiochemistry $\ldots \ldots \ldots \ldots \ldots \ldots \ldots \ldots \ldots$

6.3.1 General Description $\ldots \ldots \ldots \ldots \ldots \ldots \ldots \ldots \ldots \ldots \ldots \ldots \ldots \ldots \ldots$

6.3 .2 Dr. Yurii F. Batryakov $\ldots \ldots \ldots \ldots \ldots \ldots \ldots \ldots \ldots \ldots \ldots \ldots$

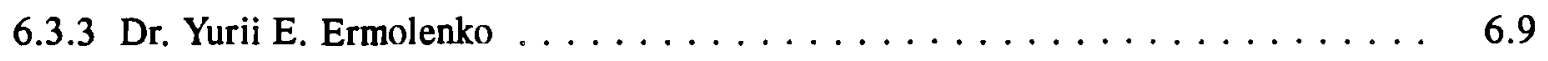

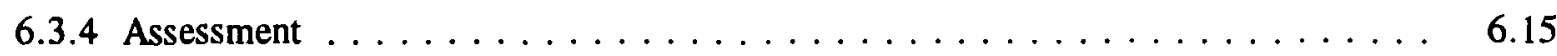

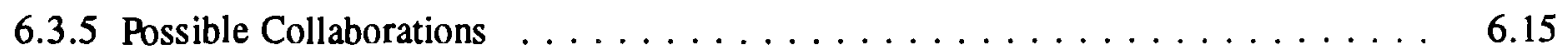

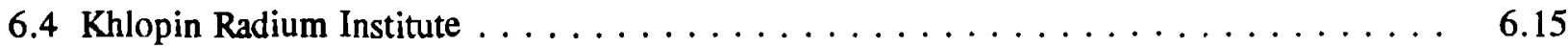

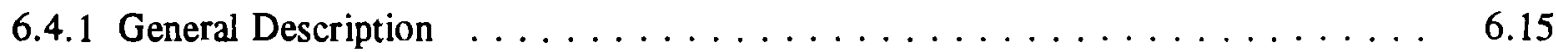

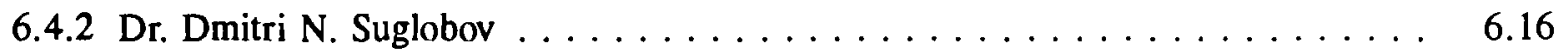

6.4 .3 Assessment $\ldots \ldots \ldots \ldots \ldots \ldots \ldots \ldots \ldots \ldots \ldots \ldots \ldots \ldots$

6.4 .4 Possible Collaborations $\ldots \ldots \ldots \ldots \ldots \ldots \ldots \ldots \ldots \ldots \ldots \ldots$

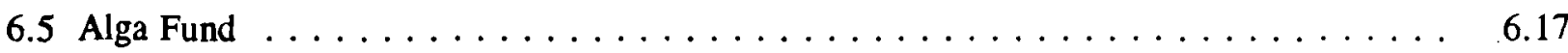

6.5 .1 General Description $\ldots \ldots \ldots \ldots \ldots \ldots \ldots \ldots \ldots \ldots$

6.5 .2 Dr. Valerii A. Isidorov . . . . . . . . . . . . . . . 6.17

6.5 .3 Assessment $\ldots \ldots \ldots \ldots \ldots \ldots \ldots \ldots \ldots \ldots \ldots \ldots \ldots$

6.5 .4 Possible Collaborations $\ldots \ldots \ldots \ldots \ldots \ldots \ldots \ldots \ldots \ldots \ldots \ldots$

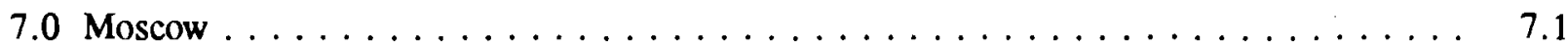

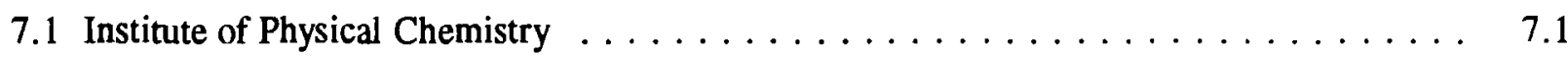

7.1 .1 General Description $\ldots \ldots \ldots \ldots \ldots \ldots \ldots \ldots \ldots \ldots \ldots \ldots$

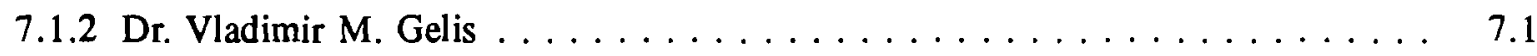

7.1.3 Dr. Vyacheslav I. Kareta . . . . . . . . . . . . . . . . 7.1 
7.1.4 Dr. Elena V. Zakharova $\ldots \ldots \ldots \ldots \ldots \ldots \ldots \ldots \ldots \ldots \ldots \ldots \ldots \ldots \ldots$

7.1 .5 Mr. Yurii $S$. Pavlov $\ldots \ldots \ldots \ldots \ldots \ldots \ldots \ldots \ldots \ldots \ldots \ldots \ldots \ldots \ldots \ldots \ldots \ldots$

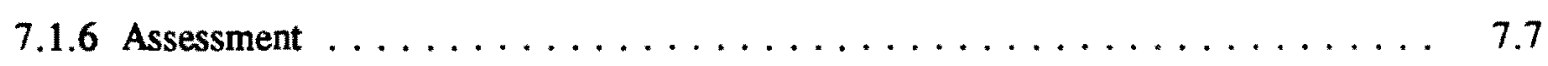

7.1.7 Possible Collaborations $\ldots \ldots \ldots \ldots \ldots \ldots \ldots \ldots \ldots \ldots \ldots \ldots \ldots \ldots \ldots .13$

7.2 All-Russian Scientific-Research Institute of Chemical Technology $\ldots \ldots \ldots \ldots \ldots 7.13$

7.2.1 General Description $\ldots \ldots \ldots \ldots \ldots \ldots \ldots \ldots \ldots \ldots \ldots \ldots \ldots \ldots \ldots \ldots .13$

7.2 .2 Mr. Aleksandr V. Ivanov $\ldots \ldots \ldots \ldots \ldots \ldots \ldots \ldots \ldots \ldots \ldots \ldots \ldots \ldots \ldots \ldots .14$

7.2.3 Dr. Vitali T. Gotovchikov $\ldots \ldots \ldots \ldots \ldots \ldots \ldots \ldots \ldots \ldots \ldots \ldots \ldots \ldots \ldots .14$

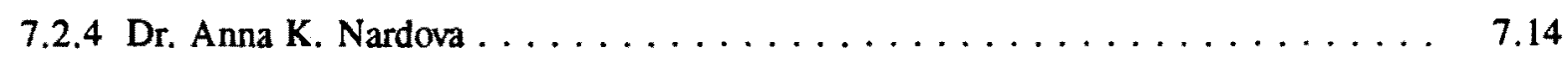

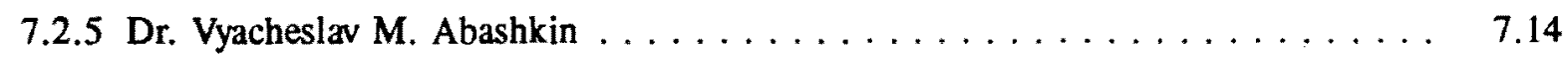

7.2 .6 Assessment $\ldots \ldots \ldots \ldots \ldots \ldots \ldots \ldots \ldots \ldots \ldots \ldots \ldots \ldots \ldots \ldots \ldots \ldots \ldots \ldots .21$

7.2.7 Possible Collaborations $\ldots \ldots \ldots \ldots \ldots \ldots \ldots \ldots \ldots \ldots \ldots \ldots \ldots \ldots \ldots \ldots .21$

7.3 Institute of Organoelement Compounds $\ldots \ldots \ldots \ldots \ldots \ldots \ldots \ldots \ldots .22$

7.3.1. Dr. Yurii A. Borisov $\ldots \ldots \ldots \ldots \ldots \ldots \ldots \ldots \ldots \ldots \ldots \ldots \ldots \ldots \ldots \ldots \ldots \ldots .22$

7.3.2 Dr. Yurii S. Nekrasov $\ldots \ldots \ldots \ldots \ldots \ldots \ldots \ldots \ldots \ldots \ldots \ldots \ldots \ldots \ldots \ldots .22$

7.3.3 Assessment $\ldots \ldots \ldots \ldots \ldots \ldots \ldots \ldots \ldots \ldots \ldots \ldots \ldots \ldots \ldots \ldots \ldots \ldots \ldots \ldots .22$

7.3.4 Possible Collaborations $\ldots \ldots \ldots \ldots \ldots \ldots \ldots \ldots \ldots \ldots \ldots \ldots .7 .22$

7.4 Institute of Organic Chemistry $\ldots \ldots \ldots \ldots \ldots \ldots \ldots \ldots \ldots \ldots \ldots \ldots \ldots \ldots .23$

7.4.1 Dr. Eugene S. Mortikov $\ldots \ldots \ldots \ldots \ldots \ldots \ldots \ldots \ldots \ldots \ldots \ldots \ldots \ldots \ldots .23$

7.4 .2 Assessment $\ldots \ldots \ldots \ldots \ldots \ldots \ldots \ldots \ldots \ldots \ldots \ldots \ldots \ldots \ldots \ldots \ldots \ldots \ldots .23$

7.4.3 Possible Collaborations $\ldots \ldots \ldots \ldots \ldots \ldots \ldots \ldots \ldots \ldots \ldots \ldots \ldots \ldots \ldots \ldots .23$

7.5 Ministry of Foreign Affairs $\ldots \ldots \ldots \ldots \ldots \ldots \ldots \ldots \ldots \ldots \ldots \ldots \ldots \ldots \ldots \ldots .23$

7.5.1 Directorate of International Scientific and Technological Cooperation $\ldots \ldots \ldots \quad 7.23$

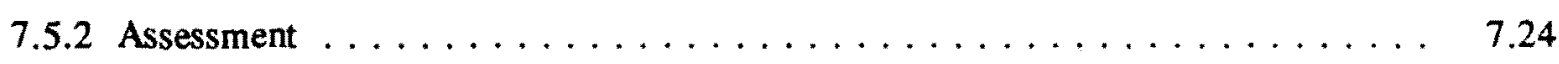

7.5 .3 Possible Collaborations $\ldots \ldots \ldots \ldots \ldots \ldots \ldots \ldots \ldots \ldots \ldots \ldots \ldots \ldots \ldots .24$ 
Appendix A - People Contacted $\ldots \ldots \ldots \ldots \ldots \ldots \ldots \ldots \ldots \ldots \ldots \ldots \ldots$

Appendix B - Materials Received $\ldots \ldots \ldots \ldots \ldots \ldots \ldots \ldots \ldots \ldots \ldots \ldots$ 


\section{Figures}

2.1 Dr. Sergei Khairulin at the Pilot Plant for Converting Hydrogen Sulfide to Elemental Sulfur at Novoil Refinery, Ufa, Russia $\ldots \ldots \ldots \ldots \ldots \ldots \ldots \ldots$

2.2 Dr. Mikhail Kerzhentsev in His Laboratory at the Institute of Catalysis, Novosibirsk, Russia

2.3 Dr. Valentin Titov and His Equipment for Measuring Thermodynamic Parameters of Volatile Inorganic Compounds at the Institute of Inorganic Chemistry, Novosibirsk, Russia

2.4 Apparatus for Growing Crystals at the Institute of Inorganic Chemistry, Novosibirsk,

2.5 Crystal Specimens Grown at the Institute of Inorganic Chemistry, Novosibirsk, Russia . .

2.6 Dr. Vladislav Torgov and His Extraction Cascade Used to Investigate Solvent Extraction at the Institute of Inorganic Chemistry, Novosibirsk, Russia $\ldots \ldots \ldots \ldots \ldots \ldots$

2.7 Synthetic Gems Produced at the Institute of Geology and Geophysics, Novosibirsk, Russia, Top Display Case . . . . . . . . . . . . . . . . . .

2.8 Synthetic Gems Produced at the Institute of Geology and Geophysics, Novosibirsk, Russia, Bottom Display Case . . . . . . . . . . . . . . . .

2.9 Apparatus for Measuring Density Changes at High Temperature Using Absorption of ${ }^{137}$ Cs Gamma Rays at the Institute of Thermal Physics, Novosibirsk, Russia . . . . . . . .

2.10 Dr. Sergei Stankus with a Diagram of his Apparatus for Measuring Densities at the Institute of Thermal Physics, Novosibirsk, Russia $\ldots \ldots \ldots \ldots \ldots \ldots$

2.11 Library of Spectral Data at the Institute of Organic Chemistry, Novosibirsk, Russia . . .

2.12 Laser Microscanner Used to Detect Bacterial Contamination of Water at the HighVoltage Biophysics Laboratory, Siberian Research Power Institute, Novosibirsk, Russia

2.13 Dr. Igor Ovchinnikov and the Laboratory-Scale Bioreactor for Water Sterilization at the High-Voltage Biophysics Laboratory, Siberian Research Power Institute, Novosibirsk, Russia

3.1 Ion-Exchange Column and Cartridge Fabricated at the Department of Analytical Chemistry and Technology, Bashkir State University, Ufa, Russia .

4.1 Computer Laboratory at Kemerovo State University

6.1 One-Person Chemistry Laboratory in the New Building at St. Petersburg State University 
6.2 Multiperson Chemistry Laboratory in the New Building at St. Petersburg State University

6.3 High-Resolution Mass Spectrometer in the New Building at St. Petersburg State University .............................

6.4 Dr. Yurii Batryakov and his High-Resolution XPS Spectrometer at the Radiochemistry Department, St. Petersburg State University $\ldots \ldots \ldots \ldots \ldots \ldots \ldots$

6.5 Ion-Selective Electrodes Produced by Dr. Yurii Ermolenko in the Laboratory of IonSelective Electrodes, Radiochemistry Department, St. Petersburg State University . . . . .

7.1 A Portion of the Waste Treatment Facility in the Basement of the Institute of Physical Chemistry, Moscow, Russia . . . . . . . . . . . . . . . .

7.2 Dr. Vladimir Gelis and Columns for Producing High-Purity Scandium at the Institute of Physical Chemistry, Moscow, Russia $\ldots \ldots \ldots \ldots \ldots \ldots$

7.3 Dr. Vyacheslav Kareta and Coworkers Demonstrating the Operation of Their System for Clarifying Solutions at the Institute of Physical Chemistry, Moscow, Russia

7.4 Linear Accelerator Used to Irradiate and Sterilize Medical Equipment at the Institute of Physical Chemistry, Moscow, Russia . . . . . . . . . . . . . . . .

7.5 Display Diagram of the Plasma Process for Converting Liquid Wastes to Fine Powder at the Institute of Chemical Technology, Moscow, Russia

7.6 Scale Model of Apparatus for Producing Microspheres of Metal Oxides at the Institute of Chemical Technology, Moscow, Russia

7.7 Scale Model of Apparatus for Solidifying Radioactive Wastes at the Institute of Chemical Technology, Moscow, Russia 


\subsection{Introduction}

In June 1993, a proposal was presented to the International Environmental Institute (IEI) in Kennewick, Washington, to establish cooperation and coordination to further pursue the interests of the United States of America and the Republic of Russia in the application and promotion of environmental technology; characterization, treatment, handling, isolation, and disposal of hazardous and radioactive materials; conversion of defense sites to other purposes; and technology transfer, cooperative programs, joint technology development and contractual research.

In response to this proposal, IEI and Pacific Northwest Laboratory (PNL) ${ }^{(a)}$ jointly provided funding to send Dr. Dennis W. Wester on a fact-finding mission to Novosibirsk, Moscow, and St. Petersburg, Russia. The trip covered a period of eight weeks, six of which were spent in Novosibirsk and adjoining or related cities and one of which was spent in each of Moscow and St. Petersburg. The general objectives of the trip were to establish a basis for cooperation between IEI and the Russian Academy of Sciences (RAS) for future coordination of mutual interests and objectives such as technology acquisition, development, demonstration, application, and commercialization; use of capabilities and assets developed by the U.S. Department of Energy (DOE) and the RAS; and expediting of cooperative agreements, personnel exchanges, joint ventures and other contractual relationships. The particular objectives of this trip were to evaluate the capabilities of the RAS to satisfy the technology needs associated with the cleanup of the Hanford Site and similar sites in the U.S. and to evaluate the expediency of establishing an IEI presence in Russia.

This report describes the laboratories and institutes I visited and the people I met.

(a) Pacific Northwest Laboratory is operated by Battelle Memorial Institute for the U.S. Department of Energy under contract DE-AC06-76RLO 1830. 


\subsection{Novosibirsk}

\subsection{Institute of Catalysis}

\subsubsection{General Description}

The visit to Novosibirsk was hosted by Professor Zinfer R. Ismagilov of the Institute of Catalysis (IC) and was coordinated by Dr. Sergei R. Khairulin of Professor Ismagilov's group. The IC in general and the Laboratory of Environmental Catalysis in particular served as the base from which other institutes and cities were visited. (I was provided with an office in a laboratory in the IC.) Dr. Khairulin accompanied me and introduced me to the institutes and scientists with whom I met on this part of the trip. There were frequent meetings with Professor Ismagilov, and he also accompanied us to other meetings.

The situation in the Laboratory of Environmental Catalysis of the IC is very critical since only about 40 to $50 \%$ of the budget is supplied by the government. The remainder must be obtained from contracts with others, especially Western concerns. The state of the laboratory is similar to American university laboratories. There are very good machine and glass-blowing shops, an electrical repair shop, and pilot-plant facilities, which I did not see because the door was locked. Also, the compressed air system in the building was down, so there was little activity on the pilot plants and in the glass shop.

The examination of research in the IC was limited to Professor Ismagilov's group. There were other groups of interest in the IC, for example, a group working on zeolites, but arrangements to visit with these scientists did not materialize even though I had suggested that this could be very interesting.

\subsubsection{Dr. Sergei R. Khairulin}

Dr. Khairulin is working on several projects involving the catalytic decomposition of hydrogen sulfide. The most impressive of these has reached the pilot-plant stage. Figure 2.1 shows the pilot plant that has been constructed at the Novoil refinery in Ufa, an industrial city in the European part of Russia. This plant treats natural gas that is high in hydrogen sulfide by reducing it to elemental sulfur. The elemental sulfur was visible as a yellow mass leaking from pipe joints. In addition to this project, Dr. Khairulin is working on others, including one to remove hydrogen sulfide from geothermal steam in Kamchatka.

\subsubsection{Dr. Mikhail A. Kerzhentsev}

The main goal of Dr. Kerzhentsev's work is to develop the catalytic heat generators; he is working to commercialize these generators. A typical photograph of Dr. Kerzhentsev is shown in Figure 2.2, which will appear later in the assessment of the IC. 


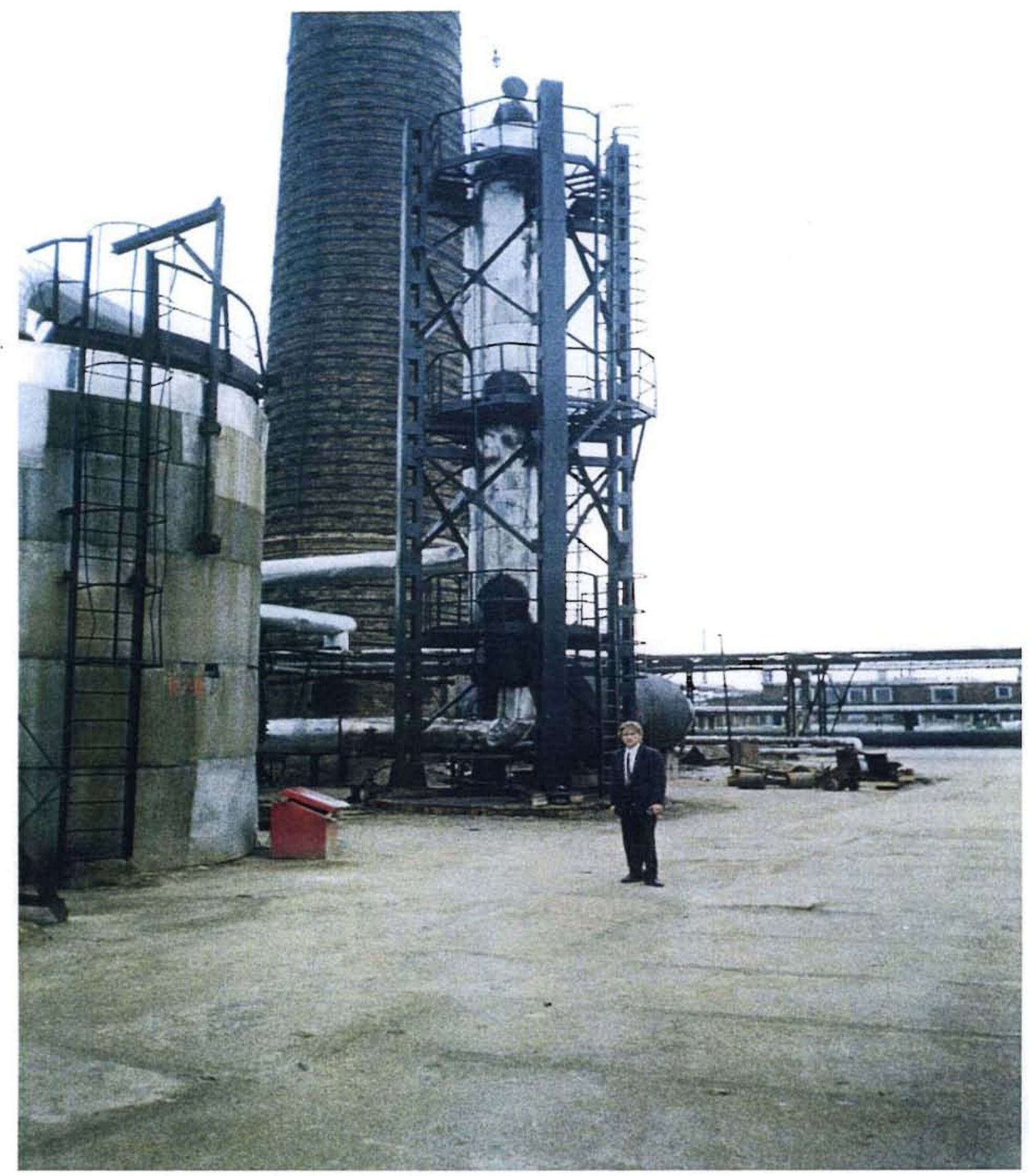

Figure 2.1. Dr. Sergei Khairulin at the Pilot Plant for Converting Hydrogen Sulfide to Elemental Sulfur at Novoil Refinery, Ufa, Russia 



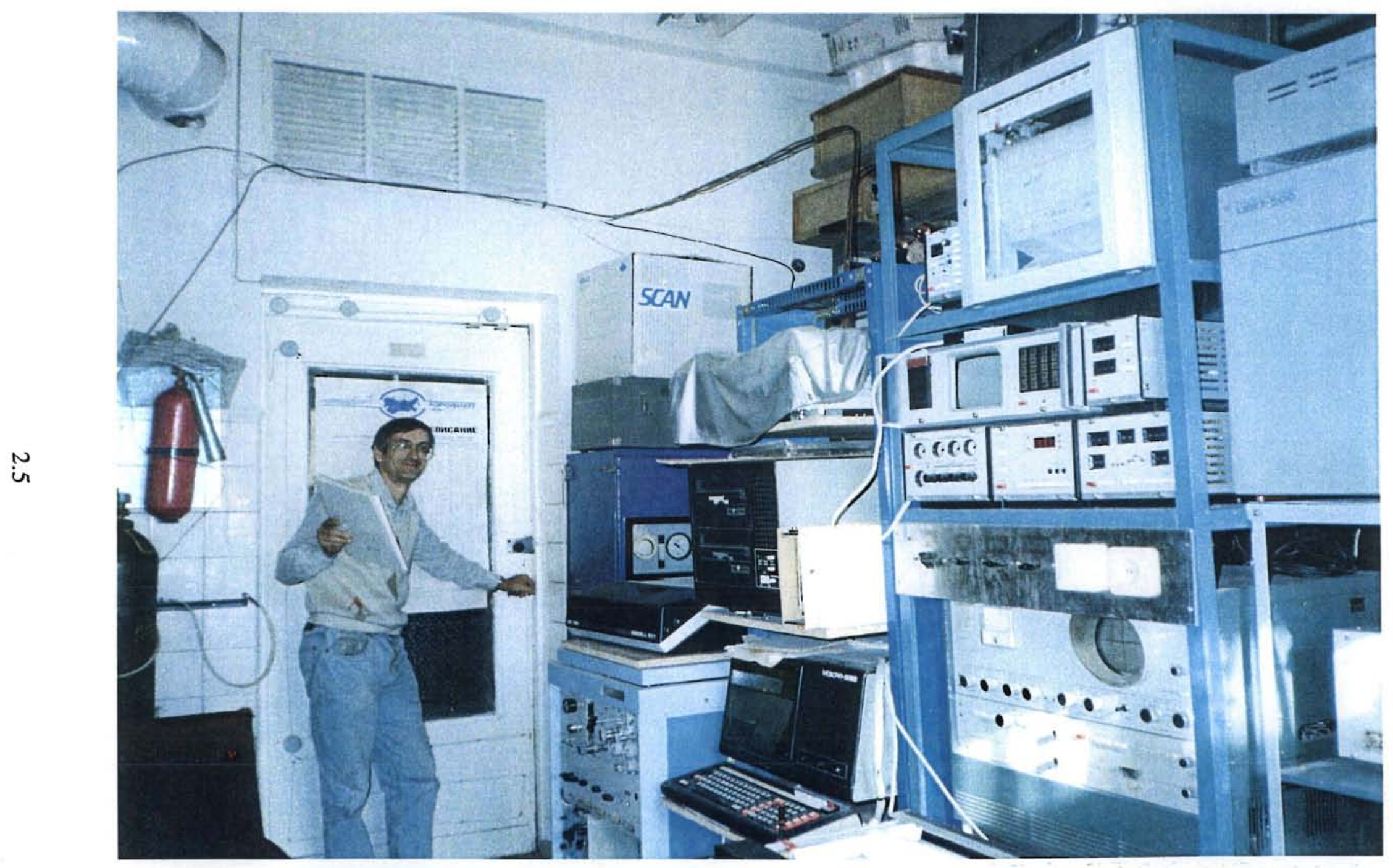

Figure 2.2. Dr. Mikhail Kerzhentsev in His Laboratory at the Institute of Catalysis, Novosibirsk, Russia 



\subsubsection{Dr. Dmitrii A. Arendarskii}

The work of Dr. Arendarskii involves physical characterization methods of catalysts. These are mainly infrared (IR) and thermal desorption methods. He also mentioned electronic paramagnetic resonance (EPR), elemental analysis, and other methods. He discussed his thesis and explained how various additives to the catalyst support can stabilize the catalyst. He demonstrated a catalytic heat generator that looked very dangerous since flames shot out of it several times as it was starting. Dr. Arendarskii gave me the specifications and instructions for the generator.

\subsubsection{Dr. Natal'ya A. Koryabkina}

Dr. Koryabkina is involved with fabricating catalyst supports out of alumina. She gave me an advertisement for their spherical alumina.

\subsubsection{Dr. Andrei V. Simakov and Dr. Aleksandr A. Kirchanov}

These scientists are working on $\mathrm{V} / \mathrm{TiO}_{2}$ catalysts for $\mathrm{NO} / \mathrm{NO}_{2}$ destruction. They suggested that they need extended $x$-ray absorption fine structure (EXAFS) data to determine why the catalyst loses activity as it is heated. They were also interested in solving the problem of $\mathrm{NO}_{\mathrm{x}}$ destruction involved with the vitrification plant. They asked for data such as the concentration, and flow rate, etc.

\subsubsection{Dr. Vladimir B. Fenelonov}

Dr. Fenelonov has worked with the structure of porous materials. In particular, he has studied in great detail the migration of salts as solutions in the pores evaporate. This work should be applicable to grout since the principles are the same. In fact, Dr. Fenelonov has studied concrete in connection with the resistance of bridge supports to weathering during the very cold Siberian winters.

\subsubsection{Director Kirill I. Zamaraev}

Director Zamaraev is a very impressive individual. Besides being the director of the IC, he was recently elected to be the next president of the International Union of Pure and Applied Chemistry (IUPAC). He, of course, has a very busy schedule but was able to find the time to meet with Professor Ismagilov, Dr. Khairulin, and myself. The subject of our meeting was the Memorandum of Understanding that had been given to Professor Ismagilov during his visit to the Hanford Site in May and June. Director Zamaraev had examined the Memorandum of Understanding and found that it was written as an agreement between the IEI and the Siberian Division of the RAS. With the stipulation that the agreement be reworded to reflect the fact that it would be between the IC and the IEI, he readily signed the agreement.

\subsubsection{Assessment}

The main goal of the Laboratory of Environmental Catalysis in the IC seems to be to support the petrochemical industry. Thus, the major projects of the laboratory involve purifying natural gas, manufacturing catalytic heat generators, destroying nitrogen oxides, and fabricating catalyst supports. Recently, the laboratory has become interested in the problems at the Hanford Site, mainly due to two visits by Professor Ismagilov to the site. In my judgement, the technology being developed in the 
Laboratory of Environmental Catalysis may be applied to Hanford problems. This is particularly relevant with respect to the catalytic destruction of nitrogen oxides since DOE has agreed through the Tri-Party Agreement to build two vitrification plants at Hanford. The earlier suggestions of Professor Ismagilov that grout research could be carried out at the IC now seem irrelevant since grout has been dropped as a possible waste form at Hanford. In addition, there may be uses for the extensive knowledge about alumina that has been gathered in the laboratory.

The physical condition of the laboratories in the IC is poor. The equipment is aged by Western standards. This is evident in Figure 2.2, which shows equipment typical of that in most of the laboratories. One can see a strip-chart recorder, an oscilloscope, and a computer. However, the scientists seem very capable of using their equipment to gather and analyze data, and to draw conclusions about the meaning of the data. Keep in mind that any financial support directed toward this institute will very likely be used to purchase new equipment, improve the building, and support the scientists. After a certain period of rebuilding, meaningful research results may begin issuing from the IC.

\subsubsection{Possible Collaborations}

\section{Catalytic Destruction of Nitrogen Oxides}

Russians: $\quad$ Dr. Andrei V. Simakov and Dr. Aleksandr A. Kirchanov

Americans: Westinghouse Hanford Company vitrification plants

\section{Catalysis of Hydrogen Sulfide Conversion to Sulfur}

Russians: Dr. Sergei R. Khairulin

Americans: Engineering Technology Center at PNL

Materials and Chemical Sciences Center at PNL

(Materials Sciences Department, Lambert Bates)

Other PNL Staff

\section{Catalytic Generators of Heat}

Russians: Dr. Mikhail A. Kerzhentsev

Americans: Materials and Chemical Sciences Center at PNL Other PNL Staff

\section{Analytical Methods for Analyzing Catalyst Supports}

Russians: Dr. Dmitrii A. Arendarskii

Americans: Materials and Chemical Sciences Center at PNL

(Analytical Chemistry Department, Materials Sciences Department, Lambert Bates)

Other PNL Staff

\section{Production of Alumina and Other Catalyst Supports}

\section{Russians: Dr. Natal'ya A. Koryabkina}

Americans: Molecular Sciences Research Center at PNL Materials and Chemical Sciences Center at PNL (Materials Sciences Department, Lambert Bates) Other PNL Staff 


\subsection{Institute of Inorganic Chemistry}

\subsubsection{General Description}

Yurii G. Stenin, Assistant Director of the Institute of Inorganic Chemistry (IIC), presented me with a brochure outlining the institute's major areas of research. Among the most interesting are optical study methods, radiation chemistry, the chemistry of extraction processes, sorption and ion-exchange processes, and the ecology of aqueous systems. In addition, there are projects on metallocarboranes, mixed oxide phases, separation and purification of inorganic compounds, development of new technology and diagnostic equipment, creation of databases of thermodynamic properties, and development of information systems and modeling. At a later date, Academician Fyodor A. Kuznetsov explained the material in the IIC brochure in more detail. The IIC is mainly interested in the structures of the mixed metal oxides. The extraction and re-extraction and sorption studies have been directed toward the precious metals industry. The ecological studies have focused on ion-selective electrodes to monitor aqueous systems. They have built apparatus for growing large single crystals of several tungstates.

On another front, an International Centre for Materials Research, Siberia (ICMR-S) has been established. The ICMR-S is open to participants from other countries, as well as to institutes, groups, and individual specialists. The following institutes have joined the ICMR-S: Institute of Inorganic Chemistry, Novosibirsk; Institute of Semiconductor Physics, Novosibirsk; Institute of Solid State Chemistry, Novosibirsk; Institute of Physics, Krasnoyarsk; Institute of Organic Chemistry, Irkutsk. Specialists from these institutes are working in areas including the chemistry and theory of solid-state physics; material design; synthesis of starting materials and functional materials for semiconductors, optical materials, ferroelectrics, and superconductors; development of new material technologies (crystal, films, multilayer structures, ceramics, coatings); methods for material characterization (composition, structure, optical, electrical, etc.); development of new science instruments and technical equipment; creating material databases and banks; and development of methods for modeling materials and processes.

The main objective of the ICMR-S is to assist its members in establishing and maintaining contacts with specialists in materials science and technology from academic, industrial, and educational institutes from different countries. Special accent is made on cooperation in the Asia-Pacific region. The ICMR-S achieves its objectives by 1) preparing and disseminating information on material-oriented activity in the Asia-Pacific region on materials science and technology, 2) organizing short- and longterm visits of foreign students and specialists to institutes and laboratories of the Siberian Division of the RAS and to university laboratories and industrial R\&D laboratories in different Siberian cities, and 3) organizing specialist exchanges. A number of Russian industrial organizations as well as institutions from other countries are considering the possibility of joining ICMR-S as members and sponsors. More details can be obtained and questions answered by writing to:

Academician F. A. Kuznetsov, Director or Dr. D. M. Tolstyakov, Executive Director, ICMR-S Institute of Inorganic Chemistry Siberian Branch of the Russian Academy of Sciences 630090, Novosibirsk-90, Russia Lavrentiev Ave., 3 


\subsubsection{Dr. Vladimir V. Volkov}

Dr. Volkov is head of a laboratory interested in synthesizing hydride compounds. One of their focus areas is metal dicarbollides. Among other species, they have synthesized a number of polymeric cobalt dicarbollides that show enhanced solubility in organic solvents, e.g., acetone.

\subsubsection{Dr. Vladimir L. Bogatyrev}

Dr. Bogatyrev heads a laboratory working on mechanisms of ion exchange. The laboratory has focused on three areas of interest. The first involves coating ion-exchangers with alkylanilinium salts through the reaction $R H+A A \rightarrow R(H A A)$, where $R H$ is the ion exchanger and AA is the alkylaniline. These exchangers show selectivity for metals that form insoluble alkylanilinium salts. The second area involves equilibrium between cation exchangers. For example, a cation exchanger in the Na- and $\mathrm{H}$-forms will undergo equilibration if placed together in a medium. In addition, if different cation exchangers are prepared in different forms, e.g., one as the $\mathrm{H}$-form and the other as the Cs-form, they also will equilibrate but with different amounts of each ion. Finally, tetraalkylammonium (TAA) ions adsorbed to ion exchangers exhibit properties similar to those of clathrates owing to the hydration sphere around the TAA. As the temperature is lowered, different ions show different tendencies to form such clathrates. Thus, the coated ion exchangers show selectivity for different ions as critical temperatures are reached.

\subsubsection{Dr. Igor' $\mathrm{K}$. Igumenov}

Dr. Igumenov heads a laboratory that is studying halide compounds. The laboratory is interested in volatile compounds of the platinum metals. They have developed methods of coating ceramics and other materials with platinum metals to reduce the costs of preparing the electrodes and crucibles used to grow large crystals. They have also been active in coating materials with metal oxides, mainly for electronic applications such as superconductors. However, they mentioned that they have worked with such ion-exchangers as $\mathrm{Ti}$ and $\mathrm{Zr}$ oxides.

\subsubsection{Dr. Lev N. Mazalov}

Dr. Mazalov has developed a stand-alone instrument for measuring $x$-ray photoelectron spectroscopy (XPS) spectra of light atoms such as carbon, nitrogen, and oxygen, and EXAFS. This is the only instrument of its kind in the world, according to the inventor. Using this instrument, Dr. Mazalov can determine both the degree of binding between two atoms and the orbitals involved in the bonding. The laboratory has used the instrument to look at simple molecules and several metal complexes, including some complexes of phosphine oxides and related molecules.

\subsubsection{Dr. Valentin A. Titov}

Dr. Titov works on thermodynamic calculations of molecules. He has worked on such systems as $\mathrm{Sn}, \mathrm{I}, \mathrm{SnI}_{4}$; $\mathrm{Al}, \mathrm{Si}, \mathrm{O}$; and metal oxides. He has several laboratories in IIC where he measures thermodynamic parameters. Dr. Titov and some of his equipment are shown in Figure 2.3. He has also developed a program that calculates thermodynamic parameters for compounds as functions of temperature. For example, the program can calculate $\Delta \mathrm{H}, \Delta \mathrm{G}$, and $\Delta \mathrm{S}$ for salts such as $\mathrm{NaCl}, \mathrm{KBr}$, and others from temperatures ranging from 300 to $1200 \mathrm{~K}$. 


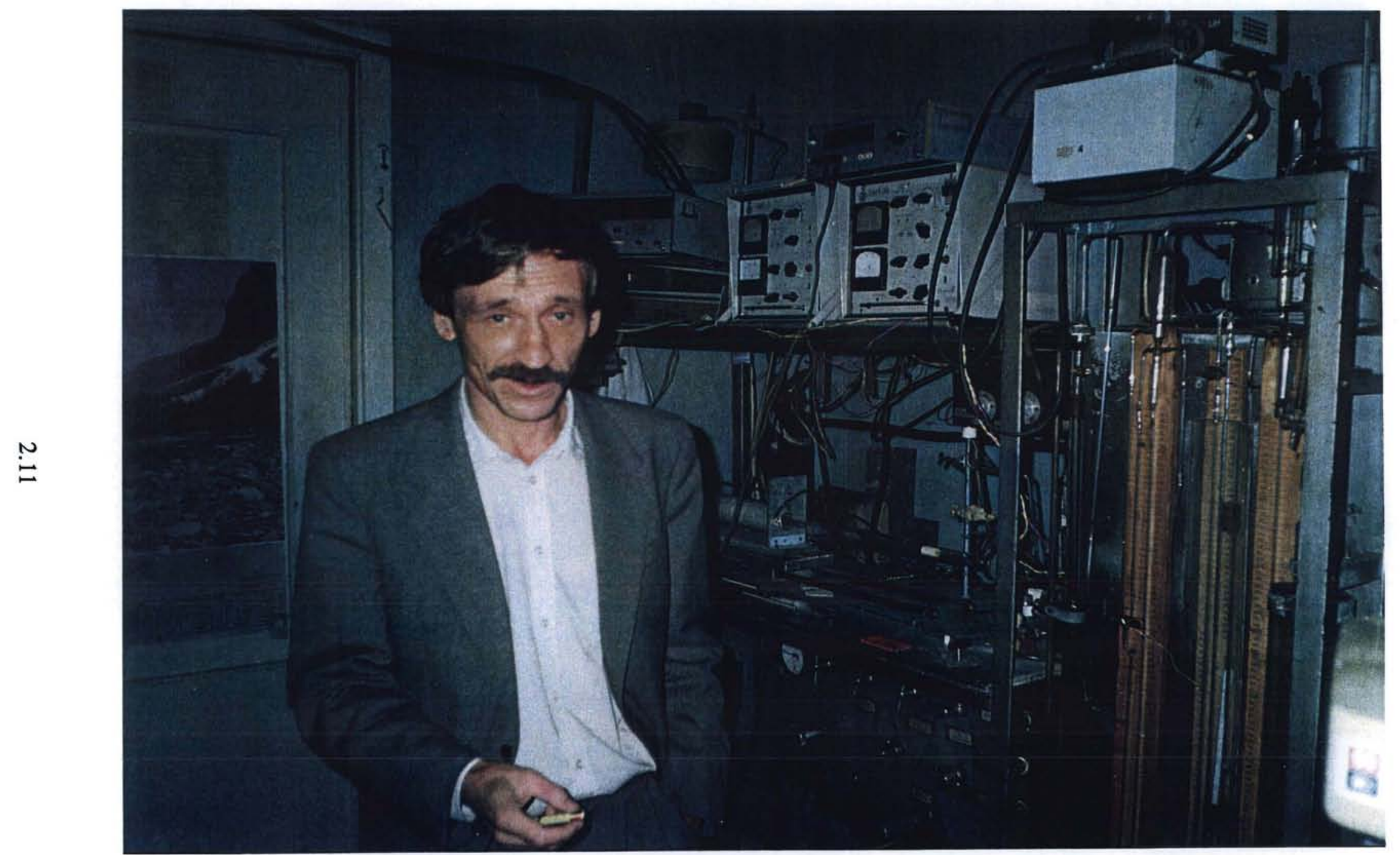

Figure 2.3. Dr. Valentin Titov and His Equipment for Measuring Thermodynamic Parameters of Volatile Inorganic Compounds at the Institute of Inorganic Chemistry, Novosibirsk, Russia 



\subsubsection{Dr, Yan V. Vasil'ev and Dr. Anatolii A. Pavlyuk}

Dr. Vasil'ev is in charge of the crystal growing laboratory. He has several apparatus for growing crystals at low temperatures $\left(\sim 700^{\circ} \mathrm{C}\right)$ by a method developed at IIC. Several of these apparatuses are shown in Figure 2.4. The method enables extremely perfect crystals to be grown of compounds that previously could only be grown as crystals with numerous imperfections. Dr. Pavlyuk also works in the crystal growing laboratory. They have had great success growing crystals of alkali-trivalent tungstates and molybdates from fluxes of alkali tungstates. Typical examples of the crystals that they can grow are shown in Figure 2.5. He is very enthusiastic about his work. However, funding has been cut off for most of the projects the laboratory is working on. Dr. Pavlyuk would very much like to work together with a Western company to market his laboratory's crystals.

\subsubsection{Dr. Vladislav G. Torgov}

Dr. Torgov is the Head of the Laboratory in IIC. He has studied extraction mechanisms for many years. Dr. Torgov is shown with his extraction cascade in Figure 2.6. His research involves several areas. The first includes studying oxides of the formula $R_{n} X O$, where $X=N, P, S, S e, T e$, and As as extractants for $\mathrm{U}$, Th, and REE (hard metals). Several of the organic residues are cyclic compounds. The strongest of all is a trioctylamine oxide. One of his studies found that uranium is extracted as a polymer by certain ligands. The second area of Dr. Torgov's research involves compounds of the formula $R_{n} X$, where $X=N, P, S, T e, A s$, etc., as extractants for Pt, Au, Ag, and Hg (soft metals). The extractants are readily available in petroleum fractions. The sulfides have been used in a pilot-scale demonstration to extract Pd and Au. Dr. Torgov's third area of study involves $\pi$-donor solvents and their effect on extraction. The effect was discovered for extraction of $\mathrm{Sb}, \mathrm{As}(\mathrm{III}), \mathrm{Se}, \mathrm{Te}$, and their halides. The formation of $\pi$-donor complexes with several of these compounds was noted. Other $\pi$-donors that have been used are hexene for $\mathrm{Pd}, \mathrm{SeX}_{4}$, and $\mathrm{TeX}_{4}$. It was also very interesting that hexene extracts such compounds as $\mathrm{OsO}_{4}$ and $\mathrm{SeX}_{4}$ by forming adducts. Some of Dr. Torgov's new interests involve ion-exchange extraction and micellar extraction. He has also worked on extracting Pd and $\mathrm{Rh}$ from spent fuel and on the speciation of $\mathrm{Rh}$ in plutonium-uranium-extraction (PUREX) process solutions. He collaborates with VNIINM, a leading institute in Moscow that has been involved with the radiochemical industry.

\subsubsection{Assessment}

The IIC in Novosibirsk has been involved with research that has touched on problems related to those facing the Hanford Site. Several examples that can be cited are the work on cobalt dicarbollides, which was performed mainly out of scientific curiosity about the fundamental chemistry of these species, and the study of solvent extraction, which was performed to support the platinum metals industry. The scientists of IIC are very competent and exhibit a high degree of enthusiasm for their work.

Several of the laboratories in IIC have very modern equipment even by Western standards. The computer program that was developed to calculate thermodynamic properties was very impressive. The apparatus for growing crystals (Figure 2.4) are possibly the only ones of their type in the world and obviously produce crystals of higher quality than previously available (Figure 2.5). However, like the IC, several laboratories in IIC have instruments that are aged, of poor quality, in disrepair, or all of 



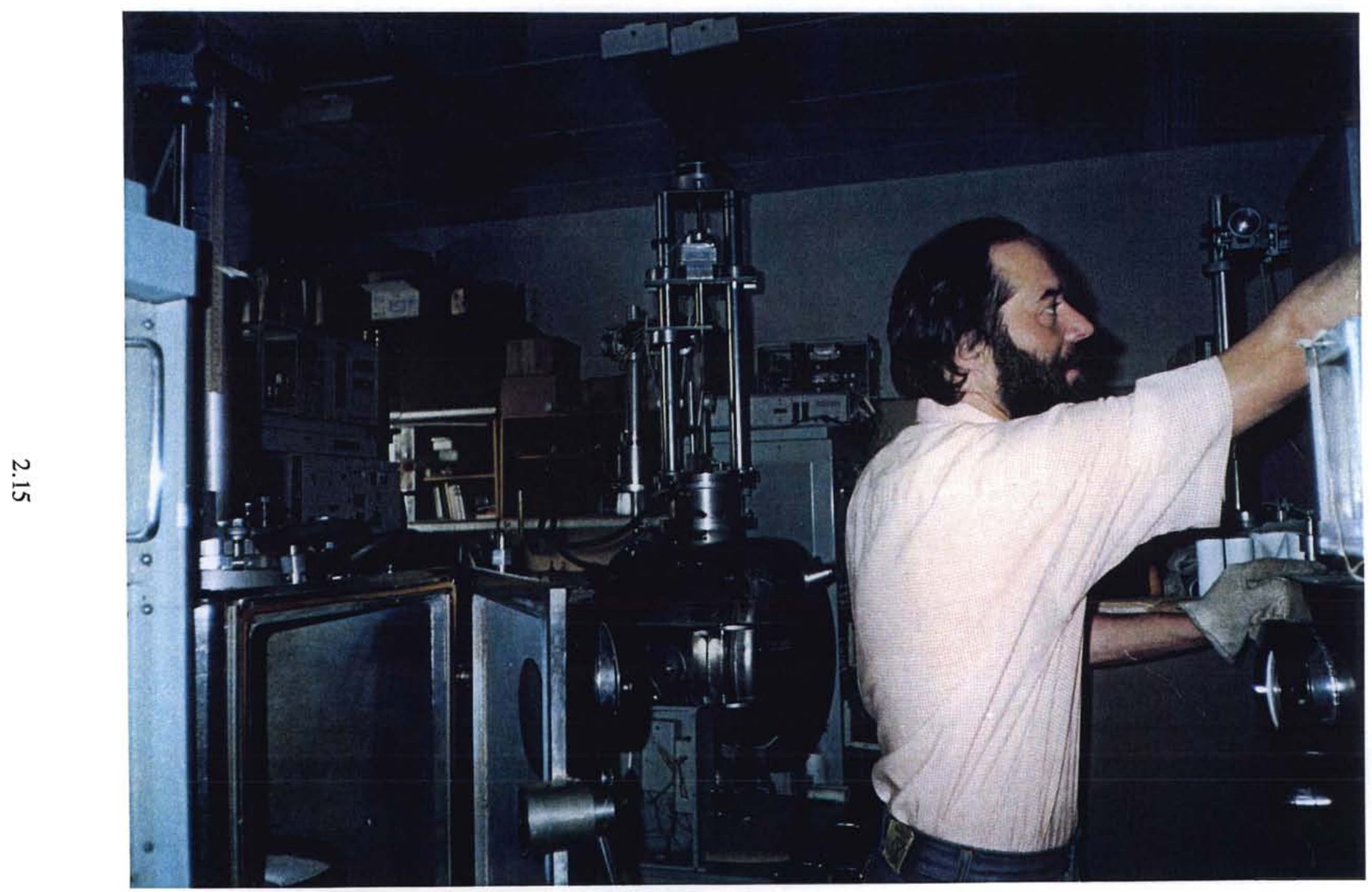

Figure 2.4. Apparatus for Growing Crystals at the Institute of Inorganic Chemistry, Novosibirsk, Russia 



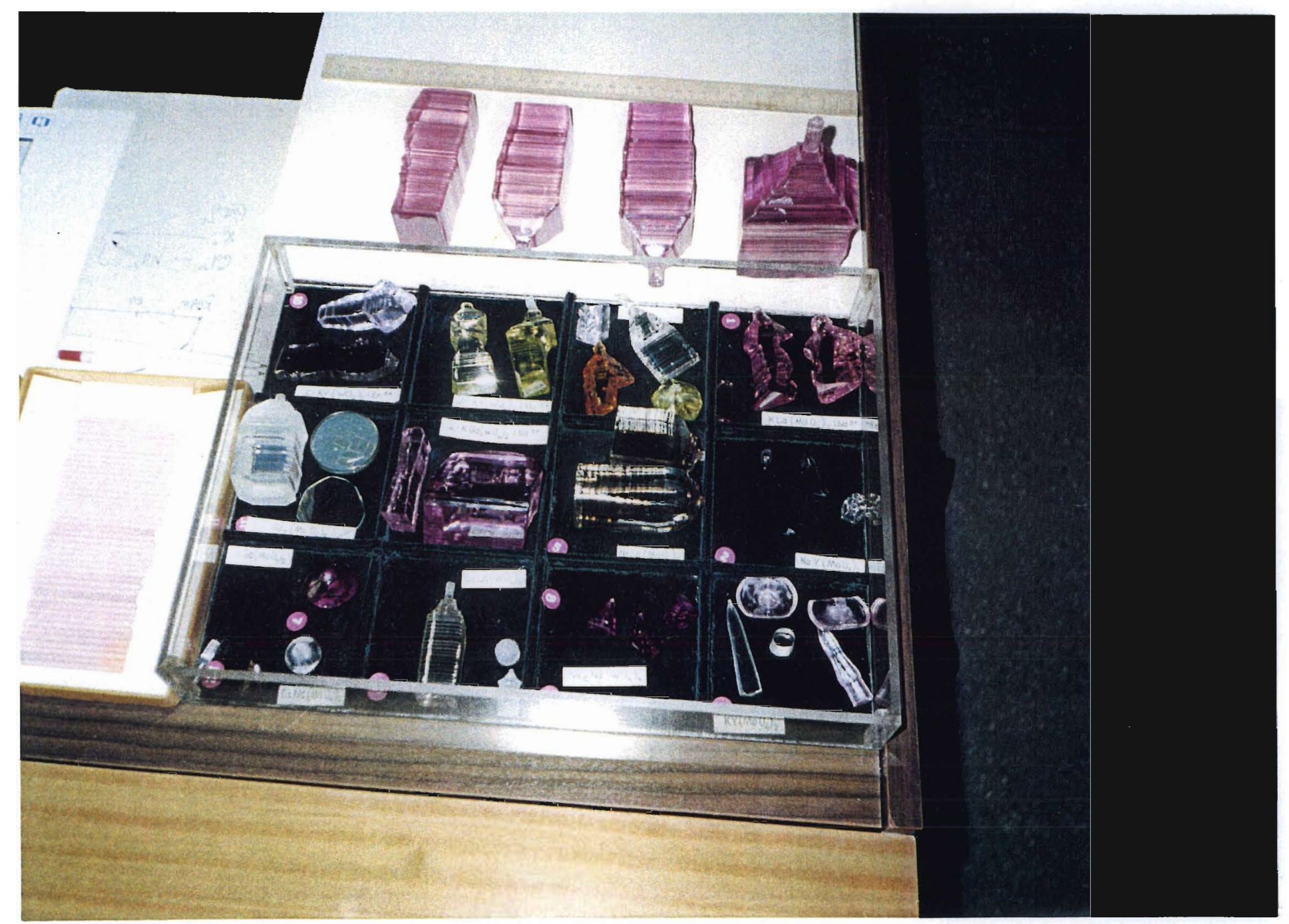

Figure 2.5. Crystal Specimens Grown at the Institute of Inorganic Chemistry, Novosibirsk, Russia 


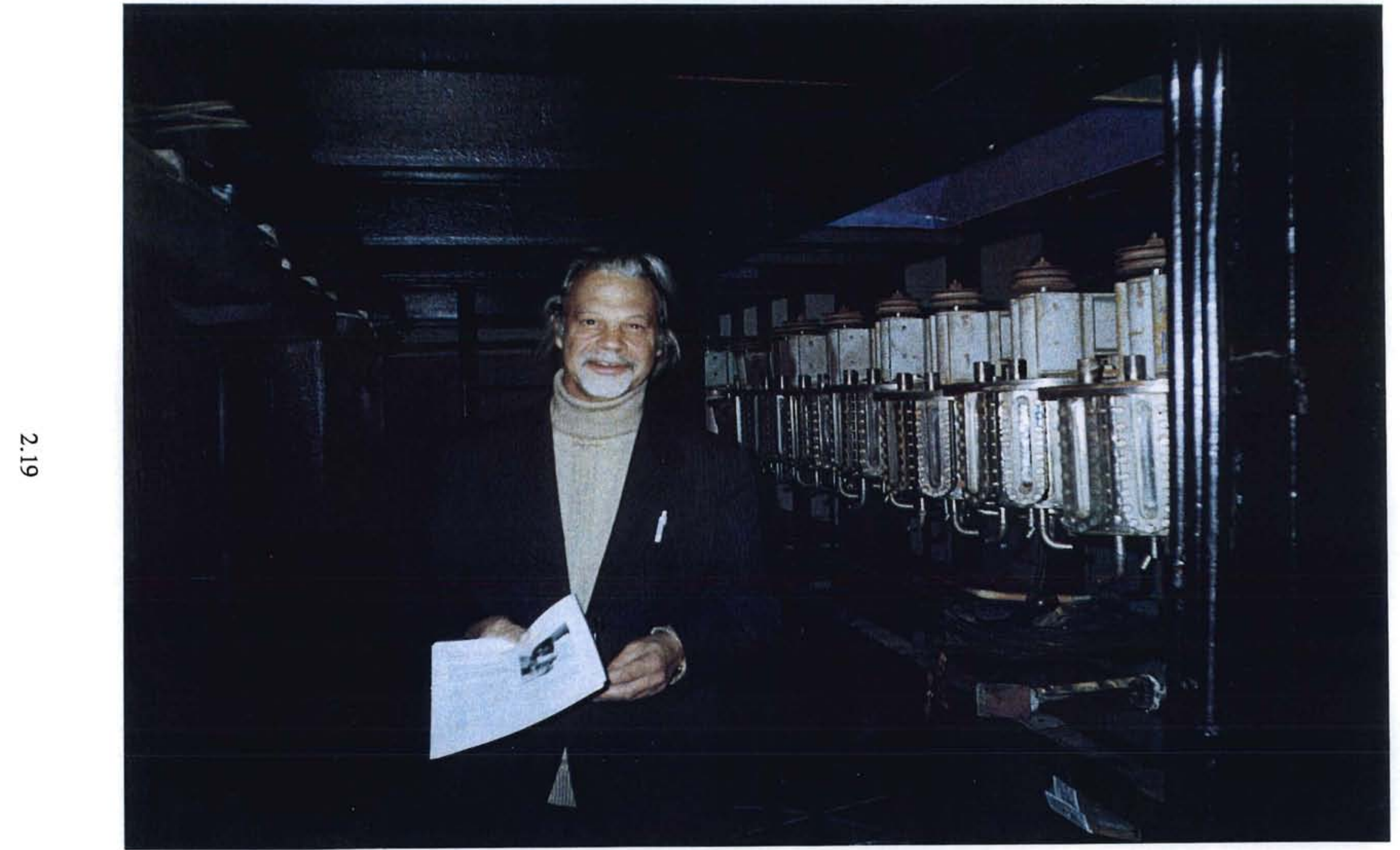

Figure 2.6. Dr. Vladislav Torgov and His Extraction Cascade Used to Investigate Solvent Extraction at the Institute of Inorganic Chemistry, Novosibirsk, Russia 
.

. 
the above. For example, the apparatus used by Dr. Titov to measure thermodynamic properties of volatile inorganic compounds can only be described as crude and primitive. Figure 2.3 shows a typical example in which pressures are measured by poorly fabricated manometers and outdated instruments. Also, note in Figure 2.6 that the extraction cascade Dr. Torgov used to study solvent extraction is obviously not in working condition since the vessels are not connected by tubing.

\title{
2.2.10 Possible Collaborations
}

\author{
International Centre for Materials Research \\ Russians: Dr. Fyodor A. Kuznetsov \\ Americans: Molecular Sciences Research Center at PNL
}

Dicarbollides, Tetrahydroborates, Metal Hydrides

Russians: Dr. Vladimir Vladimirovich Volkov

Americans: Materials and Chemical Sciences Center at PNL .

(Process Chemistry Section)

Other PNL Staff

Mechanism of Ion Exchange, Tetraalkylammonium Extractants, Clathrates as Extractants

Russians: Dr. Vladimir L. Bogatyrev

Americans: Materials and Chemical Sciences Center at PNL

(Process Chemistry Section)

Other PNL Staff

Volatile Compounds of Platinum Metals, Superconductors, Ti and Zr Oxides

Russians: Dr. Igor K. Igumenov

Americans: Molecular Sciences Research Center at PNL

(super conductors, melter electrodes, optical recording media)

Other PNL Staff

XPS, EXAFS of Light Atoms, Phosphine Oxides

Russians: Dr. Lev N. Mazalov

Americans: Molecular Sciences Research Center at PNL

( $\mathrm{x}$-ray photoelectron spectroscopy, $\mathrm{x}$-ray absorption

fine structure)

Other PNL Staff

Thermodynamic Calculations, Computer Program for These Calculations

Russians: Dr. Valentin A. Titov

Americans: Information Systems

Material and Chemical Sciences Center at PNL

Earth and Environmental Sciences Center at PNL

(Dhan Rai)

Other PNL Staff 
Growth of Alkali-trivalent Molybdates and Tungstates from Fluxes

Russians: $\quad$ Dr. Yan V. Vasil'ev and Dr. Anatoly A. Pavlyuk

Americans: Molecular Sciences Research Center at PNL

(laser crystals)

\subsection{Institute of Geology and Geophysics}

\subsubsection{General Description}

Academician Aleksei E. Kontorovich, Deputy Director of the Institute of Geology and Geophysics (IGG) explained in detail that the main directions of the IGG are connected with exploring and developing the Siberian petroleum reserves, the Siberian mineral resources (mainly platinum metals), and recently, producing synthetic minerals and gems. The Gem production has become so exacting that the crystallographers cannot tell the difference between the synthetic spinels produced by the institute and authentic natural samples. Typical examples of the gems that they are producing can be seen in Figures 2.7 and 2.8 .

Academician Kontorovich mentioned that IGG has no activity regarding ecological problems. Although the IGG is not concerned at this time with ecological problems, he knows that Academician Koptyug, the head of the Siberian Division of the RAS, is very interested in ecological questions. Academician Kontorovich said that IGG has a team of highly trained specialists that would be willing to work on ecological problems should the demand arise.

The IGG has about 1,200 staff, of which 200 are doctors. This is a very high ratio for the institutes in Novosibirsk. The IGG is better funded than most others in Novosibirsk by about 20 to $30 \%$. However, even with that level of funding, their financial situation is still very poor.

\subsubsection{Dr. Vitalii N. Domvskii}

Dr. Dorovskii works in close collaboration with the Institute of Mathematics. He has developed equations applicable to problems involving filtration and shock wave transmission through solid media. Dr. Dorovskii is a very enthusiastic individual and talks excitedly about his work. He completed an application for the Special American Business Internship Training (SABIT) program at PNL and submitted it before I left Novosibirsk.

\subsubsection{Dr. Fyodor V. Sukhorukov}

Dr. Sukhorukov is the head of the laboratory in which studies are performed on radionuclide migration in soil, primarily the vertical migration of fallout isotopes near the Semipalatinsk test region. Since he has only a gamma-spectrometer, he studies mainly ${ }^{137} \mathrm{Cs}$ migration. The counting equipment 


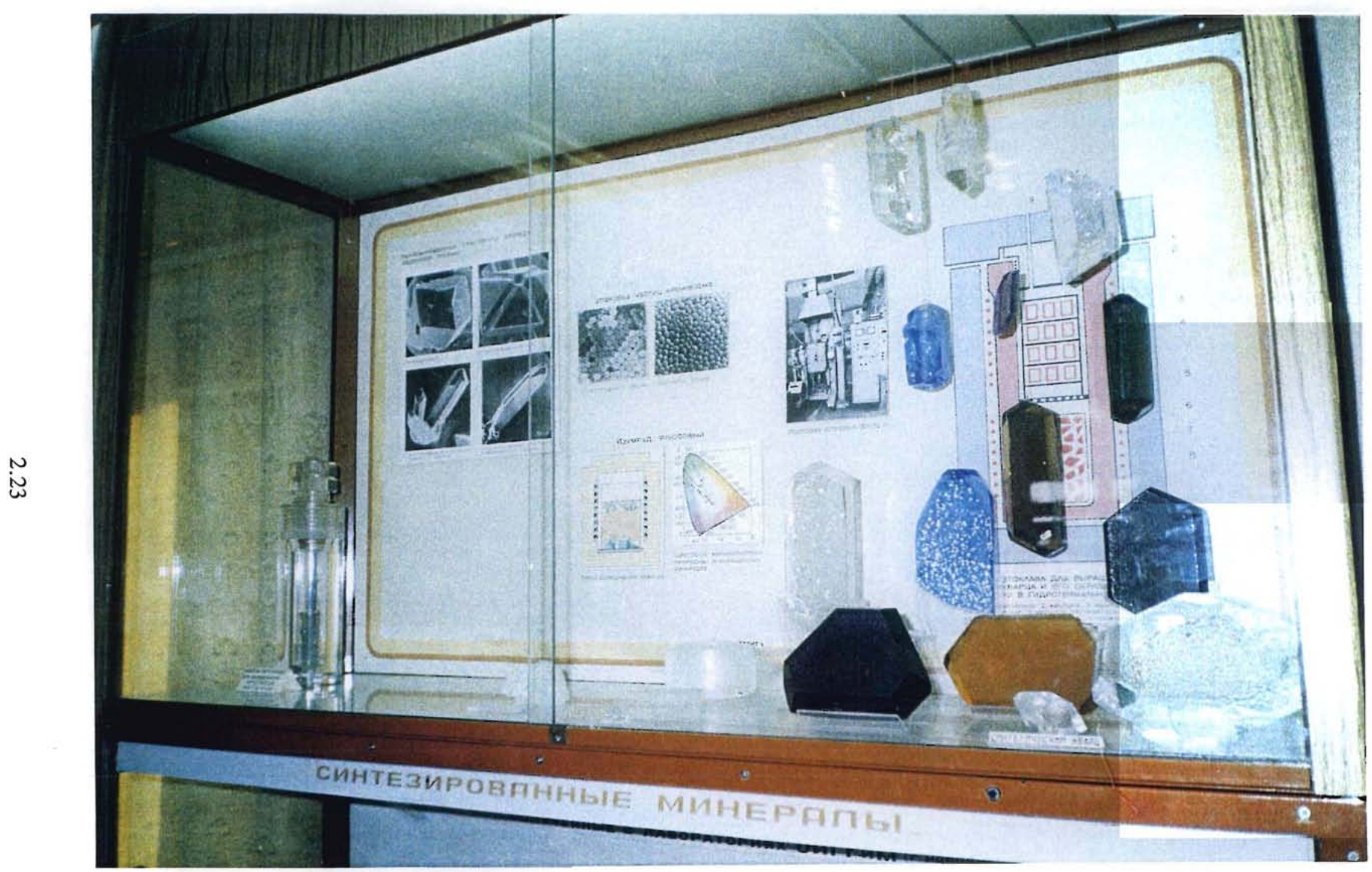

Figure 2.7. Synthetic Gems Produced at the Institute of Geology and Geophysics, Novosibirsk, Russia, Top Display Case 


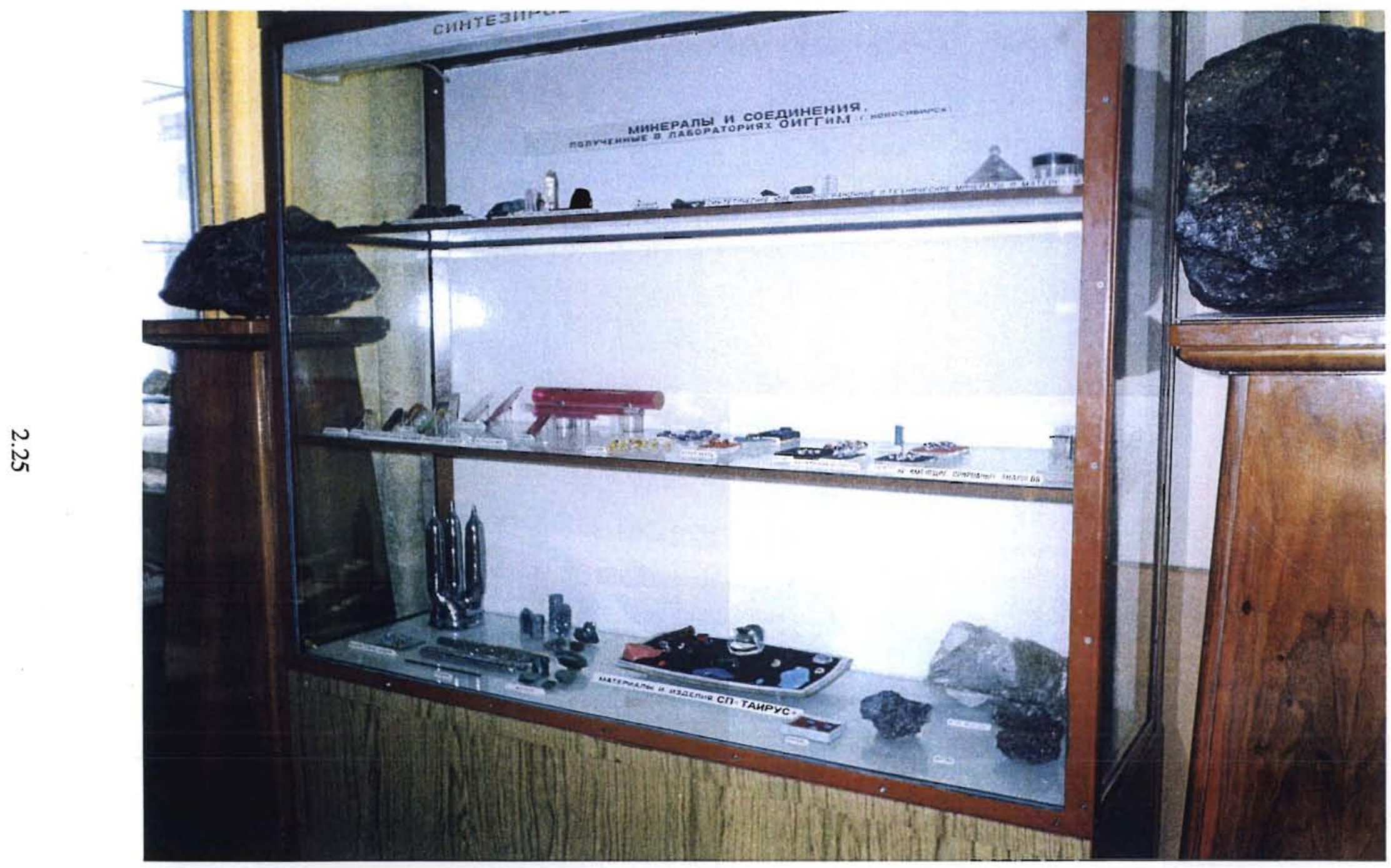

Figure 2.8. Synthetic Gems Produced at the Institute of Geology and Geophysics, Novosibirsk, Russia, Bottom Display Case 
in his laboratory is very sophisticated. A low-background shielded room provides a very suitable environment for measuring samples with very low activity. For example, the laboratory received $0.5 \mathrm{mg}$ of moon rocks and was able to determine several of the elements present after neutron activation.

\subsubsection{Assessment}

Owing to my cursory examination of this institute, the following assessment may contain some inaccuracies. The IGG has traditionally been involved with the exploration, mining, and development of the natural resources of Siberia. In the words of its deputy director, IGG is little concerned about ecological problems.

The work of Dr. Sukhorukov could be very interesting to scientists developing models of radionuclide migration on the Hanford Site. However, the equipment available to Dr. Sukhorukov is old by Western standards. This applies even to the low-background counting room, in which the instrumentation is reminiscent of the 1970 s. The work of Dr. Dorovskii might be interesting to the same Hanford scientists. The synthesis of artificial gems could possibly be of interest to PNL.

\subsubsection{Possible Collaborations}

Fundamental Theories for Describing Composite Hydrodynamic Structures, Two Velocity Hydrodynamics, Kinetics of Ore Formation, Filtration

Russians: Dr. Vitalii N. Dorovskii

Americans: Molecular Sciences Research Center at PNL

Applied Physics Center at PNL

Other PNL Staff

Migration of Radionuclides in Soil

Russians: Dr. Fedor V. Sukhorukov

Americans: Earth and Environmental Sciences Center at PNL

(Yasuo Onishi, Glendon Gee)

\subsection{Institute of Thermal Physics}

\subsubsection{General Description}

The Institute of Thermal Physics (ITP) studies heat- and mass-transfer theory, rarefied gas dynamics, electrodynamics and heat transfer in a thermal plasma flow, laser physics, and lowtemperature energetics.

\subsubsection{Dr. Sergei V. Stankus}

Dr. Stankus researches density changes of metals and their oxides in the range from room temperature up to $2,200 \mathrm{~K}$. He uses a ${ }^{137} \mathrm{Cs}$ source to irradiate the samples and monitors the absorption as a 
function of temperature. The apparatus used by him is shown in Figure 2.9 and is diagrammed in Figure 2.10. By noting the change of absorption, he can calculate the density. He also informed me about the All-Union Association "IZOTOP." This association, located in Moscow, produces sources for production of alpha-, beta-, gamma-, and neutron irradiation. Dr. Stankus was very interested in the establishment of an IEI office. He said that the Soros Foundation has been very helpful in supporting scientists, but he was somewhat disappointed with the level of support; each scientist receives about $\$ 200$ to $\$ 250$, with some larger grants awarded to purchase Western journals and to support academicians. He looked over the focus areas taken from the Hanford needs statement and said he would think about areas in which his institute is involved.

\subsubsection{Assessment}

The ITP could not be thoroughly assessed owing to the brief and limited visit. The work of Dr. Stankus is very impressive. The equipment with which he works is a blend of well machined apparatus and outdated computerization. For example, the apparatus shown in Figure 2.9 is typical of that found in many academic laboratories in the U.S. However, the bank of computer equipment that probably would occupy one tenth the space in the U.S. is not shown.

\subsubsection{Possible Collaborations}

Measurement of Densities by Absorption of Cs-137 Gamma Rays

Russians: $\quad$ Dr. Sergei V. Stankus

Americans: Westinghouse Hanford Company Vitrification Plant

\subsection{Institute of Mathematics}

\subsubsection{Dr. Aleksandr M. Blokhin}

Dr. Blokhin, Chairman of the Department of Differential Equations at the Institute of Mathematics (IM), has been working with differential equations and solving them on a theoretical basis. He is the editor of the Siberian Journal of Differential Equations. He and one of his coworkers filled out SABIT applications and gave them to me before I left Novosibirsk.

\subsubsection{Assessment}

The IM could not be assessed during the brief visit that $I$ had with Dr. Blokhin. The level of Dr. Blokhin's presentation was so sophisticated that I could not judge the validity of his mathematical explanations. He was very enthusiastic about his work. 


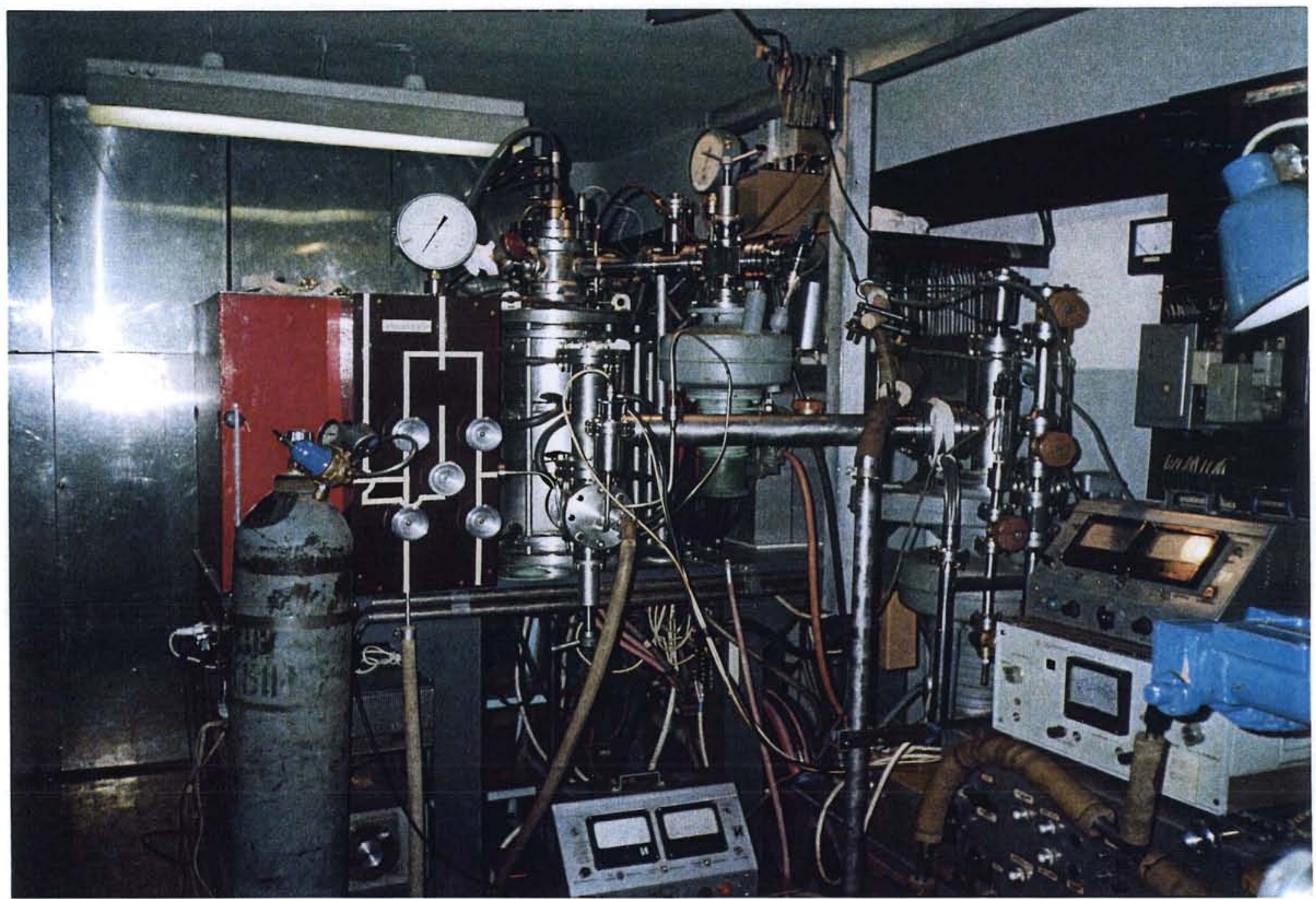

Figure 2.9. Apparatus for Measuring Density Changes at High Temperature Using Absorption of ${ }^{137}$ Cs Gamma Rays at the Institute of Thermal Physics, Novosibirsk, Russia 



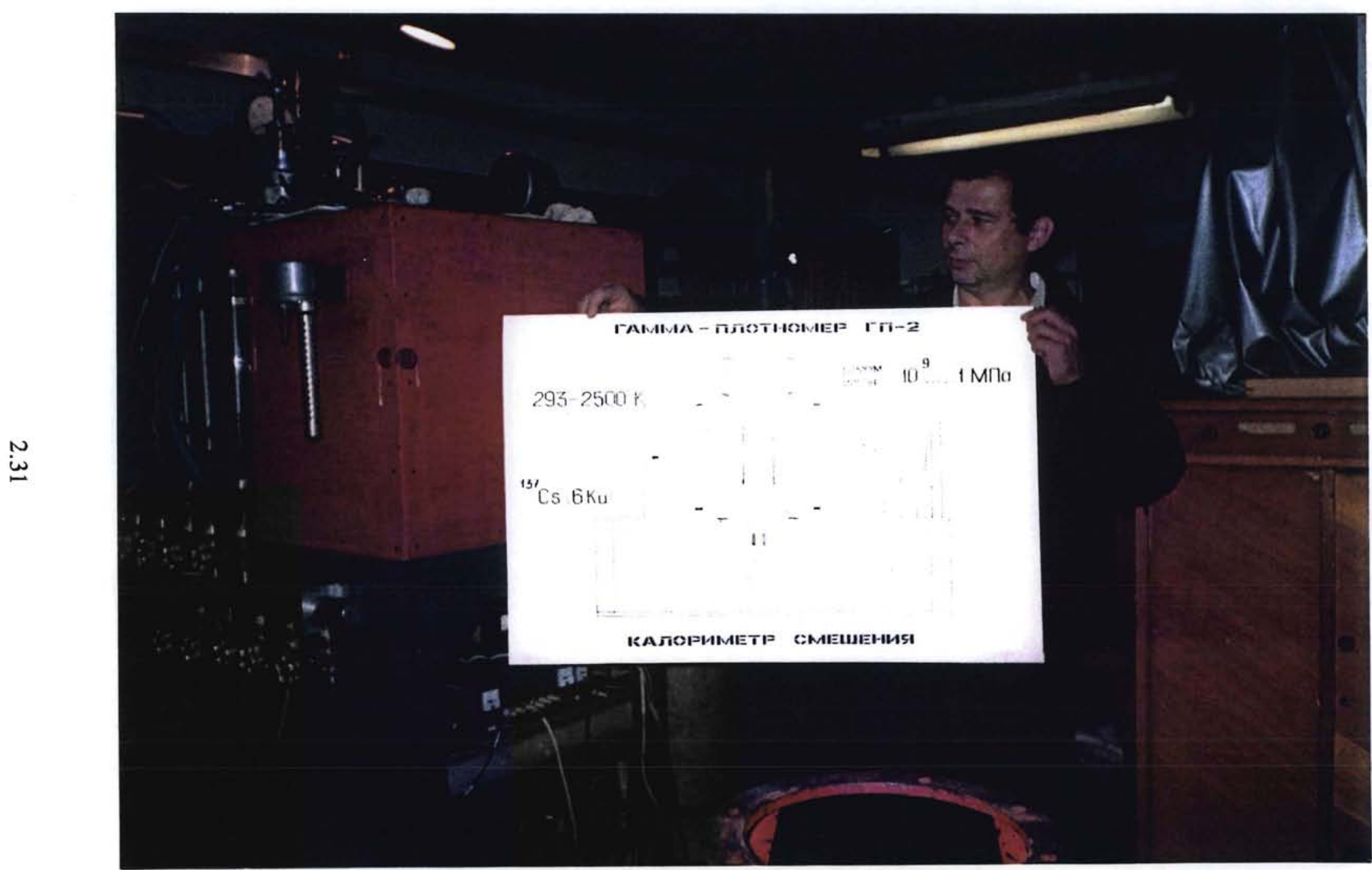

Figure 2.10. Dr. Sergei Stankus with a Diagram of His Apparatus for Measuring Densities at the Institute of Thermal Physics, Novosibirsk, Russia 


\subsubsection{Possible Collaborations}

\section{Solution of Differential Equations}

Russians: $\quad$ Dr. Aleksandr M. Blokhin

Americans: Applied Physics Center at PNL

\subsection{Siberian Branch All-Russian Scientific-Research Planning Institute of Energy Technology}

\subsubsection{General Description}

This is basically a design bureau that is involved in projects at Krasnoyarsk and Tomsk, among others. Krasnoyarsk is facing problems similar to those at the Hanford Site, in particular, waste tanks and environmental contamination. This institute designed equipment for wet and dry processing of aerosols and dust. In addition, they designed equipment for catalytic destruction of impurities in gases. They work in conjunction with several of the institutes in Akademgorodok, in particular, the Institutes of Catalysis, Nuclear Physics, Geology and Geophysics. The parent organization is based in St. Petersburg. The Novosibirsk Division has branch offices in Tomsk, Krasnoyarsk, and other cities. In the past, the Division has been supported by the military. At present, the military has ceased to order equipment from VNIPIET. The organization is existing on orders from industry; however, the financial situation is generally very poor. They would be willing to work with Western companies.

\subsubsection{Drs. Yurii V. Ostrovskii, Boris I. Lunyushkin (Vice Chief Engineer), and Sergei M. Boboedov (Chief Engineer)}

These three scientists gave an impressive presentation with detailed diagrams of the equipment they designed for the above tasks. Although they have designed much equipment, there are few demonstration projects in operation. They mentioned that they have had equipment in operation at Tomsk and Krasnoyarsk. Another interesting aspect of this branch of the bureau is that the parent organization is in St. Petersburg.

\subsubsection{Possible Collaborations}

Design of Equipment for Treating Off-gases

Russians: Dr. Yurii V. Ostrovskii

Dr. Sergei M. Boboedov

Dr. Boris I. Lunyushkin

Americans: Engineering Technology Center at PNL

(Off-gas problems, Chuck Allen et al.)

Other PNL Staff 


\subsection{Institute of Cytology and Genetics}

\subsubsection{General Description}

Professor Rudol'f I. Salganik, Head of the Department of Molecular Genetics and Deputy Director of the Institute of Cytology and Genetics (ICG) said that ICG is working on two projects related to radiation effects. The first project involves following the genetic patterns of second- and thirdgeneration descendants of people affected by the Chelyabinsk accident. Genetic abnormalities in the descendants can be identified by using DNA fingerprinting. The second project is a study of the susceptibility of individuals to certain known cancer-causing substances in the environment. It has been discovered that certain genetic markers are indicative of susceptibility to particular substances. Thus, there may be a basis for selecting workers that will be exposed to known carcinogens. In another project, specific bacteria and other organisms are being developed as biosensors for organic substances in soil and water.

\subsubsection{Dr. Gafur A. Zainiev}

Dr. Zainiev is personally working on methods of stretching DNA and finding the breaking point. He has isolated bundled DNA from mosquito larvae and developed a method for stretching it and measuring the strength.

\subsubsection{Assessment}

The ICG could not be accurately assessed during the brief visits; however, my discussion with Dr. Salganik was very interesting. The institute's work could be significant to those concerned about the effects of releases from Hanford on the surrounding population. In addition, some of their results may be useful in screening workers for high-radiation environments.

\subsubsection{Possible Collaborations}

\section{Genetic Markers and DNA Fingerprinting}

Russians: $\quad$ Dr. Rudolf I. Salganik

Americans: Molecular Sciences Research Center at PNL

Life Sciences Center at PNL

(Brian Thrall)

Other PNL Staff 


\subsection{Institute of Organic Chemistry}

\subsubsection{General Description}

The Assistant Director of the Institute of Organic Chemistry (IOC), Professor Vladislav M. Vlasov, explained the four principal directions of the IOC (all of which are outlined in a brochure that he promised to provide me). The areas are 1) ecological problems associated with paper and pulp production in Siberia, 2) creation of databases for analysis of organic compounds, 3) the study of various aspects of the chemistry of aromatic and heterocyclic compounds, and 4) the investigation of natural compounds.

\subsubsection{Dr. Boris G. Derendyaev}

Dr. Derendyaev is the Head of the Scientific and Technical Center of Chemical Informatics, which analyzes complex organic mixtures. The analyses are performed using gas chromatography-mass spectrometry (GC-MS), nuclear magnetic resonance (NMR), EPR, IR, ultraviolet (UV), and other conventional analytical methods. Their equipment is not state-of-the-art, by his own admission, but is of late 1980 s vintage. They are very much concerned with ecological problems such as organic contamination of the Semipalatinsk nuclear test site in Kazakhstan and pollution from paper mills surrounding Lake Baikal, the world's largest source of fresh water. They have created databases for IR, UV, NMR, MS, and other analytical techniques that complement those databases available in the West, for example, the databases at the National Institute for Standards and Technology (NIST). In fact, his center shares data with NIST. They have two libraries in the IOC, one contains volumes of spectral data, such as the Sadtler indices. The other is a new library directed toward ecological problems. The first is shown in Figure 2.11. The IOC is de facto directed by Academician Koptyug, the President of the Siberian Division of the RAS. The fact that the IOC has become interested in environmental problems results from the fact that the Academician Koptyug is personally interested in such problems. In addition, there was a very impressive demonstration of the database containing MS data and how this database can be used in conjunction with NMR and other data to suggest most probable structures of unknown compounds. The computer and graphics were comparable to the best I have seen in the West.

\subsubsection{Associate Professor Victor M. Tormyshev}

Professor Tormyshev discussed Novosibirsk University, where he has been teaching for about 20 years. The University accepts only very talented students. The normal course of study spans five years. The first three years are spent in the classroom covering classes that are normally covered in five years in other universities. This is apparently very demanding on the students since the dropout rate (voluntary and involuntary) is about $1 / 3$. The last two years of study are spent conducting research at the various institutes in Novosibirsk. I was surprised to learn that most of the best students find employment in the West. I was even more surprised to learn that Professor Tormyshev is agreeable to the students going abroad to work when he knows that most of them will not return to Russia. His reasoning is that the future of science in Russia is definitely in doubt and that there is no guarantee that students remaining in Russia to work will find future support. They most likely will be 


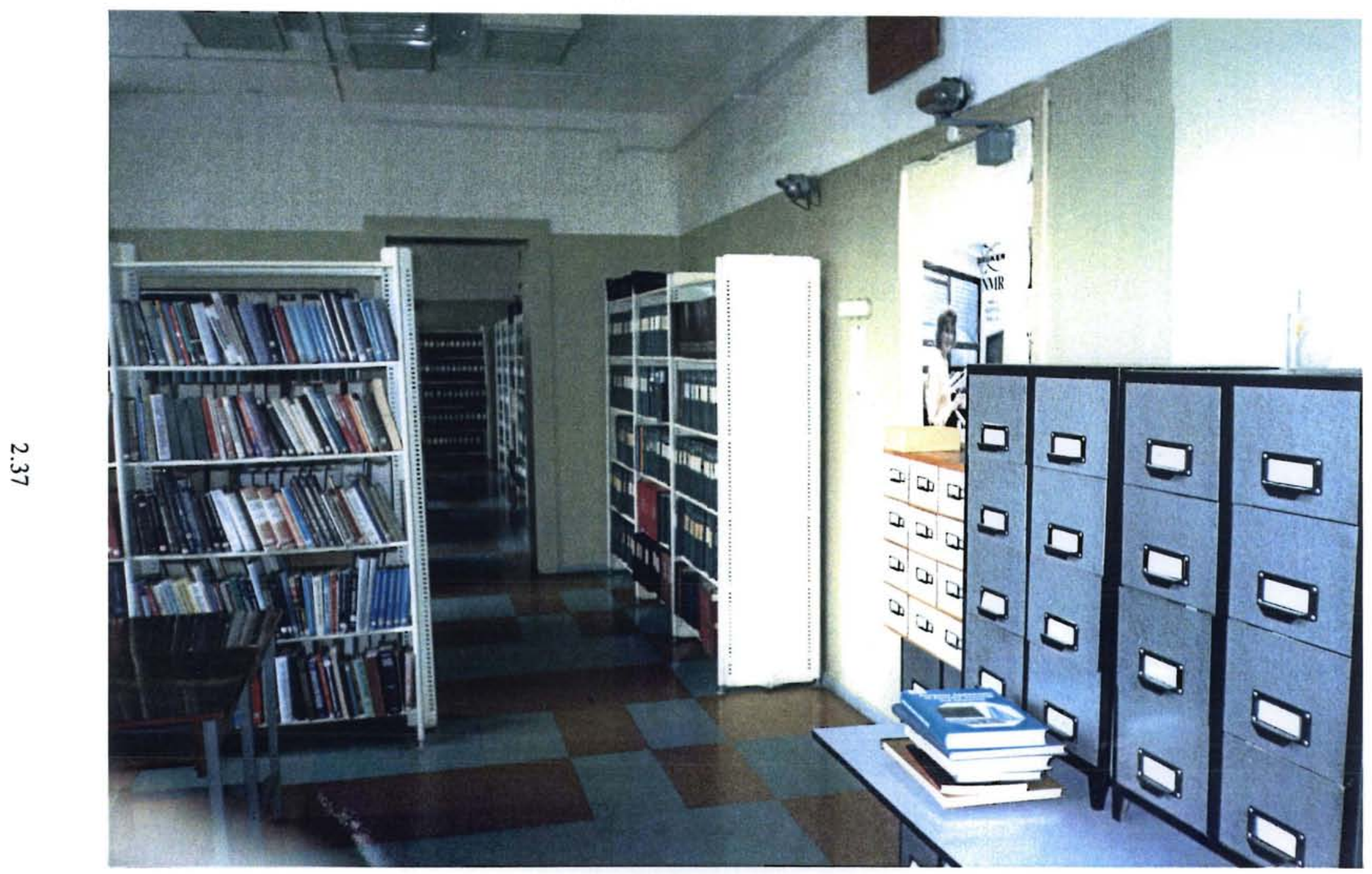

2.11. Library of Spectral Data at the Institute of Organic Chemistry, Novosibirsk, Russia 

forced to find work in other sectors of the economy. Thus, it would be better for them to work in the West and maintain their careers in science than to remain in Russia and be forced out. He was of the opinion that the Russian students are of a higher caliber than Western students since there are not as many diversions in Russia.

\title{
2.8.4 Assessment
}

The IOC was the most modern institute that I visited in Novosibirsk. The influence of Academician Koptyug was clearly evident in the establishment of an ecological library and in the involvement with ecological problems. The Scientific and Technical Center of Chemical Informatics is a very impressive operation that is studying problems that could directly impact Hanford issues, for example, characterization of organic compounds in the storage tanks. The library on environmental problems is a timely idea. However, it is still very small with few volumes, although it apparently is growing rapidly. The computer program to identify compounds using a combination of spectra should be of interest to the best Western laboratories.

\subsubsection{Possible Collaborations}

\author{
Analysis of Complex Organic Mixtures, Computer Processing of Spectral Data \\ Russians: Dr. Boris G. Derendyaev \\ Americans: Materials and Chemical Sciences Center at PNL \\ Engineering Technology Center at PNL \\ Other PNL Staff
}

\subsection{INEK Corporation (Siberian Research Power Institute)}

\subsubsection{General Description}

Dr. Igor' T. Ovchinnikov, Head of the Laboratory of High-Voltage Biophysics, and Sergei P. Shul'zhenko, General Director of the Scientific Production Association INEK in Novosibirsk explained that INEK collaborates with several institutes in Novosibirsk, in particular, the Institute of Physiologically Active Substances.

\subsubsection{Dr. Igor' T. Ovchinnikov}

Dr. Ovchinnikov, Chief of the High-Voltage Biophysics Laboratory, has developed several interesting apparatuses. The first is a microscan instrument that uses a laser to scan water samples. This instrument is shown in Figure 2.12. The interference patterns of the laser are processed by computer using a program that was written onsite. The resulting data can be used to determine what kind of particle is responsible for the interference, for example, whether that particle is a bacterium or mineral particle. In addition, the data are sufficiently reliable to determine whether the bacterium is living or dead. The method can be used to monitor drinking water and determine in about two or three hours whether that water is contaminated by living bacteria. 



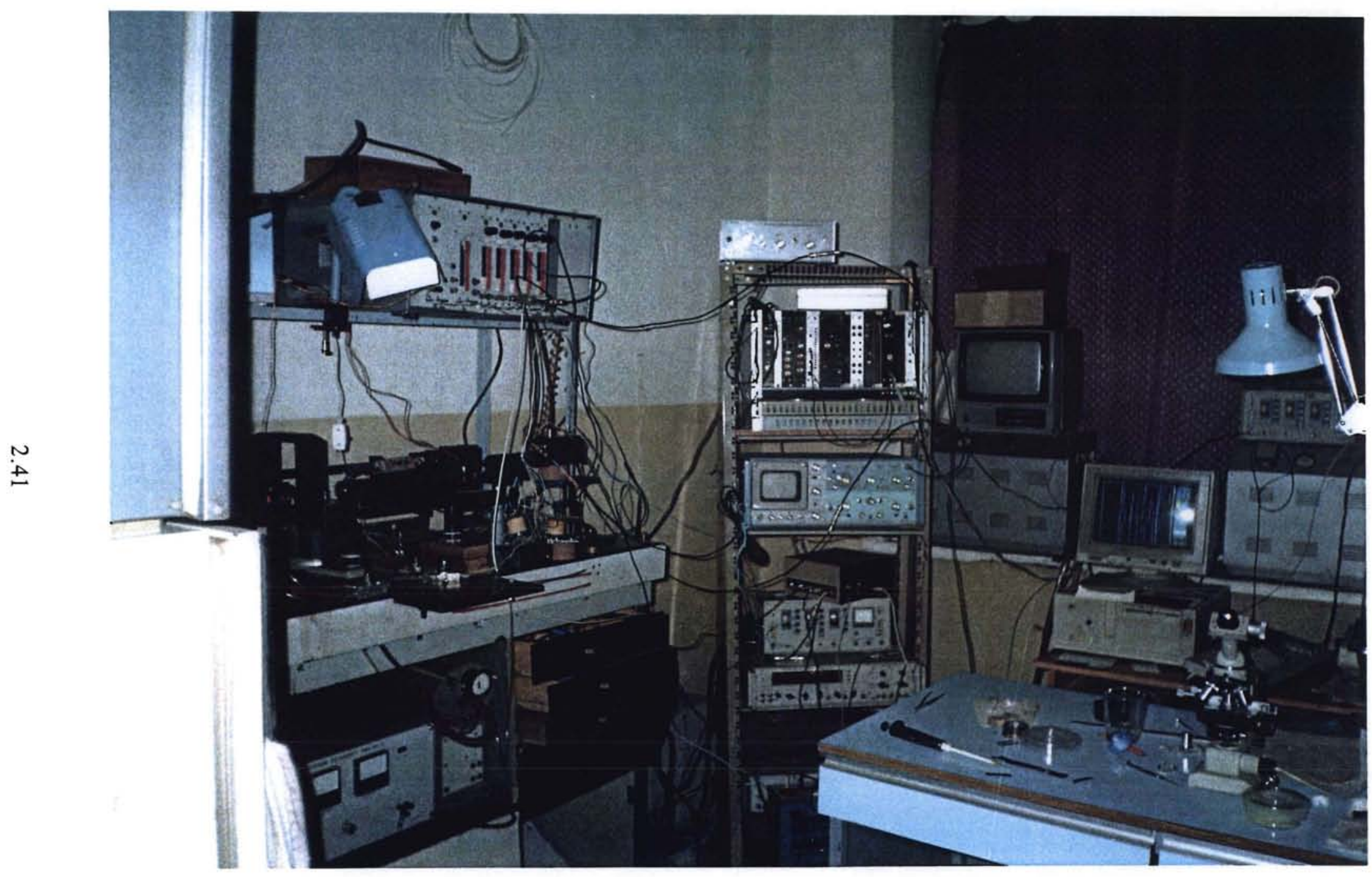

Figure 2.12. Laser Microscanner Used to Detect Bacterial Contamination of Water at the High-Voltage Biophysics Laboratory, Siberian Research Power Institute, Novosibirsk, Russia 

Dr. Ovchinnikov's second invention is a bioreactor that electrolyzes water with very short and very powerful electrical impulses. The laboratory-scale test model of this reactor is shown in Figure 2.13. A pilot-scale reactor was also housed in INEK. The bioreactor can be used to kill bacteria living in the water. Used in conjunction with the microscan, the system could be used to sterilize drinking water and monitor the sterility. A pilot-scale bioreactor can sterilize water at the rate of 1,000 cubic meters per hour. The third invention involves a bacterium that was discovered living in wastewater from industrial and domestic sources. The bacterium exhibits the unique property of acting as an ion exchanger for heavy metals. The bacterium is being grown in quantity for further testing. Not many details of this project were provided.

\subsubsection{Assessment}

The technology presented at INEK was very interesting. They have essentially developed methods to sterilize water without using chemicals and to monitor water purity with respect to bacterial contamination using a method that can yield results within minutes as opposed to methods currently used in the West that require hours or even days. It was difficult to see how this technology would fit into the master plan for Hanford. However, it also seemed so novel, useful, and ecologically benign that there would probably be some American company that would be interested in commercializing it. The equipment and instrumentation at INEK seemed to be of high quality and rather recent design.

\subsubsection{Possible Collaborations}

\section{Water Sterilization and Monitoring}

Russians: $\quad$ Dr. Igor' T. Ovchinnikov

Americans: Life Sciences Center at PNL

Tri-City Industrial Development Council 



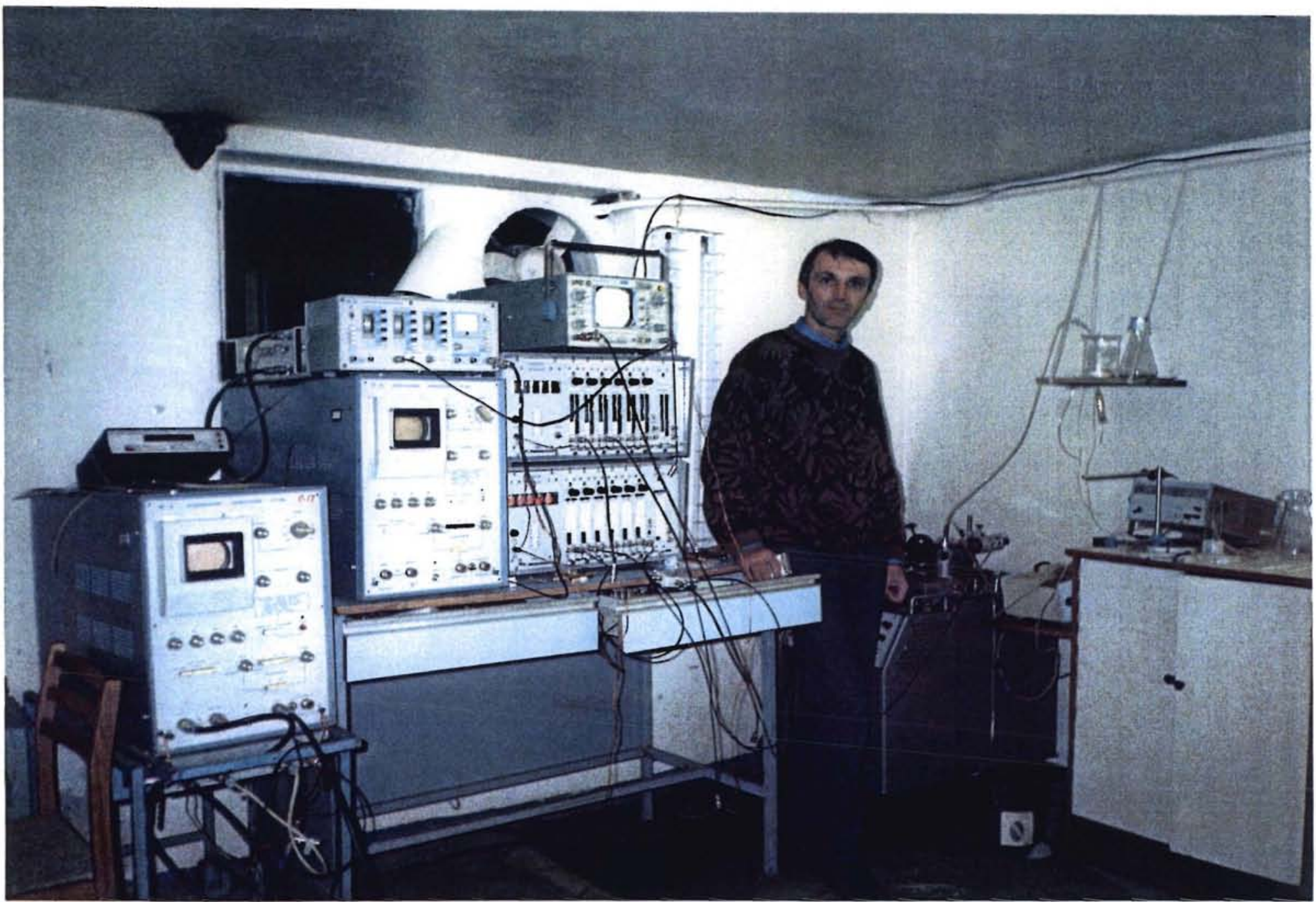

Figure 2.13. Dr. Igor Ovchinnikov and the Laboratory-Scale Bioreactor for Water Sterilization at the High-Valtage Biophysics Laboratory, Siberian Research Power Institute, Novosibirsk, Russia 


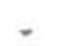

. 


\subsection{Ufa}

\subsection{Novoil Refinery}

\subsubsection{General Description}

The main purpose of the trip to Novoil Refinery was to view the IC pilot plant. Officials of the Novoil New Ufa Oil Refinery, the largest oil refinery in Europe, include Foad R. Ismagilov and Nur R. Saifullin, Director for Reconstruction and Development. The refinery is undergoing reconstruction to make it more environmentally compatible. However, even though the refinery makes a profit of more than $\$ 100 \mathrm{M}$ per year, its management is still in search of credit to finance the reconstruction. They stressed that they are ignorant of how to obtain such financing and would be willing to pay a finder's fee to any organization willing to help. They suggested that this may be a project that the IEI could work on since the reconstruction is mainly directed at making the refinery an environmental showplace. Vladislav Oschepkov of the Foreign Trade Department listed the following questions about such credit: amount of credit, rate, commission for the finding organization, payback time and schedule, guarantee, type of credit, required documentation, granting of credit. Vladimir N. Karakuts, the plant general director, discussed the environmental problems facing the plant, most are related to sulfur in the feedstocks.

\subsubsection{Assessment}

Owing to my limited experience with oil refineries, I have no means for comparing this refinery with those in the West. The refinery was very expansive, covering dozens of acres with towers, tanks, and stacks. The grounds of the refinery were generally clean, although some spots were obviously contaminated with petroleum products.

\subsubsection{Possible Collaborations}

\section{Reconstruction of the Largest Oil Refinery in Europe} Russians: Officials of Novoil Refinery

Americans: International Environmental Institute

\subsection{Ufimskii Aviation Institute (UAI)}

\subsubsection{General Description}

Dr. Flyur R. Ismagilov, Senior Scientific Associate, explained that the Ufimskii Aviation Institute (UAI) is a production institute that has traditionally been involved with the production of aircraft in the former Soviet Union, specifically, airplane engines and electrical systems. One item of interest is a portable generator that uses wind power. It is useful to small parties such as research groups, hunters, campers, etc. It has a nominal power of $0.25 \mathrm{~kW}$ at a wind speed of $7 \mathrm{~m} / \mathrm{sec}(\sim 16 \mathrm{mph})$. 


\subsubsection{Assessment}

The portable wind generator appears to be an innovative idea that could catch on in the West and become very popular with outdoorsmen, farmers, or research parties. It would be interesting to determine if such an idea has been commercialized or patented. If not, this could be the basis of a small business in the Tri-Cities.

\subsubsection{Possible Collaborations}

Portable Wind Powered Generator

Russians: Dr. Flyur R. Ismagilov

Americans: Tri-Cities Industrial Development Council

\subsection{Bashkir State University}

\subsubsection{General Description}

Bashkir State University is located in Ufa.

\subsubsection{Dr. Florida K. Kudasheva}

Dr. Kudasheva, Head of the Department of Analytical Chemistry and Technology of the Bashkir State University is collaborating with a British firm called Emerald to make ion-exchange filters for purifying groundwater (Figure 3.1). The university is particularly interested in removing strontium, lead, and other ions from the water. Dr. Kudasheva did not explain the principle behind the ionexchange filters other than to say that they are organic resins.

\subsubsection{Assessment}

The cartridges developed in collaboration with Emerald were very interesting, since plans to remove cesium and strontium from Hanford wastes could very well use such cartridges packed with ion-exchange materials developed domestically. In particular, membranes and webs being developed by $3 \mathrm{M}$ in collaboration with PNL would fit very nicely into the cartridges.

\subsubsection{Possible Collaborations}

Ion-exchange Cartridges and Materials

Russians: Dr. Florida K. Kudasheva

Americans: U.S. Department of Energy

Materials and Chemical Sciences Center at PNL

(Lane Bray and Dennis Wester) 


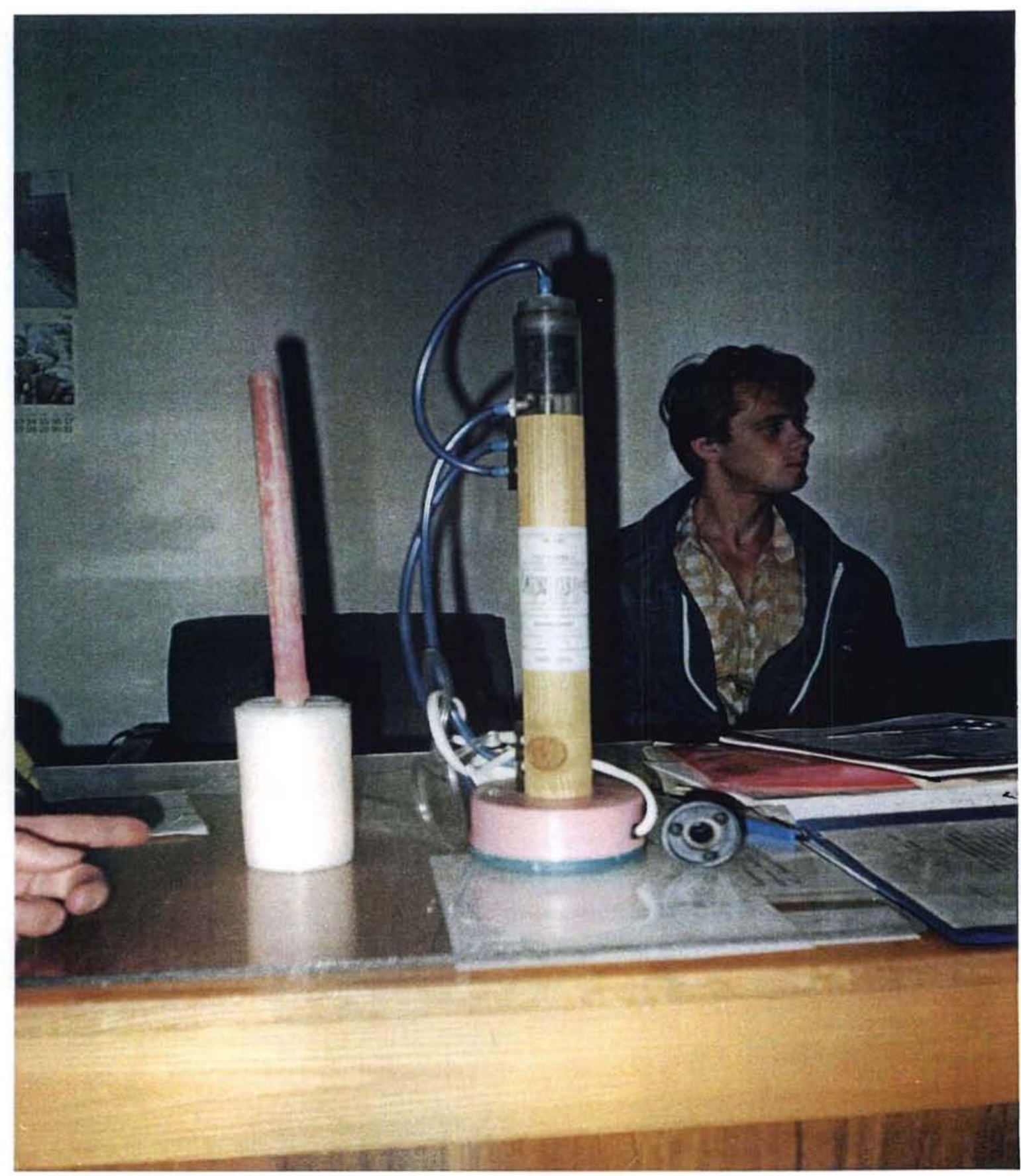

Figure 3.1. Ion-Exchange Column and Cartridge Fabricated at the Department of Analytical Chemistry and Technology, Bashkir State University, Ufa, Russia 


\subsection{Kemerovo}

\subsection{TOKEM Company}

\subsubsection{General Description}

Dr. Aleksandr A. Moroz of TOKEM (Tovary Kemerovo) company in Kemerovo explained that TOKEM is the new name of the privatized company KARBOLIT that operated in Kemerovo. The name was changed since the KARBOLIT plant in European Russia was privatized first and retained that name. The chief product of TOKEM is phenol-formaldehyde polymers. The company modifies the polymer to make ion-exchange resins. They have been working on some new resins, of particular interest is one that is selective for rhenium, an analog of technetium. (They were unsure of the adsorbed form of rhenium.) TOKEM is also working on new thiourea resins that are useful for extracting mercury and silver. In addition, they produce several well known resins that have been tested with radionuclides such as $\mathrm{Sr}^{2+}$ and $\mathrm{Cs}^{+}$by Vladimir Gelis in Moscow (see below). In general, the ion-exchange resins are the standard strong-acid sulfonated and strong-base tertiary amine type.

\subsubsection{Assessment}

The activity of the TOKEM plant has dwindled owing to the loss of government orders. Nevertheless, there seems to be a core of very enthusiastic workers that is pushing ahead with new and improved products. The Kemerovo area is known as one of the most polluted in Russia, so TOKEM is struggling with environmental problems related to the wastes from their production. The new resins being produced there should be tested in the West to determine their effectiveness for removing certain metal ions. Their effectiveness should then be compared with the best materials available here.

\subsubsection{Possible Collaborations}

\section{Ion-exchange Resins}

Russians: TOKEM Company

Americans: EM-50 at PNL

Efficient Separations and Processing Integrated Program at PNL

(Lane Bray)

Other PNL Staff

\subsection{Kemerovo State University}

\subsubsection{General Description}

Kemerovo State University is situated in the center of Kemerovo. I believe it is supported by local industries and governments. Among the departments at the university, the chemistry department seemed to occupy a large portion of the best building. 


\subsubsection{Professor Sergei M. Ryabyk}

I visited two staff members of Kemerovo State University. Of particular interest was the work of Professor Sergei M. Ryabyk of the Department of Solid-State Chemistry. He has prepared a document on the environmental situation of the Kuzbass (Kuznetskii Bassein). The problems of the region are largely the result of pollution by coal mines and steel mills. The coal mines generate dust and contaminated water, which pollute the groundwater and surface water. The steel mills are located in Novokuznetsk, upriver from Kemerovo.

The epidemiological data published in Professor Ryabyk's document for the Kuzbass are very disturbing. The average expected lifespan of males (54 years) in the region is six years less than the average for all of Russia. In addition, there are problems with a large percentage of the births; the health of the children is quite poor.

We toured several laboratories in the Chemistry Department. Overall, they were the most well equipped laboratories that I had seen to date in Russia. The glassware, instrumentation, and computerization were all adequate for a teaching situation. The computer laboratory, which was well equipped with several of the latest personal computers is shown in Figure 4.1.

\subsubsection{Possible Collaborations}

\section{Environmental Assessments}

Russians: $\quad$ Professor Sergei M. Ryabyk

Americans: Westinghouse Hanford Corporation

U.S. Department of Energy

\subsection{Institute of Coal, Siberian Division of the RAS}

\subsubsection{General Description}

The Institute of Coal in Kemerovo was established to support the extensive mining in the Kuzbass. The Institute is involved in coal production, from the development of the mines to the delivery of dried product.

\subsubsection{Gennadii I. Gritsko, Aleksandr B. Logov, et al.}

The principal people were Gennadii I. Gritsko (Corresponding Member, RAS, Director of the Institute), Professor Aleksandr B. Logov (Vice Director), Candidate Oleg V. Tailakov (Scientific Secretary), and Cand. Vsevolod M. Stankus (mining engineer), who invited me to visit the institute. They explained that there are many environmental problems associated with coal production. 
$\stackrel{+}{\text { in }}$

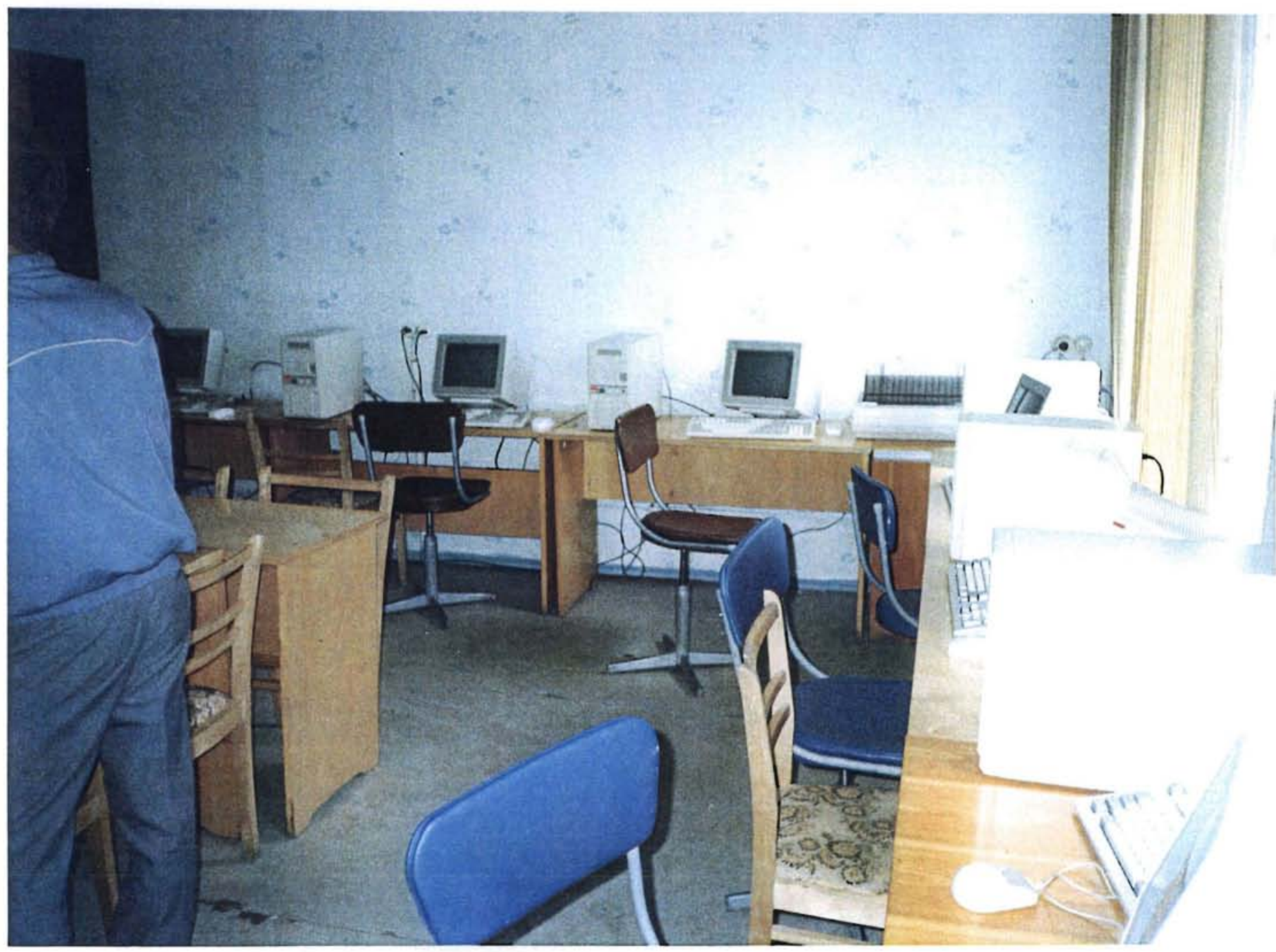

Figure 4.1. Computer Laboratory at Kemerovo State University 
Dr. Gritsko has visited Australia and Brazil to see how coal is produced in those countries. In addition, he has contacts at Pennsylvania State University, the University of Pittsburgh, and in many coal-producing countries throughout the world.

One member of the institute was involved in addressing environmental problems. He mentioned that there are several means by which the institute is addressing these problems. One solution is to dry the dust and make pellets out of it. It is too friable to make briquettes. Another solution is to reduce the amount of methane released from the mines by using an adsorbent in the mine or condensing the methane at the mine opening and then using this methane to produce heat energy.

\subsubsection{Assessment}

In general, the Institute is in poor financial condition. They need capital to implement their solutions. The institute has been very aggressive in making contacts in the West. The environmental problems of the region are well known throughout Russia.

\subsubsection{Possible Collaborations}

\section{Production of Coal and Associated Environmental Problems}

Russians: Dr. Gennadii I. Gritsko

Professor Aleksandr B. Logov, et al.

Americans: U.S. Department of Energy Program on Coal

(Gary Dyrkacz, Argonne National Laboratory) 


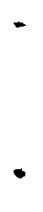




\subsection{Ulan Ude}

\subsection{Geological Institute, Buryat Branch, Siberian Division of the RAS}

\subsubsection{Dr. Alexander L. Kovalevskii}

Dr. Alexander L. Kovalevskii of the Geological Institute, Buryat Branch, Siberian Division of the RAS, has spent more than 20 years studying the biogeochemistry of Russian plants and aquatic life in Lake Baikal. He has recently published a book on the biogeochemistry of plants, a copy of which I was able to obtain. Dr. Kovalevskii has studied the accumulation of mercury in fish of Lake Baikal. He discovered that the mercury in Lake Baikal results from seismic activity at the bottom of the lake. The mercury is carried to the surface waters by convection. Dr. Kovalevskii is responsible for millions of analyses for about 50 elements in hundreds of plant species. He has previously researched the accumulation of uranium by plants and has recently become interested in the accumulation of strontium and cesium by plants.

\subsubsection{Assessment}

The work of Dr. Kovalevskii is little known in the West. His expertise includes numerous years of data collection and analysis. The methods used by Dr. Kovalevskii in his studies may be of interest to those at Hanford researching similar topics.

\subsubsection{Possible Collaborations}

\section{Biogeochemistry of Plants}

Russians: Dr. Alexander L. Kovalevskii

Americans: $\quad$ Earth and Environmental Sciences Center at PNL

(Peter Van Voris, Ray Wildung) 


\subsection{St. Petersburg}

The visit to St. Petersburg was brief. For example, the headquarters of VNIPIET (the Novosibirsk branch office was visited) could not be located. In addition, the visit to the Radium Institute was abbreviated since many key personnel were in America during that week. However, since DOE has a contract with the Radium Institute, and several PNL staff members are familiar with the work going on there, this absence was not a serious shortcoming.

\subsection{St. Petersburg State University}

\subsubsection{General Description}

St. Petersburg State University is one of the oldest universities in Russia. It was originally located near the center of St. Petersburg. Most of the departments are still on this campus; however, in recent years the University has expanded into the suburbs surrounding St. Petersburg.

The campus of St. Petersburg State University at Peterhof houses the departments of chemistry, physics, and mathematics. The students live in dorms onsite. Teachers for such subjects as philosophy, political science, etc., travel to the campus to give their courses.

\subsection{Department of Chemistry}

\subsubsection{Dr. Alexei Yu. Ershov}

Dr. Ershov is a Senior Scientist at St. Petersburg State University in the Department of Chemistry. We spent two hours each way traveling to Peterhof to tour the new chemistry building. The building was indeed very impressive, the most modern building that I had seen in Russia. The labs were well equipped; typical scenes in the laboratories of the new chemistry building are shown in Figure 6.1, 6.2 , and 6.3. The lecture rooms were very modern. The building even contained a gym and locker rooms for the faculty. Dr. Ershov is investigating the chemistry of luminescent metal complexes containing bridging ligands that facilitate electron transfer between metal centers.

\subsubsection{Assessment}

Much of the expertise in the Department of Chemistry may be useful to Hanford, but during my brief visit, I was unable to adequately assess the extent of this. The work of Dr. Ershov is of definite interest to the catalyst group in PNL, as evidenced by the invitation to him from Michael Lilga to participate in the SABIT program at PNL under the sponsorship of laboratory-directed reserach and development (LDRD). 
$\bullet$ 


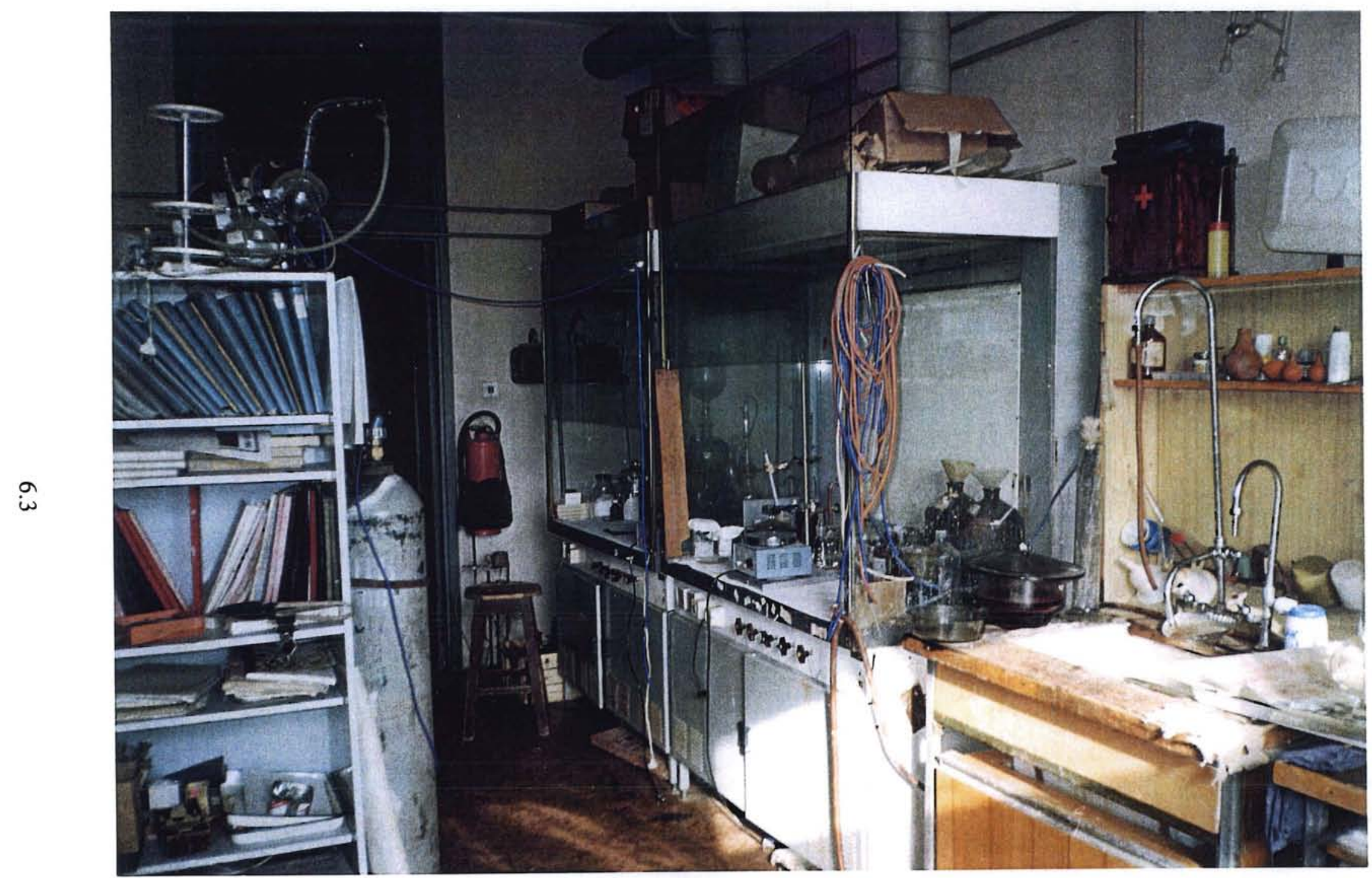

Figure 6.1. One-Person Chemistry Laboratory in the New Building at St. Petersburg State University 



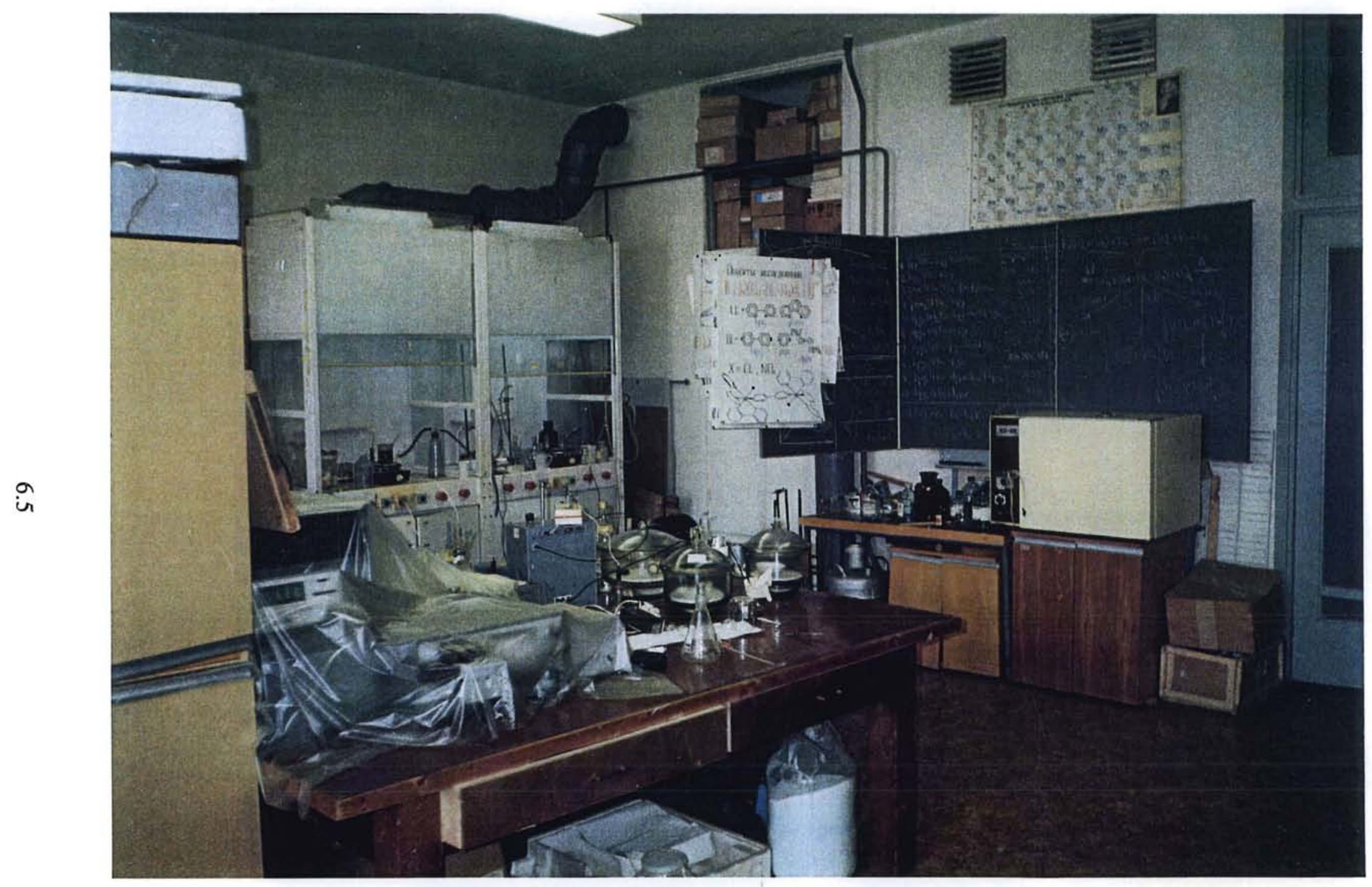

Figure 6.2. Multiperson Chemistry Laboratory in the New Building at St. Petersburg State University 


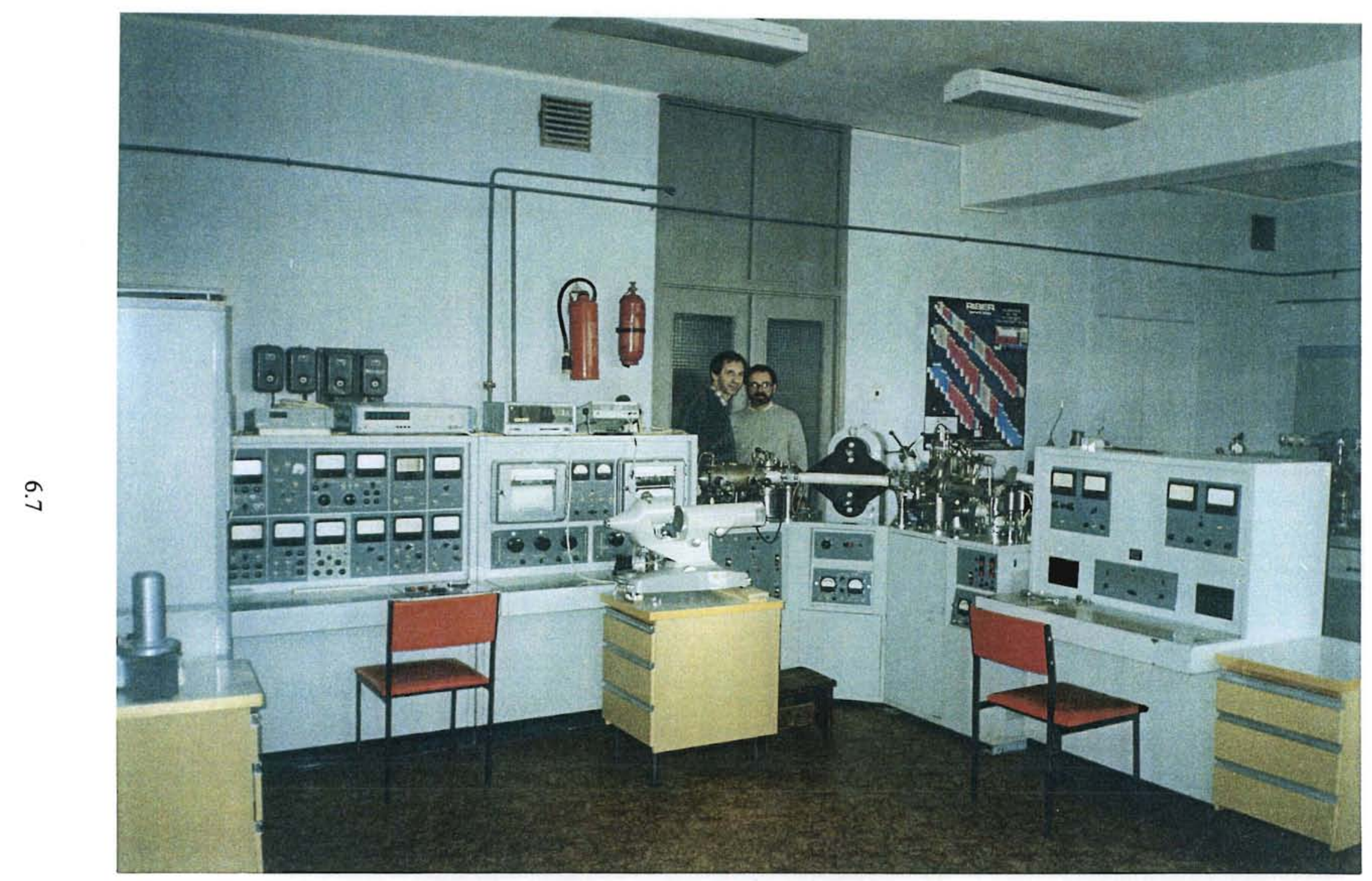

Figure 6.3. High-Resolution Mass Spectrometer in the New Building at St. Petersburg State University 


\title{
6.2.3 Possible Collaborations
}

\author{
Luminescent Bridged Metal Complexes \\ Russians: Dr. Alexei Yu. Ershov \\ Americans: Catalyst Group at PNL
}

(Mike Lilga)

\subsection{Department of Radiochemistry}

\subsubsection{General Description}

The Radiochemistry Department at St. Petersburg State University consists of several laboratories. These include Radiochemical Analysis, Actinides and Lanthanides, Nuclear Chemistry, Extraction and Extraction Chromatography, Chemical Sensors (Semiconducting and Ion-Selective), Environmental Nuclear Chemistry, and Nuclear Chemical Processes. The department is housed partly in the "old" chemistry building in St. Petersburg and partly in the new building in Peterhof. The faculty and students prefer the old chemistry building since commuting in Russia is time consuming. This is the building where most of the workers at Khlopin Radium Institute got their start. The Radiochemistry Department is located in one wing of the building. The other wing houses the Leningrad Filial of the Russian Chemical Society, which has a very modern office.

\subsubsection{Dr. Yurii F. Batryakov}

Dr. Batryakov works with Lev L. Makarov. Dr. Batryakov is a very enthusiastic scientist who uses XPS to probe the bonding in chemical compounds. In his work with the compounds of the uranium-oxygen system, several fundamental advances have been made in explaining the structurebonding relationships in this highly complicated system. The model that has been developed can be used to determine the oxidation state of uranium in natural objects, such as minerals and soil. The laboratory has also studied technetium compounds. Dr. Batryakov has two XPS spectrometers that provide resolution better than any other in the world. The instrument and Dr. Batryakov are shown in Figure 6.4. The high-resolution data enables him to determine structures with a high degree of precision.

\subsubsection{Dr. Yurii E. Ermolenko}

Dr. Ermolenko works in the Laboratory of Ion-Selective Electrodes. The laboratory researches these electrodes and produces them for commercial sale by a firm called Potential. Dr. Ershov said that he has used the electrodes in his research and found them to be very stable and reliable. Mini electrodes have been prepared for blood analysis. Among the electrodes offered for sale are those for $\mathrm{K}^{+}$, $\mathrm{NH}_{4}^{+}, \mathrm{NO}_{3}^{-}, \mathrm{ClO}_{4}^{-}, \mathrm{CO}_{3}^{2-}, \mathrm{Ca}^{2+}, \mathrm{Ba}^{2+}, \mathrm{Ca}^{2+}+\mathrm{Mg}^{2+}, \mathrm{NO}_{2}^{-}$, and $\mathrm{CrO}_{4}^{2-}$. Several of the electrodes produced by this laboratory are shown in Figure 6.5. Dr. Ermolenko uses the electrodes to monitor waste water and natural systems. 


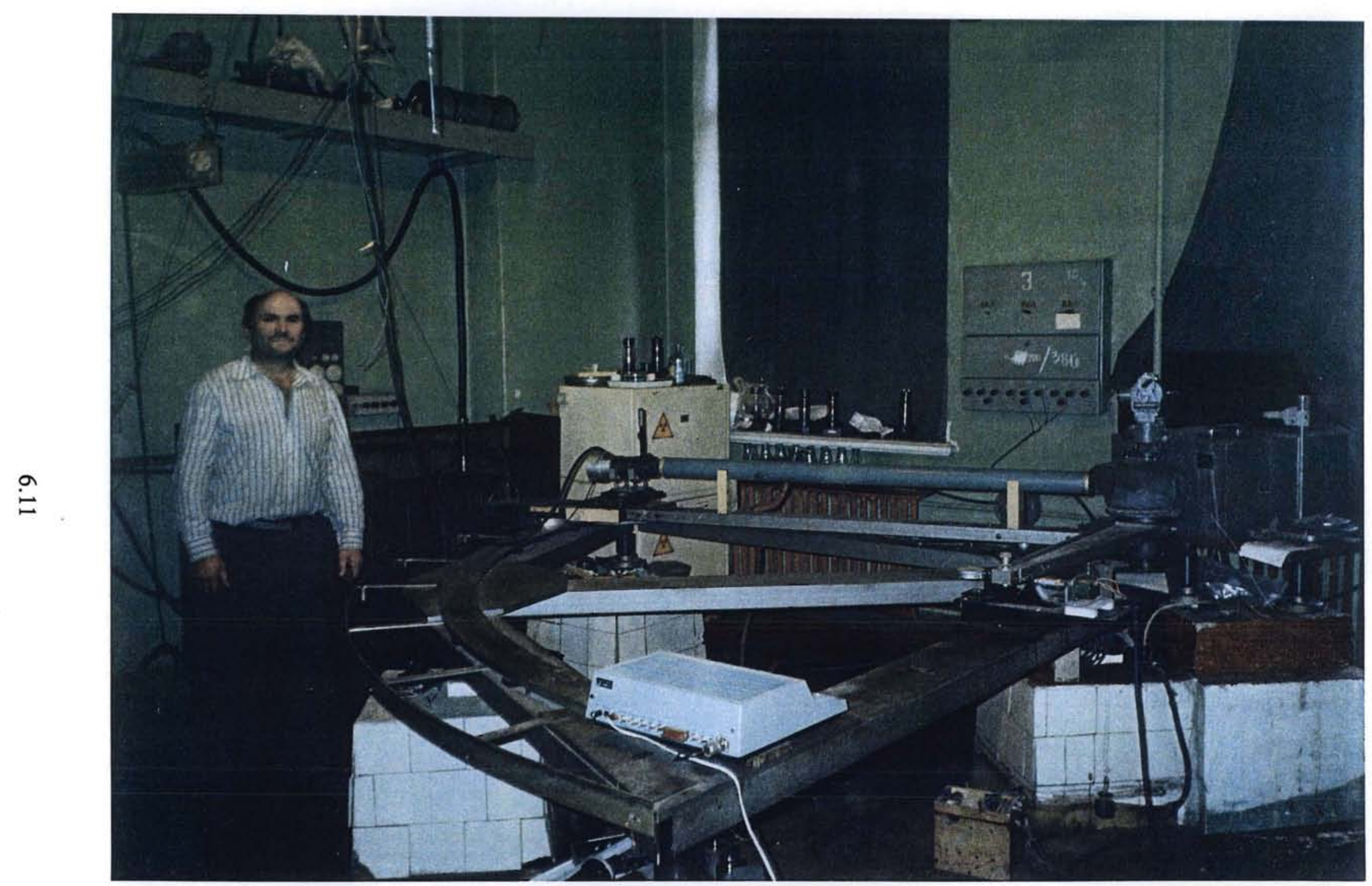

Figure 6.4. Dr. Yurii Batryakov and his High-Resolution XPS Spectrometer at the Radiochemistry Department, St. Petersburg State University 
$-$

. , 


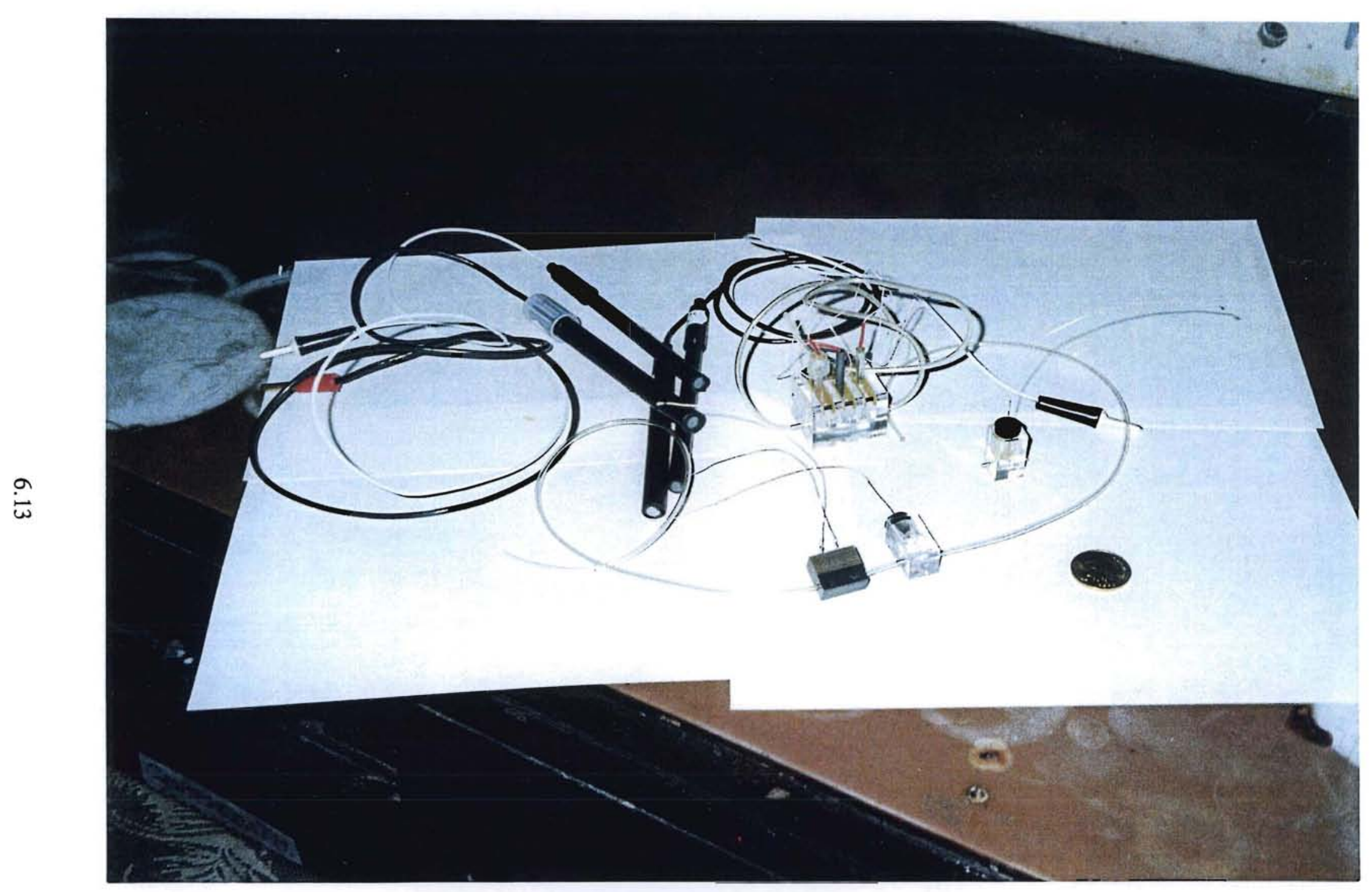

Figure 6.5. Ion-Selective Electrodes Produced by Dr. Yurii Ermolenko in the Laboratory of Ion-Selective Electrodes, Radiochemistry Department, St. Petersburg State University 

Dr. Ermolenko has a wide range of contacts in both Russia and the West. One project in which he is involved is trying to broadcast a television series that will explain to the public where the environmental problems are in Russia and what can be done about them. For example, a recent study found that 85 to $90 \%$ of the air pollution in St. Petersburg results from the automotive exhaust of aged and poorly operating vehicles. However, the "greenies" are spreading the word that the pollution is coming from industry and power generation. He hopes to get the public, environmental and scientific groups, and commercial concerns working together through this program.

\title{
6.3.4 Assessment
}

The members of the Radiochemistry Department were some of the most enthusiastic scientists that I met. Despite the fact that they were not presently being paid, they continue to conduct research and maintain their laboratories. During my brief visit, I saw technology that was directly applicable to several of the Hanford needs, as stated in the recent report on that topic. In particular, the achievements of the Laboratory of Ion-Selective Electrodes were impressive. The enthusiasm of the scientists in the Radiochemistry Department has spilled over to the public sector, as evidenced by the scientists' desire to educate the public about the true nature of pollutants and contamination created by the chemical and nuclear industries.

\subsubsection{Possible Collaborations}

\author{
XPS of Uranium and Technetium Compounds \\ Russians: Dr. Yurii F. Batryakov \\ Americans: Molecular Sciences Research Center at PNL \\ (Material Sciences Department) \\ Other PNL Staff \\ Ion-selective Electrodes \\ Russians: Dr. Yurii E. Ermolenko \\ Americans: Molecular Sciences Research Center at PNL \\ (Art Janata) \\ Westinghouse Hanford Corporation \\ (tank monitoring)
}

\subsection{Khlopin Radium Institute}

\subsubsection{General Description}

The Khlopin Radium Institute is well known to DOE and PNL. This institute is one of the Minatom institutes and was responsible for developing the Soviet nuclear program. At present, the institute is involved, among other projects, with the processes (chlorinated cobalt dicarbollide) that will be used at a new reprocessing plant being constructed in Krasnoyarsk-26. I had visited this institute in July as a guest of Valerii Romanovskii and made a return visit on this trip as the guest of Dr. Dmitri N. Suglobov, a well known researcher whose interests touch on technetium chemistry. 


\subsubsection{Dr. Dmitri N. Suglobov}

Dr. Suglobov has been conducting research at the Khlopin Radium Institute for many years. He works mostly with the chemistry and spectroscopy of actinide complexes, volatile actinide and lanthanide complexes, and technetium chemistry. Among some of his more important discoveries are a volatile lanthanide complex that can produce a vapor pressure of one atmosphere and a method for coating technetium onto ships to prevent growth of barnacles. In addition, researchers at Khlopin have been involved in the nuclear fuel cycle and plutonium production since its beginning. They are now addressing environmental issues as well.

Dr. Suglobov described his work to me in detail, and I spent several minutes telling him about my technetium research. We then discussed the IEI and the possibilities at Khlopin. Dr. Suglobov mentioned that things have changed dramatically at Khlopin in the last few years; the Institute is now very open. He felt there would be no problem establishing an IEI office in Khlopin.

Dr. Suglobov was very interested in seeing the Memorandum of Understanding that was signed in Novosibirsk. I told him that I would fax him a copy either from Moscow or Richland. Dr. Suglobov said that he would then take the copy to the laboratory director and discuss it with him. He was very positive about the outcome.

\subsubsection{Assessment}

The Khlopin Radium Institute has recently split from its former funding source and is now charting its own course; thus, the institute is very interested in contract research with the West. The members of the institute have very aggressively been pursuing research in reprocessing spent nuclear fuel and in nuclear medicine. On my July trip, I toured the facilities that are used to produce ${ }^{99} \mathrm{Mo}$ for use in the St. Petersburg area. These facilities are equal to those used at PNL for producing ${ }^{90} \mathrm{Y}$, in other words, their facilities are typical of Western standards. The existing contract with EM-50 of DOE is further evidence of the confidence placed on the personnel of this institute by American funding sources.

Dr. Suglobov was very enthusiastic about the possibility of opening an office of the IEI at Khlopin. In fact, he has already responded (10/21/93) that Professor A. I. Karelin, the Director of Khlopin, is ready to discuss organizing an ecological laboratory of the IEI at Khlopin.

\subsubsection{Possible Collaborations}

Actinide and Technetium Chemistry

Russians: Dr. Dmitri N. Suglobov

Americans: Several centers at PNL

Westinghouse Hanford Corporation 


\section{Radiochemical Processing and Environmental Problems}

Russians:

Americans: Several centers at PNL

Westinghouse Hanford Corporation

\subsection{Alga Fund}

\subsubsection{General Description}

Alga Fund is a newly formed (by Professor Valerii A. Isidorov of the St. Petersburg State University Chemistry Department) private company that publishes journals and books. One of their recent additions is the Journal of Ecological Chemistry, which is published in Russian and English.

\subsubsection{Dr. Valerii A. Isidorov}

Dr. Isidorov presented me with copies of the first four issues in Russian and the first issue in English of the Journal of Ecological Chemistry. On an international level, the journal addresses chemical questions related to the ecology. Dr. Isidorov mentioned that he would like to have the English edition of his journal published in the West. This may be an issue that the IEI can resolve.

Dr. Isidorov was quite interested in ecological questions, especially those concerning hydrocarbons and halogenated hydrocarbons in the atmosphere. He gave me a copy of his book Organic Chemistry of the Atmosphere. The second edition of the book has recently appeared. In addition, Dr. Isidorov has written another book that has been translated into English, Volatile Emissions of Plants: Composition, Emission Rate, and Ecological Significance. Dr. Isidorov is looking for a publisher for this book since he was unhappy with Springer-Verlag's turn-around time. He provided me with a copy of the advertisement for the book.

In addition to his publishing activities, Dr. Isidorov seems to be the stimulus for organizing scientists from various fields into a society concerned about the ecology. He has contacts in St. Petersburg that are drawn from the ranks of the departments of chemistry, physics, and radiochemistry, for example, at St. Petersburg State University. In addition, several environmentally related groups are forming institutes in St. Petersburg to address air and water pollution.

I probed Dr. Isidorov about the interest in environmental problems at Novosibirsk. His reply was that the interest there is very limited, mostly directed toward very narrow local questions. He mentioned that Academician Koptyug expresses interest, but that little environmental work of substance is accomplished at Novosibirsk. He feels that Novosibirsk is too distant, has poor communications, and is directed toward the natural resources of Siberia. He was somewhat more approving of Moscow's interest in the environment, although he was concerned that Moscow has historically focused on the theoretical side of problems rather than on the implementation of solutions. Dr. Isidorov feels that St. Petersburg is at the center of environmental activities in Russia. Although his laboratory rarely 
employs radioactive compounds, he was well aware of the presence of the Khlopin Radium Institute and suggested that it would be a perfect place for an office of the IEI. He would very much like to work with such an office should it be established. He feels that the Journal of Ecological Chemistry could serve as a vehicle for disseminating information whereas the new institutes, the society, or Khlopin Radium Institute could serve as the partner.

\subsubsection{Assessment}

Dr. Isidorov obviously is a very energetic and successful businessman. He is fairly familiar with Western business practices owing to his involvement with publishing books and journals in English. In addition, he has developed numerous contacts with scientists interested in environmental problems in his capacity as editor of the Journal of Ecological Chemistry.

\subsubsection{Possible Collaborations}

Environmental Monitoring, Volatile Organic Carbon (VOC), Publishing Books and Journals, Ecological Society

Russians: Dr. Valerii A. Isidorov

Americans: Volatile Organic Carbon-Integrated Demonstration (VOC-ID) at PNL (Joan Keller, Ben Johnson)

International Environmental Institute

Battelle Press 


\subsection{Moscow}

\subsection{Institute of Physical Chemistry}

\subsubsection{General Description}

The Institute of Physical Chemistry (IPC) is involved in all the focus areas listed in the Hanford needs. In fact, about 60 to $70 \%$ of the processes and procedures used at Chelyabinsk, Tomsk, and Krasnoyarsk was developed at the IPC. Only recently have the other institutes become interested in waste issues, whereas the IPC has been struggling with them since the start of processing. For example, there are many problems with the dicarbollide process developed by Khlopin Radium Institute that probably make it unacceptable to the west. These problems were not recognized earlier when the process was designed.

\subsubsection{Dr. Vladimir M. Gelis}

Dr. Gelis, Head of the Laboratory at IPC was briefed about the goals of the IEI in Russia. He mentioned that his institute submitted a proposal to Science Applications International Corporation (SAIC) for work regarding the Hanford tanks. He thought that this proposal would be funded by WHC; however, WHC has not responded. The grantees were to be notified on September 1. He asked me if I knew anything about this. He was very interested in the idea of an office of the IEI but wanted to know what was in it for his institute and what would be required for its operation so that he could go to the directors and make a case for opening the office in his institute. I replied that the goals of the IEI are to facilitate technology transfer both from Russia to the U.S. and vice versa, to exchange personnel, to organize seminars and conferences on topics of common interest, and possibly to establish and fund joint research projects. He immediately called his colleagues and arranged a tour for a later date.

We toured the facility in the institute that is used to treat the radioactive wastes generated during experiments. The facility consisted of several large holding tanks similar to those used in the West, for example, in the chemistry building at Argonne National Laboratory. These facilities are illustrated in Figure 7.1, which shows a portion of the whole system. There were also filters and ion-exchange columns to remove strontium, cesium, and rare earths, and several experimental columns for producing high-purity scandium. These columns are shown in Figure 7.2. Just before we parted for the day, he mentioned that he is now a consultant for SAIC and has his own car.

Dr. Gelis is well known for his work on ion exchange systems. His laboratory is actively studying ferrocyanides that remove cesium from acidic solution and exchangers for strontium and cesium from neutral solutions. They have a test column in place at one of the production sites.

\subsubsection{Dr. Vyacheslav I. Kareta}

Dr. Kareta heads the laboratory in which issues similar to those related to the Hanford tanks are addressed. For example, they have groups working on tank remediation with respect to isotope separation, solidification, vitrification, and ion exchange. Dr. Kareta suggested that a joint venture is not the 
. 


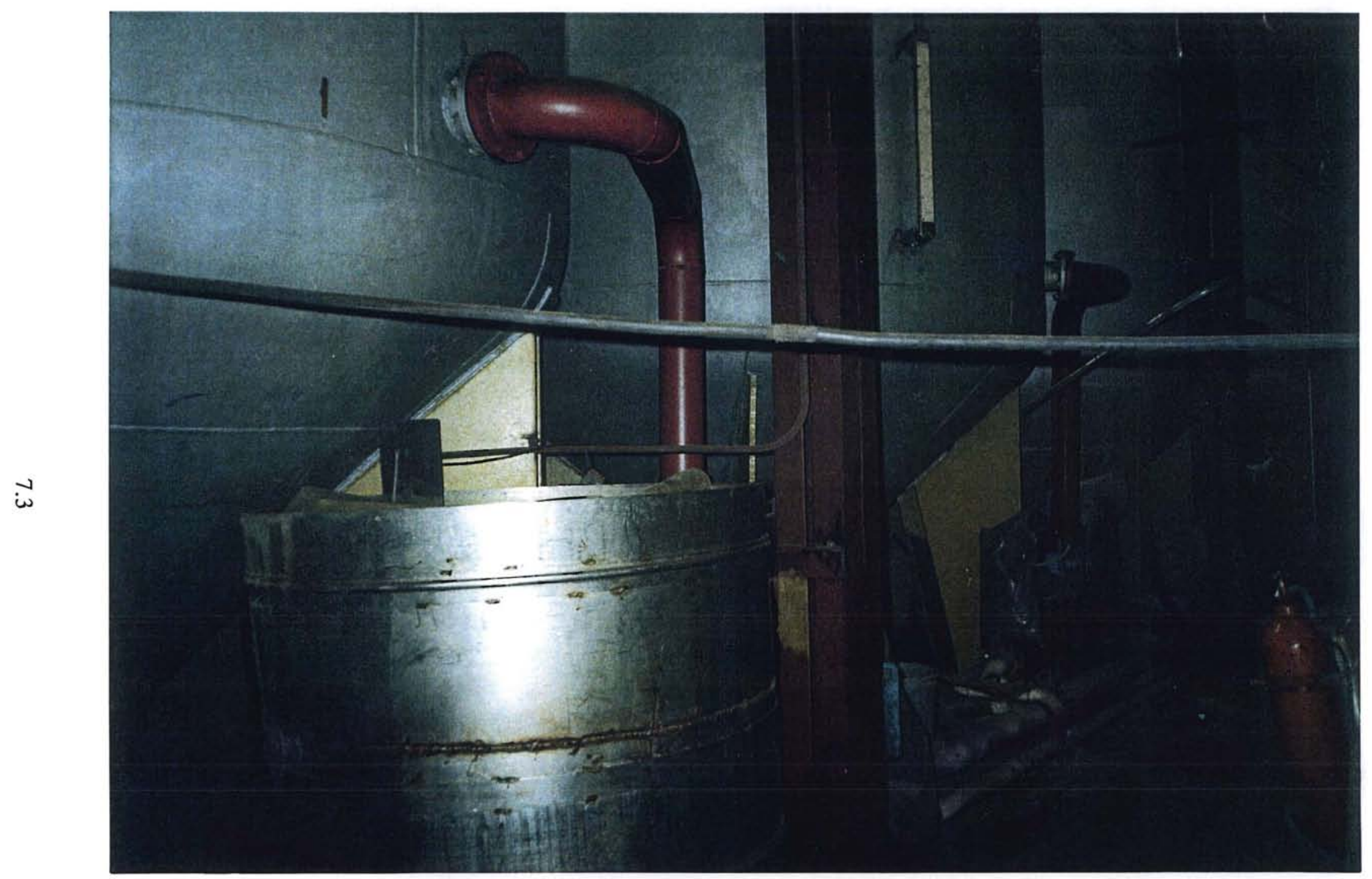

Figure 7.1. A Portion of the Waste Treatment Facility in the Basement of the Institute of Physical Chemistry, Moscow, Russia 


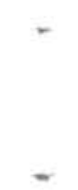

$-$ 


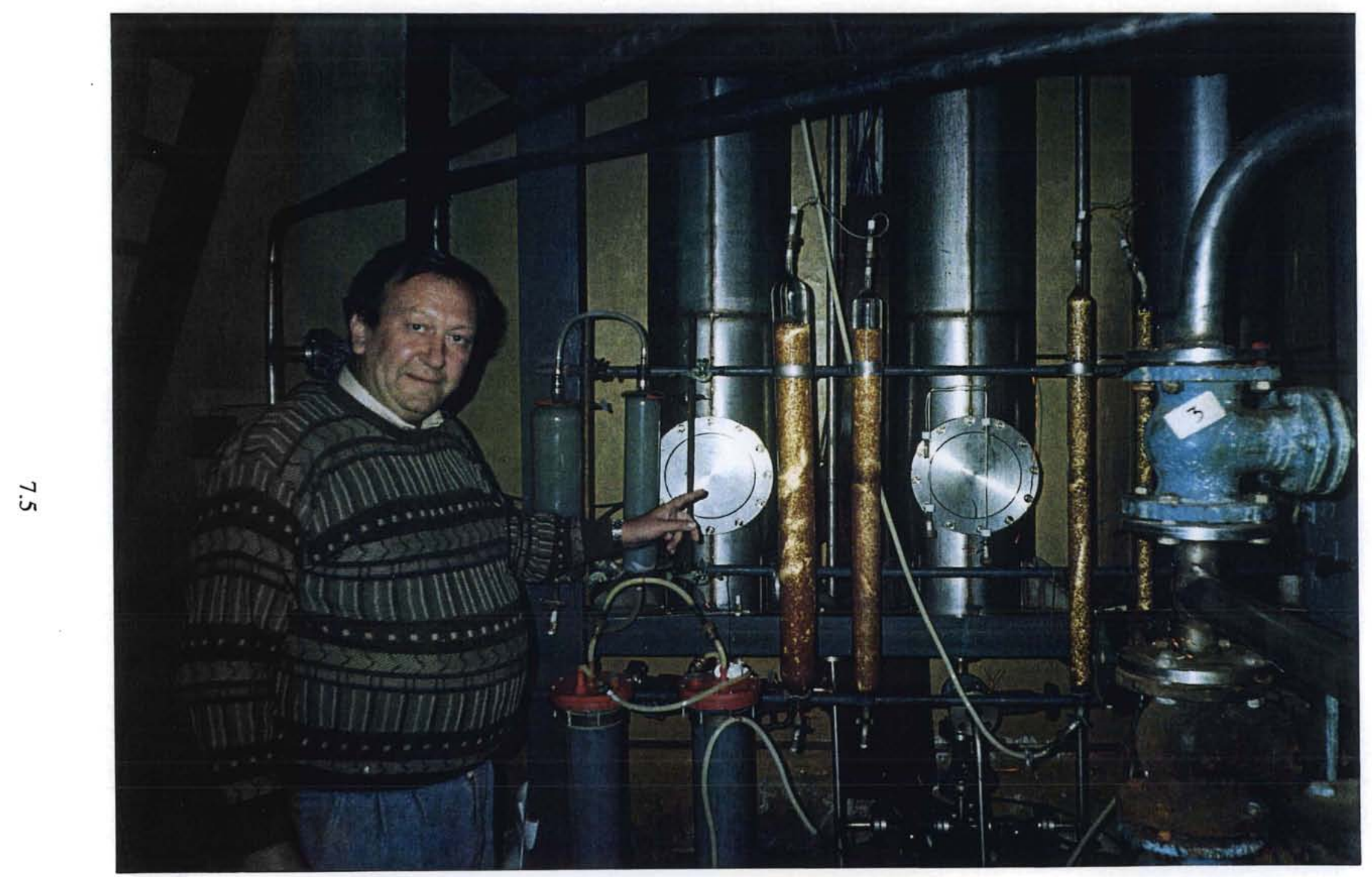

Figure 7.2. Dr. Vladimir Gelis and Columns for Producing High-Purity Scandium at the Institute of Physical Chemistry, Moscow, Russia 


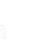

. 
desired method of interaction at present since the government would take an $80 \%$ tax on the operation (I did not determine if this is a tax on the profits). He thought that a joint laboratory in the institute was a good idea. Perhaps we could send two or three Americans to work in the laboratory on problems related to Hanford. He did not think that there would be room for an office in his building.

Dr. Kareta also heads the laboratory that developed a unique filter which looks like a metal spring. A small pilot system using this spring to clarify a cloudy solution is shown in Figure 7.3. The distance between the turns of the spring is of the order of microns to filter small particles out of solution. Dr. Kareta reports the system would work very well to clarify waste streams. His group also developed a continuous flow system for producing $\mathrm{PuO}_{2}$. The system works by collecting a precipitate of $\mathrm{Pu}$ oxalate and firing the oxalate to produce the dioxide. This invention enabled them to considerably increase the production rate of $\mathrm{PuO}_{2}$.

\subsubsection{Dr. Elena V. Zakharova}

Dr. Zakharova has been working with the people at Krasnoyarsk for many years to treat the wastes stored in the ground and in the tanks. They are building new stainless steel tanks for the remediated wastes, the tanks are about the same size as some of those at Hanford. The main concern is to remove the alpha-emitters from the wastes before the wastes are put into the tanks.

\subsubsection{Mr. Yurii S. Pavlov}

Mr. Pavlov is the head of the laboratory of radiation techniques. Among his instruments are four linear accelerators with attached spectrophotometric instrumentation and at least two ${ }^{60} \mathrm{Co}$ irradiation chambers that can reach dose rates of up to $8 \cdot 10^{6} \mathrm{rad} / \mathrm{h}$. The equipment is presently idle except for one of the linear accelerators that is used to sterilize medical syringes. This linear accelerator is shown in Figure 7.4. The beam from the accelerator is rapidly oscillated to irradiate boxes of syringes.

\subsubsection{Assessment}

Dr. Gelis feels that Moscow in general and the IPC in particular would be the right place for the IEI to concentrate their efforts. The IPC has long been involved in fuel processing. They have dealt with the waste issue for many years. There are eight institutes of Minatom in Moscow (and Minatom itself), only one in St. Petersburg (Khlopin), and none in Novosibirsk. In addition, communications and connections are very convenient in Moscow. For example, St. Petersburg is only several hours by train. The problems with communication and connections in Novosibirsk would, in his opinion, be very serious.

Much of the technology that has been developed at the IPC would be of interest at Hanford. Considering the short length of the IPC tour, one can only speculate about other technologies that may have been developed there. However, as with so many of the institutes in Russia, there is little operating capital and much of the IPC is idle. 


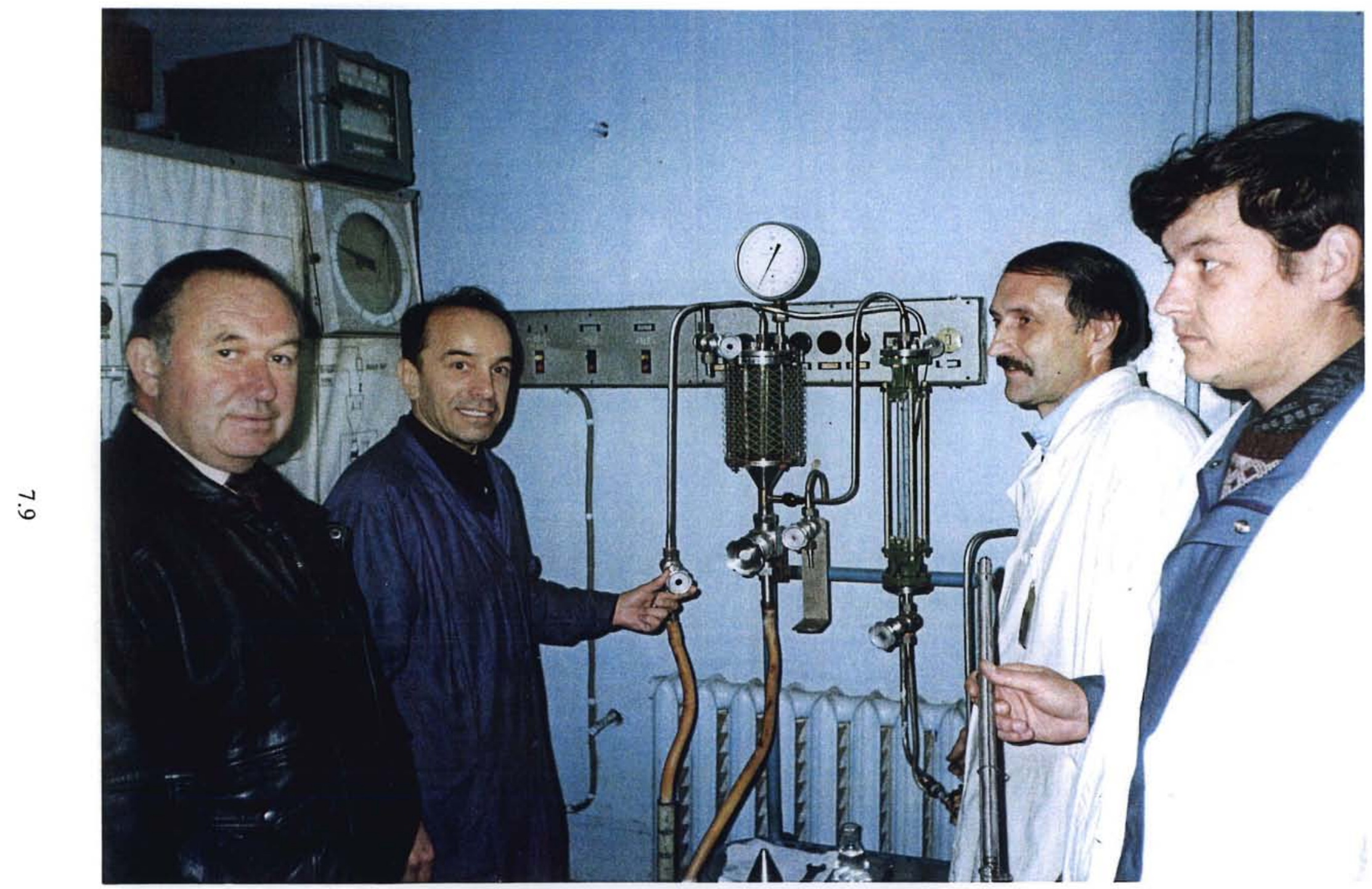

Figure 7.3. Dr. Vyacheslav Kareta and Coworkers Demonstrating the Operation of Their System for Clarifying Solutions at the Institute of Physical Chemistry, Moscow, Russia 



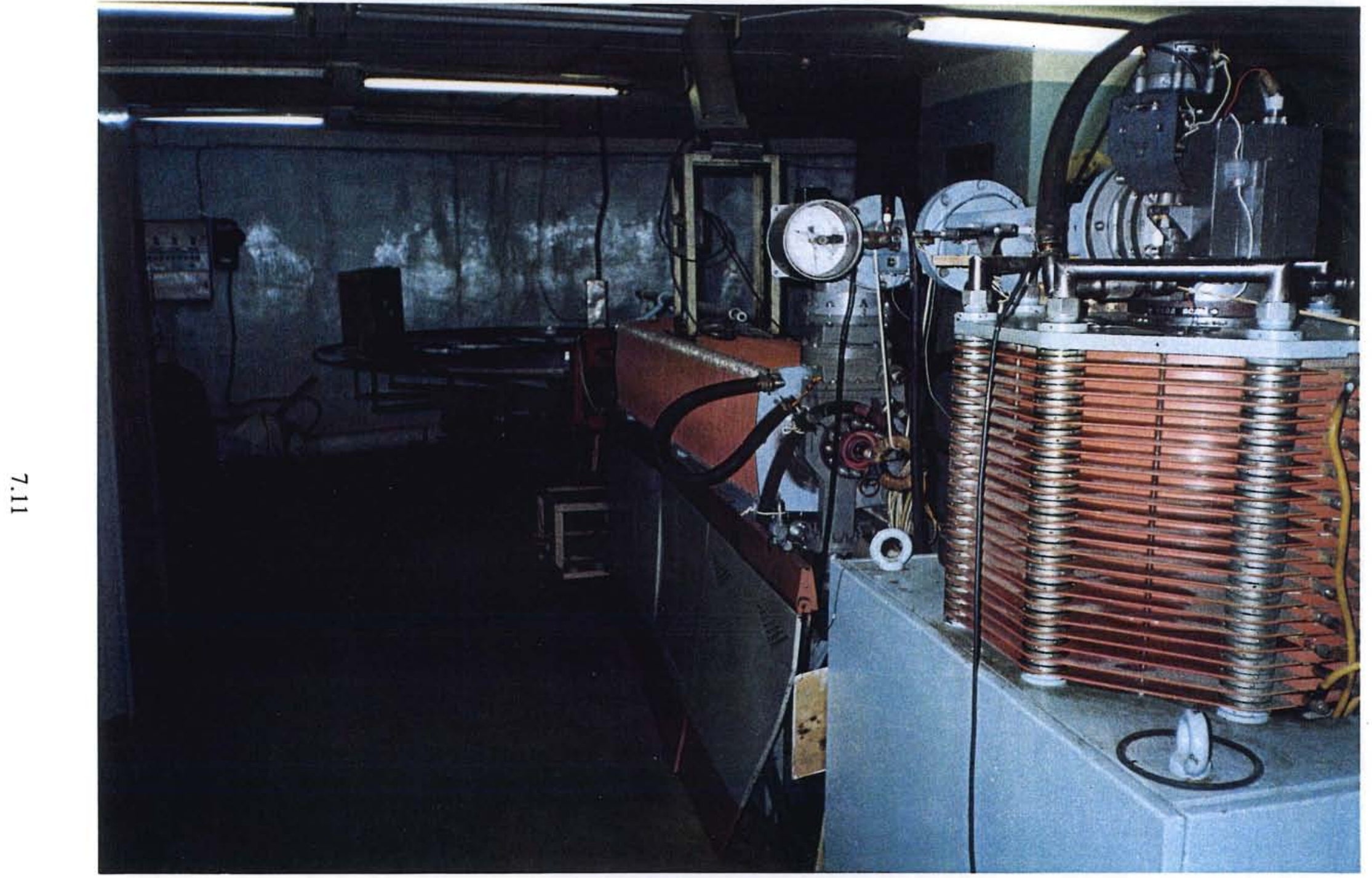

Figure 7.4. Linear Accelerator Used to Irradiate and Sterilize Medical Equipment at the Institute of Physical Chemistry, Moscow, Russia 


\title{
7.1.7 Possible Collaborations
}

\author{
Ion-exchange Systems for Actinides, $\mathrm{Cs}$, and $\mathrm{Sr}$ \\ Russians: Dr. Vladimir M. Gelis \\ Americans: EM-50 \\ Material and Chemical Sciences Center at PNL \\ Molecular Sciences Research Center at PNL
}

\section{System for Clarifying Cloudy Solutions}

Russians: Dr. Vyacheslav I. Kareta

Americans: Tank Waste Remediation System at PNL

\section{Tank Waste Treatment}

Russians: $\quad$ Dr. Elena V. Zakharova

Americans: Tank Waste Remediation System at PNL

Sterilization of Medical Equipment, Linear Accelerators

Russians: Dr. Yurii S. Pavlov

Americans: Tri-City Industrial Development Council

Molecular Sciences Research Center at PNL

\subsection{All-Russian Scientific-Research Institute of Chemical Technology}

\subsubsection{General Description}

The All-Russian Scientific-Research Institute of Chemical Technology is one of the Minatom institutes and is directed by Academician Skorovarov. Its main goals involve processing mined uranium into fuel pellets. Unlike Western processing, the uranium is processed into $\mathrm{UF}_{6}$ at the mine. This avoids the environmentally dirty production of $\mathrm{UF}_{4}$ and the shipping of yellow cake. The institute also produces $F_{2}, H F$, and equipment to work with these materials.

The institute consists of eight divisions, of which the Chemical Conversion Division is one. The Chemical Conversion Division has six laboratories and about 200 people. It is directed by Dr. Evgenii A. Filippov. The institute has buildings for production of $\mathrm{F}_{2}$ and $\mathrm{UF}_{6}$ in addition to hot cells for plutonium work. These hot cells are presently without a mission.

After uranium, the most important metal processed by the institute is gold. In addition, several other metals are processed (e.g., $\mathrm{Co}, \mathrm{Ni}, \mathrm{Cu}$ ). The institute led the reconstruction of the plants at Tomsk, Krasnoyarsk, and Chelyabinsk. The equipment designed for reprocessing fuel rods consists of "krab," a radiochemically safe cell, and a centrifugal extractor fabricated completely of fluoroplastic.

Dr. Filippov was very open about a new process that the institute developed to separate metal ions using electrodiffusion through horizontal liquid membranes. The apparatus has only been developed on a laboratory scale and needs additional funding for further development. The apparatus consists of a 
liquid membrane covering an aqueous solution of ions. The membrane extends below a barrier separating the cathodic and anodic compartments in addition to forming a continuous layer over it. The ions migrate through the membrane and cross the barrier. Dr. Filippov said that this was his division's newest result.

\subsubsection{Mr. Aleksandr V. Ivanov}

Candidate Ivanov is the head of the laboratory that uses plasma melting to refine metals and wastes. The laboratory has developed a method for treating liquid wastes in a plasma vessel that produces a solid suitable for vitrification. The process is shown in Figure 7.5 as a dynamic electrically lighted display. The gaseous products include $\mathrm{NO}_{\mathrm{x}}$, which is converted to nitric acid and reused. In addition, gaseous mixtures can be treated in the equipment. For example, $\mathrm{UF}_{6}$ can be destroyed to produce yellow cake and HF, which is then reused.

\subsubsection{Dr. Vitali T. Gotovchikov}

Dr. Gotovchikov, Chief of the Laboratory, works with induction furnaces to refine metals. The furnaces melt metals by induction heating and produce slags of impurities on the surface of the fused metal. The method has recently been used to produce ultrapure scandium as part of a conversion program. The method can also be used to treat high-level waste (HLW) (including organic and metallic sludge, metallic containers, soils, salt cakes, and combustibles) to produce oxides suitable for vitrification. The method has been used since 1979 to produce fuel rods $\left(\mathrm{UO}_{\mathrm{x}}\right.$ and MOX). The method is also useful for producing metals that are insoluble in the plasma and for extracting radioactive elements into the slag.

\subsubsection{Dr. Anna K. Nardova}

Dr. Nardova is the chief of a laboratory that has developed a method for producing monodispersed microspheres of metal oxides. I understand that the method works on the principle of countercurrent flow of nebulized droplets through a sol-gel medium. A working-scale model is shown in Figure 7.6. A pilot-scale model is operational. In addition, Dr. Nardova's laboratory has developed a method and apparatus for solidifying radioactive wastes by high-temperature adsorption of the metals on inorganic matrices. A working-scale model of the equipment was viewed and is shown in Figure 7.7. An operating model is capable of handling all the wastes produced at Tomsk. Dr. Nardova also works closely with Drs. Dzekun and Drozhko of Chelyabinsk.

\subsubsection{Dr. Vyacheslav M. Abashkin}

Dr. Abashkin is a Senior Research Chemist in the division. He has worked with Dr. Nardova to develop a process using only crown ethers to remove cesium and strontium from wastes. The process is virtually a "PUREX" process for cesium and strontium. A process for extracting technetium, and organics was also developed. Drs. Abashkin and Filippov mentioned that there are several problems with the dicarbollide process, particularly, with the solvent, that their process avoids. They were 


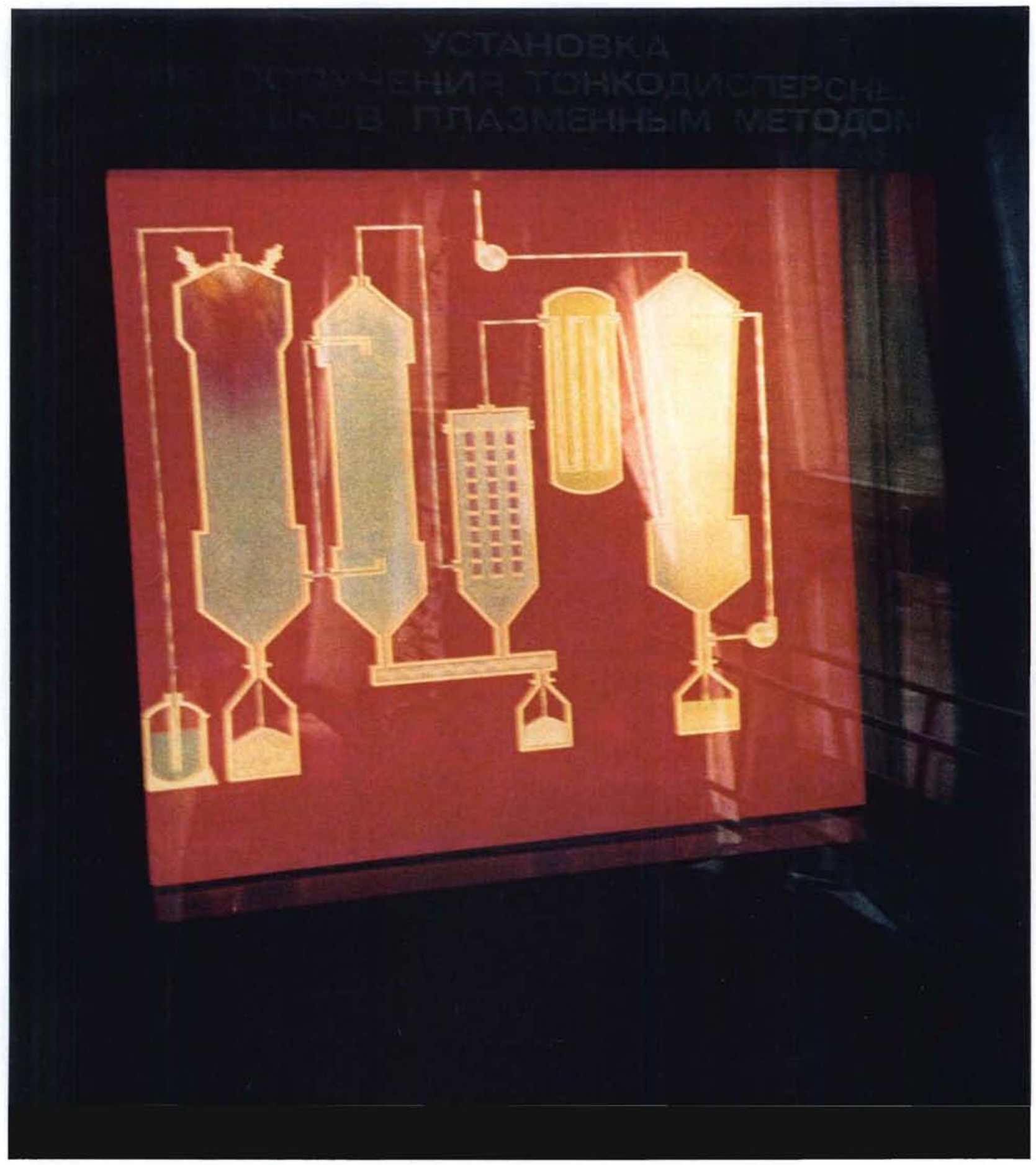

Figure 7.5. Display Diagram of the Plasma Process for Converting Liquid Wastes to Fine Powder at the Institute of Chemical Technology, Moscow, Russia 


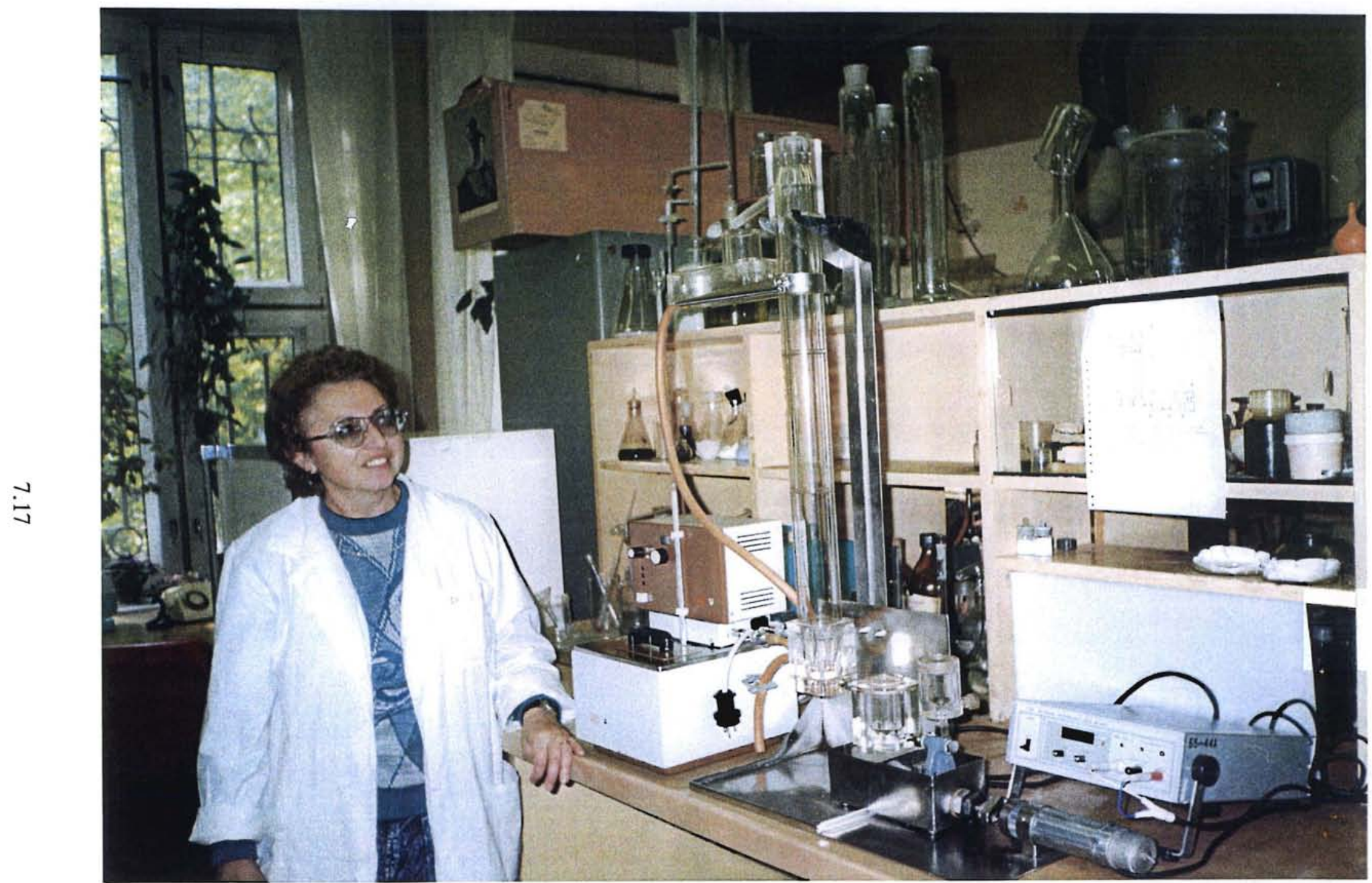

Figure 7.6. Scale Model of Apparatus for Producing Microspheres of Metal Oxides at the Institute of Chemical Technology, Moscow, Russia

. 



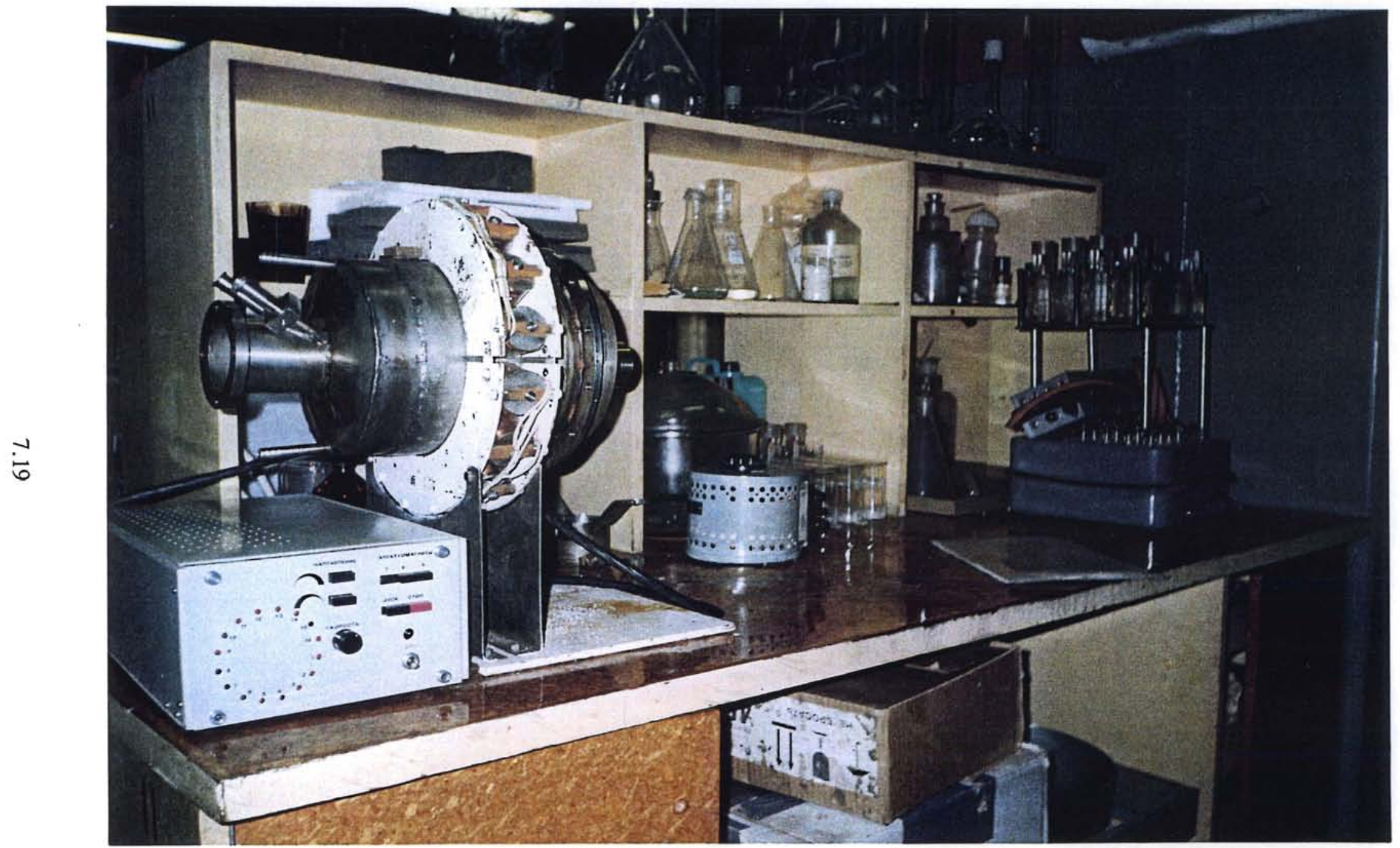

Figure 7.7. Scale Model of Apparatus for Solidifying Radioactive Wastes at the Institute of Chemical Technology, Moscow, Russia 
also confident that they could remove rare earths using crown ethers. Dr. Abashkin has also developed a process for producing thin films of metal oxides by liquid deposition. This enables thin films to be prepared on objects of irregular shape. The oxides include insulators, ferroelectrics, high-temperature superconductors, and fuel-cell coatings.

\subsubsection{Assessment}

The Chemical Conversion Division of the Institute of Chemical Technology has developed several technologies that could be of great interest to Hanford. The institute seems to be operating and producing results to a greater extent than most other institutes in the former Soviet Union. The staff are very knowledgeable about the problems of storing and treating radioactive wastes.

\subsubsection{Possible Collaborations}

Plasma Refinement and Solidification, $\mathrm{NO}_{\mathbf{x}}$ Conversion

Russians: $\quad$ Mr. Aleksandr V. Ivanov

Americans: Destruction of $\mathrm{NO}_{\mathrm{x}}$ at Vitrification Plant

Tank Waste Remediation System at PNL

Induction Heating of Oxides and Metals

Russians: Dr. Vitali T. Gotovchikov

Americans: Fast Flux Test Facility

Isaiah Project

(fuel production)

Hanford Waste Vitrification Plant

Tank Waste Remediation System at PNL

(waste solidification)

Monodisperse Metal-oxide Microspheres

Russians: Dr. Anna K. Nardova

Americans: Molecular Science Research Center at PNL

(Chuck Peden)

Crown Ether Chemistry

Russians: Dr. Vyacheslav M. Abashkin

Americans: Materials and Chemical Sciences Center at PNL

(John Swanson)

Efficient Separations and Processing

Integrated Program at PNL 


\title{
7.3 Institute of Organoelement Compounds
}

\subsubsection{Dr. Yurii A. Borisov}

Dr. Borisov heads the Laboratory of Quantum Chemistry in the A. N. Nesmeyanov Institute of Organoelement Compounds (IOEC) and is a former student of Zinfer Ismagilov. He is well connected at the RAS. We discussed the abilities of the institutes in Moscow to satisfy some of the Hanford needs. Dr. Borisov also gave me a completed SABIT application and has since been sponsored by Dr. Bruce Garrett of the MSRC.

\subsubsection{Dr. Yurii S. Nekrasov}

Dr. Nekrasov, Head of the Laboratory of the Mechanisms of Chemical Reactions at the A. N. Nesmeyanov IOEC, and two of his colleagues discussed the capabilities of the IOEC. Dr. Nekrasov heads a laboratory in which sorbents for benzene are studied. The sorbents are prepared in small batches and tested at oil refineries. The laboratory is also studying magnetic particles that can absorb cesium and strontium, among other metals. These particles were developed to treat the water and soil contaminated by the Chernobyl accident. The particles are placed in the solution containing cesium and strontium and are then separated by magnetic means after they are saturated. In addition, Dr. Nekrasov's laboratory is involved in studies designed to remove heavy metals from organisms and to purify blood of harmful substances.

\subsubsection{Assessment}

The visit to this institute was very brief. There were some areas of investigation that are similar to areas in which DOE is interested.

\subsubsection{Possible Collaborations}

\section{Computational Chemistry}

Russians: Dr. Yurii A. Borisov

Americans: Molecular Sciences Research Center at PNL

(Bruce Garrett, Bruce Bunker)

\author{
Sorbents for Organics, Magnetic Separations \\ Russians: Dr. Yurii S. Nekrasov \\ Americans: Efficient Separations and Processing Integrated Program at PNL \\ Tank Waste Remediation System at PNL \\ Savannah River Laboratory \\ (benzene sorbents) \\ Argonne National Laboratory \\ (Luis Nunez, magnetic separations)
}




\subsection{Institute of Organic Chemistry}

\subsubsection{Dr. Eugene S. Mortikov}

Dr. Mortikov, Head of the Laboratory, N. D. Zelinskii Institute Organic Chemistry, Moscow, is working to develop technology for producing hydrocarbon and chlorocarbon compounds that do not result in wastes. They accomplish this by using catalysts, in particular, zeolites. Dr. Mortikov mentioned that ion-exchange resins are produced at many sites in Russia. His laboratory is working on the synthesis of vinylpyridine that is used at Yaroslavl to make resins for extracting uranium in Dr. Laskorin's laboratory at the Institute of Physical Chemistry in Moscow. The catalyst technology that Dr. Mortikov has developed is highly selective. There are several catalysts that he believes are only available in Russia.

\subsubsection{Assessment}

The work of the institute in general could not be evaluated. Dr. Mortikov seems to have valuable knowledge about the chemical industry in Russia.

\subsubsection{Possible Collaborations}

\section{Zeolite Catalysts}

Russians: Dr. Eugene S. Mortikov

Americans: West Valley

Lane Bray at PNL

\subsection{Ministry of Foreign Affairs}

\subsubsection{Directorate of International Scientific and Technological Cooperation}

I visited Mikhail E. Kokeev, Deputy Director of the Directorate of International Scientific and Technological Cooperation, Ministry of Foreign Affairs of the Russian Federation, and Nikita N. Sikachev, his assistant who recently spent several months at PNL on the SABIT program. Kokeev was very receptive to the idea of the IEI opening an office in Russia. He was very positive about the speed with which an office could be opened in Novosibirsk. He felt that it would take longer to open an office in Moscow or St. Petersburg, especially if it were a joint venture. He was also very complimentary of Academician Koptyug in Novosibirsk and expressed regret that Koptyug did not sign the Memorandum of Understanding. Kokeev said that he would have called Koptyug and asked him to sign the memorandum if he had known about it.

Kokeev remarked that a new university recently opened in Moscow. He read about it in a paper called "Green World," to which he suggested I subscribe. The new university is the International Ecological Independent University. Kokeev thought this would be a good partner for the IEI. The 
university is supported by the Ministry for Conservation of Nature and the Environment. He gave me the phone numbers of two members of this ministry that he thought could be of help. In addition, Kokeev requested information about the IEI's goals and areas of interest. This material can be mailed to him at the Russian Mission of the UN in New York. Sikachev asked that his regards be given to the people that he worked with at PNL during his SABIT internship. He also said that he would call Ismagilov and ask him about the IEI office.

Kokeev presented me with a copy of a "white paper" recently published by the Administration of the President of the Russian Federation. The paper is entitled, "Facts and Problems Related to the Burial of Radioactive Wastes in Seas Adjoining the Russian Federation."

\subsubsection{Assessment}

Mikhail Kokeev has very good contacts throughout Russia owing to his position in the Ministry of Foreign Affairs. He offered sound advice about the difficulties that might be encountered in opening an IEI office in the former Soviet Union.

\subsubsection{Possible Collaborations}

International Scientific and Technological Collaboration

Russians: Mikhail E. Kokeev

Americans: International Environmental Institute 
Appendix A

People Contacted 



\section{Appendix A}

\section{People Contacted}

\section{A.1 Novosibirsk}

\section{A.1.1 Institute of Catalysis}

Sergei Rifovich Khairulin, Junior Researcher Mikhail Anatol'evich Kerzhentsev, Research Associate Dmitrii Aleksandrovich Arendarskii, Scientist Natal'ya Anatol'evna Koryabkina, Junior Researcher Andrei Valer'evich Simakov, Researcher Aleksandr Anatol'evich Kirchanov, Researcher Vladimir Borisovich Fenelonov, Inst. Cat.

Boris Maksimovich Anikeev, Scientific Production Center "Altai," Director of the Joint-Stock companies called TECHNOLOG and BIOM Academician Kirill Il'ich Zamaraev, Director

\section{A.1.2 Institute of Mathematics}

Alexander Mikhailovich Blokhin, Chairman of the Department of Differential Equations

\section{A.1.3 Institute of Geology and Geophysics}

Vitalii Nikolaevich Dorovskii

Aleksei Emil'evich Kontorovich, Deputy Director

Fyodor Vasil'evich Sukhorukov, Head of Laboratory

\section{A.1.4 Institute of Inorganic Chemistry}

Yurii Gennad'evich Stenin, Deputy Director

Fedor Andreevich Kuznetsov, Director

Vladimir Vladimirovich Volkov, Inst. Inorg. Chem.

Vladimir L'vovich Bogatyrev, Head of the Laboratory

Igor' Konstantinovich Igumenov, Chief of the Laboratory for Halide Compounds of the Noble Metals

Lev Nikolaevich Mazalov, Deputy Director

Valentin Aleksandrovich Titov, Head of the Laboratory

Yan Vladimirovich Vasil'ev, Leading Research Worker

Anatolii Alekseevich Pavlyuk, Senior Researcher

Vladislav Germanovich Torgov, Head of the Laboratory 


\section{A.1.5 Siberian Division, Russian Academy of Sciences}

Yurii Ivanovich Shokin, Gen. Sci. Sec.

\section{A.1.6 Institute of Thermal Physics}

Sergei Vsevolodovich Stankus

\section{A.1.7 Siberian Branch All-Russian Scientific-Research Planning Institute of Energy Technology}

Yurii Vladimirovich Ostrovskii, Head Scientific Associate

Sergei Matveevich Boboedov, Chief Engineer

Boris Ivanovich Lunyushkin, Vice Chief Engineer

\section{A.1.8 Institute of Cytology and Genetics}

Rudol'f Iosifovich Salganik, Deputy Director

Gafur Abdulkhaevich Zainiev, Senior Scientific Associate

\section{A.1.9 Institute of Organic Chemistry}

Dr. Boris Grigorievich Derendyaev, Scientific and Technical Center of Chemical Informatics Prof. Vladislav Mikhailovich Vlasov, Deputy Director Assoc. Prof. Victor M. Tormyshev, (Novosibirsk State Univ.), Research Scientist

\section{A.1.10 INEK Corp. (Siberian Research Power Institute)}

Igor' Trofimovich Ovchinnikov, Chief of High-Voltage Biophysics Laboratory

Sergei Petrovich Shul'zhenko, President

\section{A.2 Ufa}

\section{A.2.1 Novoil Refinery}

Foad Rishatovich Ismagilov, Asst. Director of Reconstruction

Nur Rishatovich Saifullin, Director of Reconstruction

Vladimir Nikitovich Karakuts, General Manager

\section{A.2.2 Aviation Mechanics Institute}

Flyur Rashitovich Ismagilov, Senior Scientific Associate

\section{A.2.3 Bashkir State University}

Florida Khusainovna Kudasheva, Head of the Department of Analytical Chemistry and Technolology 


\section{A.3 Kemerovo}

\section{A.3.1 TOKEM Co.}

Aleksandr Anikeevich Moroz, Engineering Center Chief

\section{A.3.2 Kemerovo State University}

Sergei Mikhailovich Ryabyk, Kemerovo State University

\section{A.3.3 Institute of Coal}

Gennadii Ignat'evich Gritsko, Institute of Coal Aleksandr Borisovich Logov, Vice-Director for Science Oleg Vladimirovich Tailakov, Scientific Secretary Vsevolod Modestovich Stankus, Head of Laboratory of Development Technology

\section{A.4 St. Petersburg}

\section{A.4.1 St. Petersburg State University}

Dr. Aleksei Yurievich Ershov, St. Petersburg State University

Dr. Boris Alekseevich Isidorov, "Alga-Fond," Managing Editor

Dr. Yurii Fedorovich Batryakov, St. Petersburg State University

Dr. Yurii Evgen'evich Ermolenko, Associate Professor

\section{A.4.2 Khlopin Radium Institute}

Dr. Dmitri Nikolaevich Suglobov, Khlopin Radium Institute

\section{A.5 Moscow}

\section{A.5.1 From Ulan Ude, met in Moscow}

Dr. Aleksandr Leonidovich Kovalevskii, Biogeochemist, Geological Institute, Buryat Branch

\section{A.5.2 Institute of Organic Chemistry}

Dr. Eugene S. Mortikov, Head of Laboratory

\section{A.5.3 Plenum Publishing Corp.}

Marina Dubrovskaya, General Manager 


\section{A.5.4 Institute of Organoelement Compounds}

Yurii Andreevich Borisov, Chief of Laboratory of Computer Chemistry, Institute of Organoelement Compounds (Moscow)

Dr. Yurii Stepanovich Nekrasov, Head of Laboratory of the Mechanisms of Chemical Reactions
A.5.5 Institute of Physical Chemistry
Dr. Vladimir Meerovich Gelis, Institute of Physical Chemistry
Dr. Vyacheslav Ivanovich Kareta, Head of Laboratory
Dr. Elena Vasilievna Zakharova, Institute of Physical Chemistry
Dr. Yurii Sergeevich Pavlov, Head of the Laboratory of Radiation Technology

\section{A.5.6 Ministry of Foreign Affairs}

Mikhail E. Kokeev, Deputy Director of the Directorate of International Scientific and Technical Cooperation

Nikita N. Sikichev, Ministry of Foreign Affairs

\section{A.5.7 Institute of Chemical Technology}

Prof. Evgenii Alekseevich Filippov, Manager of Department

Dr. Aleksandr Vasil'evich Ivanov, Head of the Laboratory

Dr. Vitalii Timofeevich Gotovchikov, Head of the Laboratory

Dr. Anna Konstantinovna Nardova, Head of the Laboratory

Dr. Viacheslav Mikhailovich Abashkin, Senior Research Chemist 
Appendix B

Materials Received 


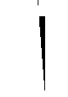




\section{Appendix B}

\section{Materials Received}

The following materials were received during visits to the various institutes and universities. The majority of these materials are in Russian.

A. M. Blokhin, "A study of strong discontinuities stability in continuum mechanics," Sib. J. Diff. Eq., 1(1):3-16 (1992).

A. M. Blokhin, "Symmetrization of continuum mechanics equations," Sib. J. Diff. Eq., 2(1):3-47 (1993).

V. N. Dorovskii, "About an approach to the filtration theory," preprint.

"Kamin Gas Catalytic 'Thermokat’ (TU 483K-A024-01-92), Specifications and Instructions for Use," [in Russian].

"Spherical Alumina. Adsorbent and Support for Catalysts," [in Russian], MNTK (Interministerial Scientific Technological Complex) "Katalizator," Institute of Catalysis, Siberian Division, USSR Academy of Sciences.

"Direct catalytic oxidation of $\mathrm{H}_{2} \mathrm{~S}$ to elemental sulfur," MNTK "Katalizator" Group, Boreskov Institute of Catalysis.

"USSR Academy of Sciences, Siberian Branch, Institute of Inorganic Chemistry."

"International Centre for Materials Research, Siberia," Novosibirsk, April (1992).

"International Center for Material Research (ICMR-S) at Novosibirsk Science Center."

"Asia-Pacific Society for Advanced Materials," APSAM Newsletter, 1, 1992.

"Asia-Pacific Society for Advanced Materials," APSAM Newsletter, 2, 1992.

"Programme of Development of International Research Centres," Siberian Division of the USSR Academy of Sciences.

"APSAM General Assembly and Scientific Conference Program," Sinemorie, August 16-20, 1993, Novosibirsk.

"Novoil New Ufa Oil Refinery" brochure.

"VEU-0.25" Wind-electric apparatus [in Russian].

B. 1 


\section{"Ufimskii Aviation Institute."}

Two photos of the dicarbollides from Volkov's laboratory.

"Polymeric 'host' in clathrate polyhydrates," V. L. Bogatyrev, Yu. A. Dyadin, A. V. Pirozhkov, G. A. Maksakova, G. V. Villeval'd, N. K. Moroz, F. V. Zhurko, S. M. Zemskova, V. I. Skobeleva, S. G. Kozlova, and L. Ya. Sharapova.

"Volatile Compound for Chemical Vapor Deposition New processes of films deposition and data bases of thermal parameters from Siberia."

"X-ray spectral microinvestigation of the chemical states of atoms in $\mathrm{Cd}_{\mathbf{x}} \mathrm{Hg}_{1-\mathrm{x}} \mathrm{Te}-\mathrm{GaAs}$ thin films," V. V. Rezvitskii, B. A. Treiger, I. I. Bondarenko, and L. N. Mazalov.

"The usage of $x$-ray lines form for the identification of the chemical state of silicon atoms in surface layers of silicon wafers," B. A. Treiger, L. N. Mazalov, and E. A. Kravtsova.

"KGW," Optron Technology Ltd. (specifications for KGW crystals).

"Cyclone-Foam Device for Purifying and Cooling Gas," NO VNIPIET.

"Equipment for Recovering Methylchloroform and Methylene Chloride," NO VNIPIET.

"Equipment for Purifying Gases of Nitrogen Oxides by the Ozone Method," NO VNIPIET.

"Catalytic Apparatus KF-1000," NO VNIPIET.

"Thermocatalytic Apparatus Type 'KART'," NO VNIPIET.

"Thermocatalytic Apparatus KART 720, 720B, 3000," NO VNIPIET.

"Thermocatalytic Apparatus Type 'KROT,' 150, 800, 2500," NO VNIPIET.

"Thermocatalytic Apparatus TKM-250," NO VNIPIET.

"Jet Scrubber," NO VNIPIET.

"Ozone-catalytic Equipment OKA-3000," NO VNIPIET.

"Adsorber for Purifying Gases from Harmful Impurities," NO VNIPIET.

"Equipment for Emergency Purification of Air from Chlorine," NO VNIPIET.

"Equipment for Demercurization of Mercury Lamps," NO VNIPIET.

"Technology for High Demercurization of Gases," NO VNIPIET.

"Share-holding Company TOKEM," Product List, Kemerowo. 
"Weekly Information of TOKEM," August 20 and September 1, 1993.

"Not Down, Not Feathers," I. I. Kukushkina and Zh. G. Vasilenko, Kemerovo State University, Kemerovo.

"Siberia and Science," International Exposition, Tsukuba, Japan, 1985.

"Kemerovo State University," Kemerovo, 1979.

"Kemerovo State University," International Relations Division, Kemerovo.

"Informational Packet on Scientific-Technical Achievement No. 92-1499, Catalytic Apparatus with a Recirculating Heat-Exchanger (KROT)," All-Russian Scientific-Research Institute of Interdepartmental Information.

"Informational Packet on Scientific-Technical Achievement No. 91-2053, Catalytic Apparatus with a Regenerating Heat-Exchanger (KART)," All-Russian Scientific-Research Institute of Interdepartmental Information.

"On Selecting Criteria for Thermodynamic Estimation of the Preference for Competing Chemical Reactions," Yu. V. Ostrovskii, A. D. Ryabtsev, and A. I. Novikov, Sib. Fiz.-Tekh. Zh., 6:15-18 (1991).

"Energy Integrals and Their Application to the Study of the Stability of Various Designs," A. M. Blokhin and R. D. Alaev, Novosibirsk Univ. Press, Novosibirsk (1993).

"Forceful Explosions in Magnetic Hydrodynamics," A. M. Blokhin and I. Yu. Druzhinin, Nauka, Novosibirsk (1993).

"Solid-fuel Liquid Nitrogen Generator, A Product of Conversion."

"Possible Applications of the 003s Microscan Analyzer," Scientific Production Association INEK.

Institute of Geology and Geophysics, Siberian Division, Academy of Sciences of the USSR.

Sample Sources, All-Union Association "IZOTOP."

Sources of Alpha- and Neutron-Radiation, All-Union Association "IZOTOP."

Sources of Alpha-, Beta-, Gamma-, and Neutron-Radiation, All-Union Association "IZOTOP."

"Density change of elements on melting," S. V. Stankus, Preprint No. 257, Institute of Thermal Physics, Sib. Div., Russ. Acad. Sci. (1991).

"Density change of elements on melting. Methods and experimental data," S. V. Stankus, Preprint No. 247, Institute of Thermal Physics, Sib. Div., Russ. Acad. Sci. (1991).

"The semiconductor-metal transition in liquid tellurium," V. Ya Prokhorenko, B. I. Sokolovskii, V. A. Alekseev, A. S. Basin, S. V. Stankus, and V. M. Sklyarchuk, Phys. Status Solidi B, 113:453 (1982). 
"Density of Ba and Sr as solids and liquids," S. V. Stankus and P. V. Tyagel'skii, Teplofiz. Kysokikh Temp., 30:725 (1992).

Vestnik Sel'skokhoz. Nauki, No. 2, (1992).

"International Centre for Catalysts Characterization and Testing," Siberian Division, Russ. Acad. Sci.

"Noble metals: Chemistry and analysis. A collection of scientific works," V. G. Torgov and F. A. Kuznetsov (eds.), Inst. Neorg. Khim., Sib. Div., Acad. Sci. USSR, Novosibirsk (1989).

"Noble metals: Chemistry and technology. A collection of scientific works," V. G. Torgov and F. A. Kuznetsov (eds.), Inst. Neorg. Khim., Sib. Div., Acad. Sci. USSR, Novosibirsk (1989).

"Effect of side processes on the completion and selectivity of Se extraction by $\alpha$-olefins from bromide solutions," M. G. Demidova, V. G. Torgov, and S. V. Tkachev, Zh. Neorg. Khim., 46(10):1929 (1991).

"Effect of the nature of added donor on the non-cation-exchange extraction of uranyl sulfate by mixtures of di-2-ethylhexylphosphoric acid and organic oxides," V. G. Torgov, T. V. Us, M. K. Drozdova, and S. V. Tkachev, Izv. Sib. Otd. Akad. Nauk SSSR, Ser. Khim. Nauk, 6:133 (1987).

"On synergic effects during uranyl-sulfate extraction by organophosphorus acids and petroleum sulfoxides," V. G. Torgov and T. V. Us, Izv. Sib. Otd. Akad. Nauk SSSR, Ser. Khim. Nauk, 2:69 (1987).

"Complexation and solvation during extraction of acetic acid by tri-iso-amylphosphine and 2-nonylpyridine oxides," V. G. Torgov, I. V. Nikolaeva, and M. K. Drozdova, Izv. Sib. Otd. Akad. Nauk SSSR, Ser. Khim. Nauk, 1:64 (1987).

"Comparative extraction ability of tri-iso-amylphosphine and 2-nonylpyridine oxides for perchloric acid," V. G. Torgov, I. V. Nikolaeva, M. K. Drozdova, and D. D. Bogdanov, Zh. Neorg. Khim., 35(1): 147 (1990).

"Effect of diluent nature on nitric-acid extraction by heterocyclic $N$-oxides," M. K. Drozdova, V. G. Torgov, Z. A. Larionova, V. N. Andrievskii, and I. V. Nikolaeva, Zh. Neorg. Khim., 30(2):453 (1982).

"Equilibrium during extraction of thorium nitrate by sulfoxides, $\mathrm{N}$-oxides, and organophosphorus compounds," Izv. Sib. Otd. Akad. Nauk SSSR, Ser. Khim. Nauk, 1:81 (1978).

"Brief Description of Project 'HPUT - technique'," Scientific Production Association INEK.

"Mechanochemical methods for synthesizing derivatives of boron hydrides," V. V. Volkov and K. G. Myakishev, Izv. Sib. Otd. Akad. Nauk SSSR, Ser. Khim. Nauk, No. 3, No. 7, 6 (1979).

"Mechanically activated reactions of $\mathrm{Pb}(\mathrm{II})$ halides with tetrahydroborates of alkali metals," K. G. Myakishev and V. V. Volkov, Sib. Khim. Zh., 2:144 (1991). 
"Preparation of borazine by reaction of sodium tetrahydroborate with ammonium chloride after preliminary mechanical activation, " V. V. Volkov, A. A. Pukhov, and K. G. Myakishev, Izv. Sib. Otd. Akad. Nauk SSSR, Ser. Khim. Nauk, 3:116 (1983).

"Comparative study of methods for synthesizing $\mathrm{Zr}$ and $\mathrm{Hf}$ tetrahydroborates," V. V. Volkov and K. G. Myakishev, Izv. Sib. Otd. Akad. Nauk SSSR, Ser. Khim. Nauk, 1:16 (1989).

"Multinuclear $\pi$-complexes of Co(III) containing the (3,6)-1,2-dicarbakanastide anion," V. V. Volkov and S. Ya. Dvurechenskaya, Izv. Akad. Nauk SSSR, Ser Khim., 10:2356 (1981).

"On the existence of the anion $\left[\left(\pi-\mathrm{B}_{9} \mathrm{C}_{2} \mathrm{H}_{11}\right)_{2} \mathrm{Co}_{4}\left(\pi-\mathrm{B}_{8} \mathrm{C}_{2} \mathrm{H}_{10}-\pi\right)_{3}\right]^{4-}$," V. V. Volkov and S. Ya. Dvurechenskaya, Koord. Khim., 8(2):263 (1982).

"Extraction and solvation of alkali metal ions as salts of Co(III) dicarbollide," I. M. Ivanov, V. V. Volkov, and N. K. Kalish, Sib. Khim. Zh., 4:78 (1991).

"On the structure formation of amorphous boron during pyrolysis of higher boranes," V. V. Volkov, G. S. Yur'ev, L. I. Brezhneva, K. G. Myakishev, and L. A. Prokhorov, Izv. Sib. Otd. Akad. Nauk SSSR, Ser. Khim. Nauk, 2:81 (1989).

"Thermal transformations of tetramethylammonium bis[ $\pi$-(3)-1,2-dicarbollyl]cobalt(III)," V. V. Volkov, G. S. Yur'ev, S. G. Vasil'eva, G. S. Voronina, and K. G. Myakishev, Izv. Akad. Nauk SSSR, Ser. Khim., 1500 (1990).

"Raman spectra of Fe(III), Co(III), Ni(IV), and Sn(II) dicarbollides," K. V. Kradenov, S. V. Vasil'eva, V. V. Volkov, and B. A. Kolesov, Izv. Sib. Otd. Akad. Nauk SSSR, Ser. Khim. Nauk, No. 2, 23 (1990).

Biogeochemistry of Plants, Aleksandr Leonidovich Kovalevskii, Nauka, Novosibirsk (1991).

Zhurnal Ekologicheskoi Khimil, Nos. 1 and 2 (1992), Nos. 1 and 2 (1993).

Volatile Emissions of Plants: Composition, Emission Rate, and Ecological Significance, Valerii Alekseevich Isidorov, Alga-Fund Publishing House, St. Petersburg.

Journal of Ecological Chemistry, No. 1 (1992).

Organic Chemistry of the Atmosphere, B. A. Isidorov, Khimiya, St. Petersburg (1992).

"Chemical shifts in X-ray $\mathrm{K} \alpha$-emission spectra of technetium compounds," L. L. Makarov, S. V. Kryutchkov, Y. M. Zaitsev, N. O. Sablina, K. E. German, and A. F. Kuzina, in: Technetium and Rhenium in Chemistry and Nuclear Medicine 3, M. Nicolini, G. Bandoli, and U. Mazzi (eds.), Raven Press, New York.

"Solid-contact electrodes with polyvinylchloride membranes," St. Petersburg University, ScientificTechnical Service Center "Potential" Ionometry Center, St. Petersburg. 
"Diffusion of silver and ionic conductivity in the solid electrolytes $\mathrm{Ag}_{8} \mathrm{HgS}_{2} \mathrm{I}_{6}$ and $\mathrm{Ag}_{6} \mathrm{I}_{4} \mathrm{WO}_{4}$," $\mathrm{Yu}$. G. Vlasov, Yu. E. Ermolenko, S. V. Glazunov, and V. V. Kolodnikov, Solid State Ionics, 34:157-160 (1989).

"Facts and problems related to the burial of radioactive wastes in seas adjoining the Russian Federation," Administration of the President of the Russian Federation, Moscow (1993).

"Process of obtaining oxide materials from nitric solutions by plasma method," Institute of Chemical Technology, Moscow.

"Plasma technology and equipment for conversion of uranium hexafluoride," A. V. Ivanov, V. P. Korobtsev, V. A. Seredenko, Y. N. Tumanov, and E. A. Filippov, Department "ChemConvers" of Russian Science Research Institute for Chemical Engineering, Moscow.

"Plasma process of hydrofluoric acid and disperse silica oxide by conversion of silicon tetrafluoride," A. V. Ivanov, V. P. Korobtsev, V. A. Seredenko, Y. N. Tumanov, and E. A. Filippov, Department "ChemConvers" of Russian Science Research Institute for Chemical Engineering, Moscow.

"Development of new processes for HLW treatment in induction furnaces with cooled pots, Draft," Institute of Chemical Technology, Moscow.

"Getting monodispersed microspherical particles in heavy media," Institute of Chemical Technology, Moscow.

"Technology and apparatus for solidification of radioactive wastes from nuclear fuel cycle by high temperature adsorption of metals with inorganic matrices," Department "KHIMCONVERS", Russian Research Institute for Chemical Technology, Moscow.

"Filtering element with constant operation characteristics," V. B. Krapukhin, V. I. Kareta, V. D. Zhurin, S. E. Grushevsky, and V. A. Lavrikov, Inst. Phys. Chem., Moscow.

"Continuous bulk Th(IV), Np(IV), and Pu(IV) oxalate crystallization kinetics," V. I. Kareta, S. E. Grushevsky, and V. B. Krapukhin, Inst. Phys. Chem., Moscow.

"A new process for volume reduction of radwaste drying and calcination of crystals," V. B. Krapukhin, Inst. Phys. Chem., Moscow. 


\section{Distribution}

No. of

Copies

Offsite

12 DOE/Office of Scientific and Technical Information

T. Fryberger

EM-542, Trevion II

U.S. Department of Energy

12800 Middlebrook Road

Germantown, MD 20874

Professor Gregory Choppin

Chemistry Department

Florida State University

Tallahassee, FL 32306-3006

Jack Watson

P.O. Box 2008

Oak Ridge National Laboratory

Oak Ridge, TN 37831

International Environmental Institute

S. D. Atkin, B5-30

S. A. Sande, B5-30

R. M. Schwenk, B5-30

\section{Onsite}

DOE Richland Operations Office

D. E. Trader, K8-50
No. of

Copies

\section{Pacific Northwest Laboratory}

L. Ballou, P7-18

E. M. Baroni, K1-74

D. J. Bradley, K8-41

G. H. Bryan, P7-25

C. L. Cooper (BWO)

L. R. Dodd, K8-31

N. M. Dowdy (BWO)

R. W. Forester, K6-88

S. C. Goheen, P8-08

S. W. Heaberlin, K8-34

B. M. Johnson, Jr., K1-78

M. L. Knotek, K1-48

W. W. Laity, K2-50

D. L. Nousen, K6-44

L. J. Sealock, Jr., K2-10

B. D. Shipp, K8-28

S. C. Slate, K1-19

G. M. Stokes, K1-74

J. L. Straalsund, B1-40

D. W. Wester, P7-25 (10)

Publishing Coordination

Technical Report Files (5) 